\begin{abstract}
UNIVERSIDADE DE SÃO PAULO
FACULDADE DE FILOSOFIA, LETRAS E CIÊNCIAS HUMANAS

Departamento de Letras Clássicas e Vernáculas

Programa de Pós-Graduação em Estudos Comparados de

Literaturas de Língua Portuguesa
\end{abstract}

MARLI MIYUKI KANO MIYASAKI

Ler e Ser - Encontro necessário para a compreensão da complexidade sígnica do Terceiro Milênio

(Edição revisada)

São Paulo

2010 
MARLI MIYUKI KANO MIYASAKI

\section{Ler e Ser - Encontro necessário para a compreensão da complexidade sígnica do Terceiro Milênio}

(Edição revisada)

Dissertação apresentada ao Programa de PósGraduação em Estudos Comparados de Literaturas de Língua Portuguesa da Faculdade de Filosofia, Letras e Ciências Humanas da Universidade de São Paulo para obtenção do título de Mestre em Letras. Orientador: Profa. Dra. Maria Zilda da Cunha

São Paulo

2010 


\section{FOLHA DE APROVAÇÃO}

Marli Miyuki Kano Miyasaki

Ler e Ser - Encontro necessário para a compreensão da complexidade sígnica do Terceiro milênio

Dissertação apresentada a Faculdade de Filosofia, Letras e Ciências Humanas da Universidade de São Paulo para obtenção do título de Mestre em Estudos Comparados de Literaturas de Língua Portuguesa.

Aprovado em:

\section{Banca Examinadora}

Prof. Dr.

Instituição:

Assinatura:

Prof. Dr.

Instituição:

Assinatura:

Prof. Dr.

Instituição:

Assinatura: 


\section{DEDICATÓRIA}

Dedico este trabalho à luz mais brilhante de minha vida: minha filha Clarice. 


\section{AGRADECIMENTOS}

Agradeço aos meus queridos pais - Júlio e Maria - que me ensinaram a viver e a ser a pessoa que sou hoje, às minhas divertidas irmãs - Márcia, Eunice e Mariana - que ensinaram o lado mágico das brincadeiras de criança, aos amigos verdadeiros que apesar do tempo e da distância sempre vibraram com as minhas vitórias e solidarizaram com as derrotas, a meu marido e amigo que me incentiva a cada empreitada, a todos os meus professores e alunos que ensinaram a ver o mundo com outros olhos, o "olhar de encantamento".

Não ousei citar nomes, pois são muitos e o esquecimento de alguém seria imperdoável, porém, uma pessoa, em especial, faço questão de registrar: Maria Zilda da Cunha. Mulher, Professora, Mãe, Amiga, Orientadora de pesquisa e de vida, acolheu-me tão lindamente que é difícil descrever. Obrigada pela oportunidade única de desenvolver este trabalho, da confiança em mim depositada desde o primeiro encontro.

Obrigada, Deus, por todas essas pessoas iluminadas fazerem parte de minha caminhada e torná-la muito mais feliz... 
O que o ser humano mais aspira é tornar-se um ser humano.

Parice Sispector 


\title{
RESUMO
}

\begin{abstract}
MIYASAKI, M.M.K. Ler e ser - Encontro necessário para a compreensão da complexidade sígnica do Terceiro Milênio. 2010, 151 f. Dissertação (Mestrado) - Faculdade de Filosofia, Letras e Ciências Humanas, Universidade de São Paulo, 2010.
\end{abstract}

Este trabalho se faz no bojo das relações que se tecem entre o homem, o mundo e as máquinas, no limiar do terceiro milênio, em que a profusão de mensagens e a hibridização de linguagens, cada vez mais estão presentes em nossas vidas a exigir habilidades de leitura e compreensão diferentes das exigidas em épocas passadas. Com o advento da era tecnológica, jovens e crianças são seduzidos pelos gadgets, e demonstram uma espécie de "reação" condicionada, sem consciência e sem reflexão, um olhar apático a tudo o que não esteja carregado de movimentos, flashes, sons, imagens. Considerando isso, refletiu-se sobre a complexidade sígnica em que estamos inseridos e o processo de transformação da cultura, do pensamento e das linguagens, que eclode com a revolução digital, promovendo novas articulações e relações de entendimento tanto no âmbito cognitivo quanto no afetivo, pessoal. A pesquisa visa, então, sinalizar caminhos para sensibilizar o ser humano.

Propomos nossa discussão, no âmbito e nas fronteiras da literatura e educação de jovens e crianças, pela via da leitura da 
literatura infantil e juvenil, da poesia, das artes em geral, visto que, são manifestações dotadas de qualidades capazes de suscitar novos olhares e provocar múltiplas semioses pela fruição e cognição. Compreendemos que este é o meio pelo qual o ser desta nossa era poderá transcender e voltar a experienciar um "olhar de encantamento", apreendendo e aprendendo a lidar com as emoções e informações necessárias para a formação de um ser humano mais justo, solidário, ético e agente transformador de si e da sociedade em que vive.

Palavras-chave: literatura infantil e juvenil, leitor, leitura, poesia, novas tecnologias 


\begin{abstract}
MIYASAKI, M.M.K. To read and to be - necessary meeting

to comprehend the signical complexity of the Third

Millennium. 2010, 151 f. Master's Thesis - Faculdade de Filosofia, Letras e Ciências Humanas, Universidade de São Paulo, 2010.
\end{abstract}

This work focuses on the interwoven relations between man, world and machines on the threshold of the Third Millennium, when the multiplicity of messages and the hybridization of languages are each time more present in our lives and demand new reading abilities. With the advent of the technological era, youngsters and children are seduced by the gadgets and show a kind of conditioned "reaction", without conscience or reflection, an apathetic view on everything that is not charged with movements, flashes, sounds, images. Considering this, we reflected on the signical complexity in which we are inserted and the process of changes in culture, thought and languages triggered by the digital revolution, which promoted new articulations and understanding of both the cognitive and affective ambits. So, this research aims to suggest ways to sensitize the human being. We propose our discussion within the frontiers of literature and children's/youngster's education, supporting that children's and juvenile literature, poetry and arts in general are expressions able to evoke new views and multiple semiosis through fruition and cognition. We understand this is the way through which 
our era's man will be able to transcend and to experience an enchanted view again, apprehending and learning how to manage the emotions and information needed to the formation of a fairer, more sympathetic and ethic human being, an agent who transforms himself and the society he lives in.

Keywords: children's and juvenile literature, reader, reading, poetry, new technologies 


\section{SUMÁRIO}

Introdução

1. Capítulo I

1.1 Complexidade e formação do ser 22

1.2 A transcendência e a educação 27

1.30 ser, a leitura e o leitor 38

\section{Capítulo II}

2.1 Alguns aspectos da literatura infantil e juvenil brasileira, seus

diálogos, seus leitores $\quad 48$

2.2 Em cena o leitor do terceiro milênio - O leitor navegador 57

2.3 Lendo a leitura na escola 62

\section{Capítulo III}

3.1 Poesia: breves reflexões 68

$\begin{array}{ll}3.2 \text { Signos em mutação } & 71\end{array}$

\subsection{Poesia e êxtase na imagem}

3.3.1 A gênese de "O Cântico dos Cânticos" de Ângela Lago 77

3.3.2 A obra - vários olhares 79

3.3.3 Olhar representativo 81

3.3.4 Olhar referencial 86

3.3.5 Olhar simbólico 90 


\subsection{Poesia e jogo}

3.4.1 Vivendo e... Tatianando

3.4.2 O jogo representativo

3.4.3 O jogo referencial 98

3.4.4 O jogo de sentidos

3.5 "O mundo é inquieto? A gente é mais" - a poesia virtual

- "Chá" de Sergio Capparelli e Ana Claudia Grusznski

3.5.1 Interação necessária

3.5.2 Poesia e virtualidade

3.5.3 Inquietudes virtuais

\section{Capítulo IV}

4.1 Vivências Poéticas

4.2 A escola

4.3 Os alunos

4.4 Projeto "Semeando Sonhos"

4.5 Projeto "Café com Poesia" 


\section{INTRODUÇÃO}

O ser dos humanos se forma ao longo da história, com as diversas leituras que faz - leitura do universo, dos fenômenos, das imagens, dos livros, do outro, de si próprio. Assim, a humanidade procura compreender o mundo, produz cultura e desenvolve-se. $O$ homem, pela via da linguagem, engendra-se na esfera da sociedade que comporta outros universos sígnicos, densos e complexos.

No mundo contemporâneo, nossas crianças e jovens assistem e participam de uma fantástica revolução tecnológica e, ao mesmo tempo, encontram-se inseridos em um universo em que a emoção, os sentimentos e a reflexão crítica são sobrepujados por valores mais convenientes a padrões que se estabelecem em função da hegemonia econômica, disso resulta um "descompasso" entre fatores básicos que constituem o ser: a vida social, a cognição e a emoção.

Edgar Morin (2002a, p.104) nos diz que:

o desenvolvimento de uma democracia cognitiva só é possível com uma reorganização do saber; e esta pede uma reforma do pensamento que permita não apenas isolar para conhecer, mas também ligar o que está isolado, e nela renasceriam, de uma nova maneira, as noções pulverizadas pelo esmagamento disciplinar: o ser humano, a natureza, o cosmo, a realidade.

Nesse sentido, o desafio da Educação está em fazer

reaparecer a unidade multidimensional da realidade antroposocial, articulando umas às outras essas ciências, hoje em 
dia dissociadas, que são a história, a sociologia, a economia, a psicologia, sem esquecer as ciências do imaginário, a ciência das crenças, pois eu estou entre os que pensam que as realidades imaginárias são extremamente importantes para conhecermos o ser humano.(MORIN, 1998,p.3)

Entendendo imaginário como uma "re-presentação incontornável, a faculdade da simbolização de onde todos os medos, todas as esperanças e seus frutos culturais jorram continuamente" (DURAND, 2004, p.117), dessa forma, compreendemos que através dele o ser humano, ao relacionar, discutir e refletir sobre as angústias, iras, paixões, desejos, acaba por fazer parte de uma rede simbólica que se faz presente em toda sua vida social, seja ela familiar, escolar, religiosa, econômica, política.

Imaginário e realidade são instâncias que cada ser acessa de forma diferente, dependendo de seu olhar, da formação cultural, social, política. As idas e vindas entre um campo e outro são necessárias para melhor compreensão de si e do mundo.

Consideramos literatura, de maneira ampla, como

todas as criações de toque poético, ficcional ou dramático em todos os níveis de uma sociedade, em todos os tipos de cultura, desde o que chamamos folclore, lenda, chiste, até as formas mais complexas e difíceis da produção escrita das grandes civilizações. (CÂNDIDO, 2004, p.174)

Sendo assim, ela simboliza o mundo e propicia uma forma especial e privilegiada de leituras múltiplas, desencadeando processos de regeneração de qualidades do sentir, provocando contínuos esforços da compreensão e da elaboração intelectiva para a apreensão de elementos 
do humano que nela se inscrevem. Cândido (2004, p.186) afirma que

A literatura corresponde a uma necessidade universal que deve ser satisfeita sob pena de mutilar a personalidade, porque pelo fato de dar forma aos sentimentos e à visão do mundo ela nos organiza, nos liberta do caos e portanto nos humaniza. Negar a fruição da literatura é mutilar a nossa humanidade.

A nosso ver, quanto mais diversificado for o contato com as leituras, entre essas, a do texto literário, melhor será a formação do ser humano do homem, uma vez que, segundo o mesmo autor (2004, p.175),

a literatura confirma e nega, propõe e denuncia, apóia e combate, fornecendo a possibilidade de vivermos dialeticamente os problemas. Por isso é indispensável tanto a literatura sancionada quanto a literatura proscrita; a que os poderes sugerem e a que nasce dos movimentos de negação do estado de coisas predominante.

A afirmação acima se torna importante, pois falar de leitura e literatura situadas historicamente em um mundo que se tece por múltiplos códigos e por diversas linguagens (verbais, imagéticas, digitais), requer lembrar que, além dos muros da escola, somos desafiados a viver, interagir e ler dialeticamente uma complexa e intrincada rede textual, o que vai requerer do homem contemporâneo um processo tenso e intenso de decodificação de mensagens. Decifrar sensível e intelectualmente essas mensagens e esse mundo significa também perceber e procurar inteligir os diferentes mecanismos de hibridização envolvidos neste processo sígnico. Gardin (1984, p.49) coloca que quanto melhor o homem estiver capacitado a ler este mesmo universo, 
melhor será sua própria relação de significação com este complexo de mensagens, e mais profunda sua possibilidade de intervir no conjunto de mensagens, transformando suas relações estruturais.

Verifica-se o fascínio de nossos jovens pelos novos suportes tecnológicos e pelo consumo cada vez mais feroz dos gadgets ${ }^{1}$. A palavra, a imagem e os textos hipermidiáticos parecem algo trivial, sem nenhuma perspectiva duradoura, visto que a cada instante surge uma novidade tecnológica. Dessa forma, a essência humana, o ser parece esvair-se na apatia do olhar que não consegue ver mais além, o encantamento se instala apenas no suporte utilizado e não nos projetos em que os textos são produzidos, desconsiderando, assim, o lado emotivo, afetivo, sensorial, mágico e poético dos mesmos e da vida.

Para Morin (2005) o ser humano produz, basicamente, duas linguagens: uma racional, empírica, prática, técnica (estado prosaico) e outra, simbólica, mítica, mágica (estado poético). Antonio Cândido diz que em todos os homens "perduram lado a lado o mágico e o lógico, fazendo ver que, ao menos sob este aspecto, as mentalidades de todos os homens têm a mesma base essencial." (1985, p.43)

Sendo assim, quando a valorização do racional e do lógico se faz exagerada, quando o lado mágico se perde, cumpre para resgatar a "base essencial" humana, recorrermos à poesia. Morin (2002b, p.20) afirma que:

\footnotetext{
Do inglês: geringonça, dispositivo. Gíria tecnológica que se refere a dispositivos eletrônicos portáteis (celulares, smartphones, tocadores MP3, entre outros) e ferramentas ou módulos que podem ser agregados num ambiente maior para facilitar ou incrementar os serviços oferecidos.
} 
A poesia dará à cultura das humanidades uma dimensão mais enriquecedora, pois ela mostra que a "verdadeira vida" não se encontra nas necessidades utilitárias às quais ninguém pode escapar, mas sim na auto-realização e na qualidade poética da existência.

Antônio Cândido (2004, p.175) coloca que nenhum ser humano

pode passar vinte e quatro horas sem mergulhar no universo da ficção e da poesia, a literatura [...] parece corresponder a uma necessidade universal, que precisa ser satisfeita e cuja satisfação constitui um direito.

O contexto em que nossos jovens estão inseridos favorece a satisfação básica universal a que Antonio Cândido se refere? De que forma o novo pensamento complexo da atualidade atua na formação humana deles? Essas são questões que nos moveram à realização deste trabalho, que abarca uma face de leituras analíticas e teóricas, de reflexão crítica e outra face que corresponde a um projeto experimental com leituras de textos literários com nossos alunos, ambas as faces articulam-se para dimensionar nossa praxis educadora, iluminada pela trajetória acadêmica.

Acreditamos que quanto mais apto o homem se tornar para compreender as manifestações de linguagem nas quais se engendra e pelas quais o contexto histórico se fala, mais apto ele estará para o enfrentamento da complexidade deste milênio e das transformações que esta era vem imprimindo na vida humana. Daí decorre a nossa hipótese: a leitura das linguagens que tecem os textos contemporâneos, sobretudo, a escrita e a imagética, agora, hibridizadas, o entendimento de seus 
mecanismos e a compreensão das interfaces criadas entre elas, são muito importantes para a formação de um leitor reflexivo, crítico e apto a experienciar uma "sensação de encantamento" para que possa também ter o seu poder criador e transformador (de si e do mundo) potencializados, enfim, humanizar o ser.

Consideramos humanização como

O processo que confirma no homem aqueles traços que reputamos essenciais, como o exercício da reflexão, a aquisição do saber, a boa disposição para com o próximo, o afinamento das emoções, a capacidade de penetrar nos problemas da vida, o senso da beleza, a percepção da complexidade do mundo e dos seres, o cultivo do humor. (CÂNDIDO, 2004,p.180)

A partir dessas premissas, nosso trabalho estuda algumas relações possíveis entre as leituras de diversas linguagens e a constituição do ser, pela via da literatura infantil e juvenil. Como diz Antonio Cândido (2004, p.180) "a literatura desenvolve em nós a quota de humanidade na medida em que nos torna mais compreensivos e abertos para a natureza, a sociedade, o semelhante."

É urgente nesse Terceiro Milênio, em meio à violência, à brutalidade, ao desrespeito, à indiferença, providenciarmos uma nova forma de nos relacionarmos com o mundo, com o outro, conosco; urge a re-descoberta de estratégias para equilibrar e harmonizar nosso ser e, conseqüentemente, as relações sociais em que nos inserimos. Pois, "assim como não é possível haver equilíbrio psíquico sem o sonho durante o sono, talvez não haja equilíbrio social sem a literatura". (CÂNDIDO, 2004, 


\section{p.175)}

Esses pressupostos orientaram projetos realizados em nossa escola de atuação, localizada na periferia de São Paulo, em que os alunos tiveram oportunidades de intensa interação com diversas leituras em sala de aula e depois puderam apresentar seus trabalhos, revelando seu potencial criador e transformador, serem reconhecidos por seu valor humano na dimensão do poético, ético e estético. Com isso, visamos a socializar a fruição da literatura, da poesia, da arte; romper as estratificações culturais construídas ao longo do tempo, como se, aos menos privilegiados, bastassem a cultura popular, marginal; oportunizar vivências diferenciadas do cotidiano da periferia (violência, descaso, esquecimento).

A literatura por ter uma função humanizadora, ou como diz Cândido (2002, p.77), ser capaz de "confirmar a humanidade do homem", ativa o que há de mais humano no homem, ou seja, "não corrompe nem edifica , mas, trazendo livremente em si o que chamamos o bem e o que chamamos o mal, humaniza em sentido profundo, porque faz viver." (CÂNDIDO, 2004, p.176)

Nosso trabalho está pautado no direito de todos à literatura, pois ela humaniza e atua na formação do ser, isso não quer dizer que todos transcenderão ou se tornarão melhores por causa dela, mas terão oportunidade de fazer escolhas. Só podemos escolher quando temos pelos menos duas opções, portanto, é condição básica proporcionar diferentes olhares e leituras aos nossos jovens e crianças. 
Assim, os exercícios de leituras, aqui trabalhados, abarcarão obras brasileiras de literatura infantil e juvenil.

Vale ressaltar: a) essas obras apresentam diálogos intertextuais, tramados em uma rede tecida no tempo e nas faces das linguagens do homem, em culturas distintas, em sociedades diversas, cujos registros perpetuam alguns aspectos (ideológicos, estéticos, sociais da práxis humana e de seus modos de produção de linguagem) pelo oral, pela escrita, pelas imagens, pela hipermídia - linguagem nascente da interface que se cria entre elas e que as irmana; b) apesar do nosso recorte, nossa perspectiva se faz orientada por princípios dos estudos comparados de literaturas de língua portuguesa, que propiciam um olhar capaz de reconhecer as obras como algo em movimento, porque nelas se inscrevem elementos de sua gênese, renovados nas absorções e nos diálogos, que nos levam a reconhecer a recepção como dinâmica, e a fruição estética menos idílica, posto que a obra nos obriga a questionar constantemente a realidade.

Dessa forma, selecionamos três obras com características distintas: uma com a predominância do código imagético (O Cântico dos cânticos de Ângela Lago), outra com a presença de código híbrido de verbo e imagem (Mandaliques de Tatiana Belinky) e ainda uma obra em hipermídia em que os códigos se tecem na interface do verbo e imagem - texto virtual (Chá de Sergio Capparelli e Ana Claudia Grusznski); projetos realizados em uma escola pública municipal: "Semeando Sonhos" e "Café com Poesia". Buscamos tecer relações e análises desses dois projetos à luz das 
primeiras partes deste trabalho. 


\title{
1. Capítulo I
}

\author{
"OKine e veja: o mais importante e bonito do mundo, é isto: que as pessoas \\ não estão sempre iguais, ainda não foram terminadas - mas que elas vão sempre \\ mudando. Ofinam e desafinam. Verdade maior." \\ Grande Sertão Oeredas - Guimarães Rosa
}

Neste capítulo pretendemos refletir acerca de algumas questões pertinentes à formação do ser humano, assunto que jamais se esgota dada sua complexidade. Cientes disso, traçamos algumas rotas que orientem nosso olhar para tal desafio.

\subsection{Complexidade e formação do ser}

Notamos, frequentemente, a convivência das palavras "constituição" e "construção" no que se refere à formação do ser. Para um uso mais preciso, em nosso trabalho, recorremos ao dicionário:

Construir 1. Dar estrutura a; edificar; fabricar; 2. Organizar; dispor, arquitetar; 3. Formar, conceber, elaborar.

Constituir 1 . Ser a base, a parte essencial, de; 2. Formar; compor.[...] 8. Consistir em; ser; representar, formar. ${ }^{2}$

O significado das duas acepções acima está bem próximo. No entanto, ao nos reportarmos às origens latinas ${ }^{3}$, verificamos significados mais distintos. Enquanto construir vem do latim construere (cum struo) e indica amontoar, acumular, empilhar, juntar; constituir tem sua origem em constituere (cum statuo) estabelecer juntamente, criar, formar, estar

2 FERREIRA, Aurélio Buarque de Holanda. Dicionário Aurélio Básico da Língua Portuguesa. São Paulo, Nova Fronteira, 1995.

3 TORRINHA, Francisco. Dicionário Latino Português. 6 a ed.Porto: Graficos Reunidos LDA, [194?]FARIA, Ernesto. Dicionário Escolar Latino-Português.6ªed. Rio de Janeiro:FAE, 1994. 
bem.

Dessa forma, "construir" implica em um aspecto mais solitário e menos solidário, em que parece não haver uma relação necessária do "outro". Já "constituir" indica um aspecto mais coletivo e, conseqüentemente, mais solidário, pois é necessário o trabalho conjunto para a formação, a essência, a base, questões essas inerentes ao ser.

Logo, o ser, em toda sua dinamicidade, vai se constituindo coletivamente e construindo individualmente, se formando no entrecruzamento de diversos saberes, nas relações complexas estabelecidas junto com o outro, consigo próprio e com o universo. Complexidade, aqui, não se reduz à complicação, mas àquilo que se tece em conjunto, com vários fios diferentes; no latim, complexere tem também como acepção abraçar, algo que nos remete a união, a conjunto.

O ser humano, para Morin (2002a, p.40), "nos é revelado em sua complexidade: ser ao mesmo tempo, totalmente biológico e totalmente cultural", o nascimento, nestes termos, já garante ao homem sua existência, porém existir biofisicamente apenas, não basta. Nenhum homem é capaz de viver isoladamente, já que é um ser intrinsecamente social e cultural, a todo instante interage com o mundo e com o outro; tais contatos se estabelecem ora de forma harmoniosa (afinam), ora conflituosa (desafinam), assim as mudanças ocorrem tanto nos homens quanto no mundo.

Como diz Guimarães Rosa: "o mais importante e bonito do mundo, é isto: que as pessoas não estão sempre iguais, ainda não foram 
terminadas - mas que elas vão sempre mudando. ${ }^{4}$, essas mudanças não são apenas as biofísicas (estas são inevitáveis), mas, sobretudo, as mudanças do ser dos humanos, que vai se constituindo através das vivências ao longo de seu existir.

O homem, por sua incompletude, busca resgatar a comunhão primordial entre o "eu" e o mundo, ansiando ser completo. Tal busca é sempre uma renovação, uma transformação na relação e na condição de ser/estar no mundo,

Quanto mais a fundo sondarmos o nosso espírito, mais a fundo sondamos o universo. A partir daí, torna-se-nos necessário ligar o conhecimento do espírito cognoscente. (MORIN, 1986, p.201)

Quanto melhor nos entendermos, melhor entenderemos o Universo, pois ambos constituem uma rede organizacional intrincada de saberes e percepções. Chamamos de rede organizacional as relações e interrelações decorrentes de diferentes saberes, caso os mesmos não estejam organizados serão apenas informações/dados esparsos que podem vir a ser utilizados, se acionados. Trata-se de uma rede de inesgotável possibilidade e, conseqüentemente, de transformação, já que os novos saberes e percepções se ligam aos já adquiridos.

Morin afirma ser necessária uma concepção complexa do sujeito, pois cada ser, baseado em suas intenções e desejos, relaciona e organiza

\footnotetext{
${ }^{4}$ ROSA, João Guimarães. Grande sertão: Veredas. 3aed.Rio de Janeiro:Editora José Olympio, 1963.
} 
a própria "rede" de forma distinta,

Precisa-se de uma reconstrução [noção de sujeito], precisase das noções de autonomia/dependência; da noção de individualidade, da noção de autoprodução, da concepção de um elo recorrente, onde estejam, ao mesmo tempo, o produto e o produtor - é preciso associar noções antagônicas, como o princípio de inclusão e exclusão. (2002a, p.128)

O princípio da inclusão, segundo o mesmo autor, é quando se pode inserir um nós dentro do Eu, há dentro de mim um pouco do outro ou dos outros, formando um coletivo. O da exclusão indica que o Eu é único para cada um, ninguém pode dizer em meu lugar; embora haja "outros" em mim, a individualidade é preservada e mais do que isso: necessária. Portanto, o "sujeito é potencialmente outro, sendo ao mesmo tempo, ele mesmo. É porque o sujeito traz em si mesmo a alteridade, que ele pode comunicar-se com outrem". (MORIN, 2002a, p.123)

A ética humana, sob essa perspectiva, nasce da compreensão de que em cada um, há um pouco do outro, permitindo

considerar a outro não apenas como ego alter, um outro indivíduo sujeito, mas também como alter ego, um outro eu mesmo, com quem me comunico, simpatizo, comungo. (MORIN, 2002a, p.123)

Logo, "compreender o humano é compreender sua unidade na diversidade, sua diversidade na unidade. É preciso conceber a unidade do múltiplo, a multiplicidade do uno." (MORIN, 2000, p.55)

Portanto, há a constituição do ser universal, a unidade humana (valores e questões universais), mas há também o ser único, as diversidades individuais. Pois, "todo o ser, mesmo aquele fechado na mais 
banal das vidas, constitui ele próprio um cosmo." (MORIN, 2002a, p.50)

O "cosmo" que o autor coloca pode ser associado à "rede organizacional" que já mencionamos no início do capítulo, um elemento vivo, pulsante que está em constante movimento e transformação.

Em cada ser há um turbilhão de informações e emoções, aparentemente em meio caótico, que precisa ser organizado para que o equilíbrio seja instaurado. Um equilíbrio provisório, pois em seguida vem um novo ponto de desequilíbrio. É sempre desejável que este processo (desequilíbrio / equilíbrio) seja constante, pois é dessa forma que a rede organizacional se estende e se renova.

Em uma perspectiva da complexidade, a noção de sujeito se torna holística, ou seja, a junção ou convivência de emoção, razão, desequilíbrio, equilíbrio, imaginário, realidade. Essas diferentes formas se relacionam intensamente e são necessárias para a formação do ser humano.

Sobre essa questão, Morin (1973, p.128) esclarece:

o imaginário tem a sua realidade própria, e aquilo a que chamamos realidade está sempre embebido de afetividade e de imaginário, que o sujeito tem sempre uma existência objetiva, mas que a objetividade só pode ser concebida por um sujeito. Isto para dizer que não existe, por um lado, o reino da objetividade e do real, que se poderia isolar totalmente da subjetividade e do imaginário, nem, por outro lado, as miragens do imaginário e da subjetividade. Existe oposição entre estes termos, mas eles são inevitavelmente abertos um para o outro de forma complexa, quer dizer, são simultaneamente complementares, concorrenciais e antagonistas. 
Portanto, conceitos como: objetivo, subjetivo, real, imaginário, razão, emoção não podem mais ser tratados como "isto ou aquilo", em uma acepção fechada, de exclusão, eles devem ser vistos à luz de uma concepção mais aberta e de inclusão, como "isto e aquilo", em tessitura, algo tecido em conjunto, cujos constituintes heterogêneos e contraditórios encontram-se inseparavelmente associados - no dizer de Morin (1991, p.17-18) - complexus.

\subsection{A transcendência e a educação}

O termo "transcendência" é importante em nosso trabalho. Vale ressaltar, no entanto, que não pretendemos discutir questões concernentes a correntes filosóficas ou metafísicas. Entendemos, na esteira de Ferreira (1995), que "transcender" significa ultrapassar, transformar, ser superior, o que transcende os limites da experiência possível.

Para que haja a transcendência do ser, é fundamental que os conhecimentos se inter-relacionem com outros pontos da "rede organizacional" individual e social, pois a consubstanciação de um conhecimento com outro, pode gerar novo conhecimento, então, o sujeito toma consciência de que tem o poder de superar, de criar.

Este processo de transformação não tem fim, é um constante organizar e reorganizar. O homem transcende quando confere um sentido ao ser, quando toma consciência de suas potencialidades para interferir no rumo de seu próprio caminho. Logo, em meio a uma cadeia dinâmica, a 
transcendência pode ocorrer a qualquer momento da vida. Esse processo não é automático, nem determinista, posto que, existem inúmeras variáveis que podem favorecer, ou não, o indivíduo; "os seres possuem múltiplas personalidades e tudo depende dos acontecimentos, dos acidentes que ocorrem com eles e que podem liberar alguns deles." (MORIN, 2005, p.61)

Seguir um caminho ou outro, ser de um jeito ou de outro são decisões individuais, no entanto, é necessário considerar o fato de que fatores externos, inexoravelmente, contribuem para as escolhas do sujeito, Cândido (1985, p.36) afirma que "mesmo quando pensamos ser nós mesmos, somos público, pertencemos a uma massa cujas reações obedecem a condicionantes do momento e do meio". Não há nada que determine, com exatidão, uma conduta. Contudo, é importante salientar que não estão isentas desse processo as instituições de domínio público (escola, por exemplo) e privado (família, religião); a cada uma delas cabe a responsabilidade de cumprir importante papel na formação dos indivíduos.

Como já colocado, o ser é formado por diversos fatores e circunstâncias psicossocioculturais. Portanto, tendo em mente o jovem contemporâneo, vale lembrar a responsabilidade da educação em:

dar aos estudantes, aos adolescentes que vão enfrentar o mundo do Terceiro Milênio - o seu mundo - uma cultura Isto é, aquilo que lhes permitirá articular, religar, contextualizar, isto é, situar em um contexto, e se possível globalizar, colocar em um conjunto os conhecimentos que eles adquirirem. (MORIN, 1998, p.01) 
Em especial, neste mundo de informações fragmentadas, é necessário levar em consideração que

o pensamento mutilante, isto é, o pensamento que se engana, não porque não tem informação suficiente mas porque não é capaz de ordenar as informações e os saberes, é um pensamento que conduz a ações mutilantes. (MORIN, 1984, p.14)

Ao articular os conhecimentos, contextualizar e valorizar os diferentes saberes, potencializa-se o desenvolvimento e a transcendência do ser, tal qual o Mito da Caverna, de Platão, se não formos capazes de organizarmos as informações e vermos o todo, seremos fadados ao engano, o nosso olhar se limita na parede.

Em Amor, poesia, sabedoria, Edgar Morin (2005,p.38) comenta:

em nossa cultura ocidental, tanto a poesia quanto a cultura
humanista foram relegadas. Relegadas no lazer e no
divertimento, relegadas por adolescentes e por mulheres,
transformaram-se, de algum modo, num elemento
inferiorizado em relação à prosa da vida.

Verifica-se que o autor aponta para a fenda, uma separação construída entre o lado prosaico e o lado poético da vida na cultura ocidental; esse sentido abrangente que ele confere à poesia e à prosa, por questões metodológicas, torna-se, para nós, muito precioso. A poesia é o lado subjetivo, humano, afetivo, mágico; a prosa, o objetivo, o científico, o utilitário, o conceito.

Entre a poesia e a prosa, nós entendemos existir vários meandros 
engendrando múltiplas relações. Porém, é interessante evidenciar a desconsideração que ocorre com o lado poético do homem, enquanto o lado prosaico é supervalorizado.

Em face destas reflexões, entendemos ser possível a articulação entre essas duas instâncias da vida. Ambas podem ser valorizadas em esferas que não compartimentem os saberes e os conhecimentos em uma ou outra. Afinal, numa perspectiva da complexidade os saberes se entrecruzam e formam outras diversas dimensões.

Não é mais possível conceber o universo apenas de forma concreta e objetiva, há instâncias do imaginário, da magia nas explicações da realidade. Afinal, a própria palavra universo pede um tratamento poético: Uni - Verso. Versos que se combinam e tecem os mistérios do mundo.

Quanto ao conhecimento, para a nova geração, há pelo menos uma vantagem e uma desvantagem.

A desvantagem está no já comentado fato de que na cultura ocidental a poesia e a cultura humanista foram relegadas a um elemento inferior em relação à face prosaica da vida.

A vantagem está nas vias de regeneração de uma rica e vasta cultura humanista, artístico-literária, portanto, uma rica e vasta reflexão da condição humana.

Nosso trabalho se faz por rotas que viabilizem o resgate $e$ valorização desse conhecimento humano que foi desprezado em função das concepções racionalistas que presidem o pensamento moderno.

Ao fim e ao cabo, a literatura, a poesia, as artes em geral, são 
experiências de vida que podem contribuir, especialmente para o adolescente em busca de si mesmo, com uma autoconsciência, uma consciência de si, da relação com o outro, de suas próprias paixões, dos próprios movimentos de sua alma... (MORIN, 2002b, p.353)

No entrecruzamento das experiências prosaicas e poéticas se tecem os ideais que consubstanciam a constituição e transcendência do ser.

Vivermos, constantemente, em qualquer dos extremos seria alienação. Pois o homem para se sentir pleno, necessita não só do lado prosaico, o real, o concreto, mas também do lado poético, o lado mágico, maravilhoso. Como diz Antonio Cândido (2004, p.174) "assim como todos sonham todas as noites, ninguém é capaz de passar as vinte e quatro horas do dia sem alguns momentos de entrega ao universo fabulado."

O esforço da educação reside em oportunizar diversas leituras, principalmente aos menos privilegiados que tem pouco e difícil acesso à literatura diversificada, portanto,

A luta pelos direitos humanos abrange a luta por um estado de coisas em que todos possam ter acesso aos diferentes níveis da cultura. A distinção entre cultura popular e cultura erudita não deve servir para justificar e manter uma separação iníqua, como se do ponto de vista cultural a sociedade fosse dividida em esferas incomunicáveis, dando lugar a dois tipos incomunicáveis de fruidores. Uma sociedade justa pressupõe o respeito dos direitos humanos, e a fruição da arte e da literatura em todas as modalidades e em todos os níveis é um direito inalienável. (CÂNDIDO, 2004, p. 191)

Vale ressaltar que a educação não se restringe ao ambiente escolar, é um compromisso de todos para com o conhecimento e para com a formação social, cultural e psíquica do ser humano. Além disso, é 
importante lembrar que o conhecimento articulado e compartilhado possibilita melhores condições para efetivar reflexões e condutas mais éticas no sentido de conduzir o mundo, a sociedade e projetar o ser humano.

$O$ ato de educar não se limita à transmissão de informações e de conceitos científicos e lógicos, uma vez que deve promover a formação integral do ser, incluindo as relações consigo próprio e com o outro. Logo, tal ato vincula-se também à responsabilidade da constituição e resgate do ser ético,

educar é preparar para vida, portanto, é importante ajudar o jovem a obter maior clareza de mente e enriquecimento da sensibilidade. Além desse aspecto essencial, o desenvolvimento da leitura entre as crianças resultará em seu enriquecimento progressivo no campo dos valores morais, no campo racional, no da cultura e da língua. (GÓES, 1984, p.24)

Os jovens podem aprender a lidar com os conflitos subjetivos e inter-subjetivos, por meio, principalmente, da literatura e das artes em geral, pois essas vitalizam nosso ser, fazem-nos abstrair da dura e fria realidade que nos cerca, elementos que nos permitam vivenciar circunstâncias diversas da rotina do dia-a-dia.

Marisa Lajolo (2001a, p.106) nos diz que:

é à Literatura, como linguagem e como instituição, que se confiam os diferentes imaginários, as diferentes sensibilidades, valores e comportamentos através dos quais uma sociedade expressa e discute, simbolicamente, seus impasses, seus desejos, suas utopias. 
Cândido (2004, p.176) afirma que

Há conflito entre a idéia convencional de uma literatura que eleva e edifica (segundo os padrões oficiais) e a sua poderosa força indiscriminada de iniciação na vida, com uma variada complexidade nem sempre desejada pelos educadores. Ela não corrompe nem edifica, portanto; mas, trazendo livremente em si o que chamamos o bem e o que chamamos o mal, humaniza em sentido profundo, porque faz viver.

Portanto, vivenciar situações artístico-literárias humaniza o ser, no sentido mais profundo, ao lidar com o que conhecemos como o bem ou o mal, não podemos prever o que será despertado dentro de cada um, porém trata-se de um direito de todos, portanto, torna-se indispensável sua fruição.

O diálogo entre o real e o imaginário aguça os sentidos mais profundos do ser humano, suas dores, angústias, alegrias, além do sentido ético-estético que se apresenta nesse processo.

Ético quando se trata de pensamento capaz de alicerçar condutas mais razoáveis e conseqüentes, que represente relações estabelecidas entre as personagens, os valores universais e as possibilidades do acerto e do erro. A esse respeito, Morin (2002a, p.48) afirma que os livros

constituem "experiências de verdade", quando nos desvendam e configuram uma verdade ignorada, escondida, profunda, informe, que trazemos em nós, o que nos proporciona o duplo encantamento da descoberta de uma verdade exterior a nós, que se acopla a nossa verdade, incorpora-se a ela e torna-se a nossa verdade.

Quando essa verdade exterior conecta-se à nossa rede 
organizacional, engendramos um novo conhecimento. Aprendemos com a vivência do outro.

O contato com o Estético, não é meramente um contato com a beleza visual-concreta, mas, sobretudo, o exercício da sensibilidade e da possibilidade de se obter a consciência de que a obra passa por processos internos (do artista consigo próprio) e externos (do artista com o outro, com o mundo) para se chegar à sua concreção. A obra literária está em diálogo permanente com o homem e a sociedade.

A contemplação estética, portanto, não é mera sensação, ou observação aleatória, é também investigativa. No dizer de Santaella (1992, p.181):

A contemplação estética não é contemplação beatificada ou abobada. Ao contrário, é contemplação ativa. Há um fisgamento, algo que nos atrai. Há um entretenimento, algo que nos cativa. Mas há também uma razão que borbulha junto com o sentimento. A suspensão do policiamento da racionalidade, a pura inocência dos sentidos é fundamental ao estado mental estético, mas isso não significa que a razão criativa não entre também em operação para compreender o sentimento.

Ainda segundo Santaella (1992), o ser humano desenvolve-se tanto sensível quanto intelectualmente através do olhar estético.

Nesse sentido, um processo de re-humanização do homem passa pela procura de algo de humano que foi se perdendo em favor do tecnicismo e dos estímulos condicionados. Para Schiller (1989,p.26): 
A utilidade é o grande ídolo do tempo; quer ser servida por todas as forças e cultuada por todos os talentos. Nesta balança grosseira, o mérito espiritual da arte nada pesa, e ela, roubada de todo estímulo, desaparece do ruidoso mercado do século. Até o espírito de investigação filosófica arranca, uma a uma, as províncias da imaginação, e as fronteiras da arte vão-se estreitando à medida que a ciência amplia as suas.

A valorização extremada do que é útil fez com que a arte e as ciências humanas perdessem importância, porém para o homem , de fato, ser livre "é necessário caminhar através do estético" (SCHILLER, 1989, p.26), o autor afirma ainda que o homem pode passar por três estados: o físico, o estético e o moral. "No estado físico o homem apenas sofre o poder da natureza, liberta-se deste poder no estado estético, e o domina no estado moral." (SCHILLER, 1989, p.123)

Hoje, mais do que nunca, a ética da compreensão humana se torna imprescindível, uma vez que "constitui uma exigência chave de nossos tempos de incompreensão generalizada." (MORIN, 2002a, p.51) Incompreensão gerada pelo isolamento cada vez maior entre as pessoas, entre os saberes, entre os conhecimentos. Incompreensão que gera ódio e violência. A sociedade cobra cada vez mais a perfeição. As pessoas, em permanente vigília, colocam-se alertas quase o tempo todo, poucos são os momentos de devaneio e de relaxamento, ocasionando cansaço físico e psicológico. Situações tensas de convívio ocasionam o que temos verificado nos noticiários nacionais e internacionais: uma crescente onda de violência (para si e para outrem). Embora as causas sejam incompreensíveis, aprender a lidar com os conflitos (internos ou externos) 
pode minimizar tais fatos.

Nessa ordem de ideias, retomar a "ética da compreensão humana", torna-se extremamente necessário, posto que "a linguagem humana não responde apenas a necessidades práticas e utilitárias", ela responde também "a necessidades de comunicação afetiva". (MORIN, 2005, p. 53)

Considerando afetividade como o lidar com os sentimentos, tanto bons (amor, solidariedade, respeito) quanto ruins (ódio, rancor, raiva), importa recuperar a que a literatura e a arte em geral são fontes de sensibilização e, portanto, permitem-nos avaliar, julgar, criticar, perguntar, dialogar com esses antagonismos. Isto potencializa formas de compreensão, por conseguinte, traz possibilidades de renovar nossas próprias ações e reações em bases mais conseqüentes diante de determinadas circunstâncias.

Para tanto, faz-se necessária a aprendizagem de um movimento capaz de promover um distanciamento, uma capacidade de objetivação e de aceitação a fim de se estabelecer uma auto-ética, em outras palavras , uma ética para si e para o outro, que "consiste em se ver como objeto, sabendo integralmente que se é sujeito, em poder descobrir-se, examinar-se." (MORIN, 2005, p.64)

Se, como Morin disse, há um "cosmo" dentro de cada um de nós, precisamos estar preparados para ordenar e reordenar as partes. Somente dessa forma, será possível civilizar as relações humanas, resgatar o ser dos humanos. Para isso três condições são essenciais: a compreensão, o respeito e a solidariedade. 
A compreensão de si, dos seus limites, dos medos, iras, amores, enfim, compreender o que é, o que se tem além do corpo físico; compreender que um pouco do que há em mim há no outro também e vice-versa.

O respeito por si mesmo e pelo outro. Talvez, em algumas circunstâncias, possa não compreender o que o outro seja, mas há que se respeitar a individualidade, as diferenças, a diversidade em seu sentido mais amplo. A solidariedade incide no reconhecimento do outro, sentir a dor do outro como se fosse a nossa.

Não podemos viver isolados, nós não nos bastamos. Precisamos sempre do outro, precisamos reconhecê-lo e sermos reconhecidos por ele. O homem, por natureza, é um ser que busca interação, inter-relação e "a beleza do amor reside na interpenetração da verdade do outro em si, implica encontrar sua verdade através da alteridade." (MORIN, 2005, p.31)

A escola é um dos espaços em que se desenvolvem meios pelos quais é possível intermediar ou revelar situações em que o aluno possa adquirir conhecimentos, dentre esses, o de conhecer, ou de reconhecer, o amor, a dor, a justiça, a injustiça.

Nesse sentido, Said (2005, p.53) assinala a tarefa do intelectual como a de "universalizar de forma explícita os conflitos e as crises, dar maior alcance humano à dor de um determinado povo ou nação, associar essa experiência ao sofrimento de outros". Para que dessa forma, os jovens possam experienciar uma perspectiva diferente: ver e sentir do seu 
ponto-de-vista e também se colocar no lugar do outro, esse exercício de distanciamento e aproximação do olhar se torna importante, pois faz compreender que sou todo e parte ao mesmo tempo. Sou um ser, um todo único, mas ao mesmo tempo sou uma pequena parte de uma estrutura maior; por compreender isso, respeito o outro que também é todo e parte; quando tenho consciência disso, solidarizo-me com o outro que é como eu, todo e parte e, igualmente, participa dessa mesma estrutura maior chamada: Humanidade.

\section{$1.30 \mathrm{ser}$, a leitura e o leitor}

No mundo contemporâneo, a hibridização e os entrecruzamentos das linguagens visuais, verbais, sonoras, sensoriais, entre tantas outras alteram as formas do texto impresso e as formas do ler. Fato que nos leva a buscar compreender o processo que se dá, sobretudo, entre texto e leitor considerando as modificações que ocorrem no universo da leitura. Para tanto, buscamos a visão de alguns autores.

Martins (1984) coloca que a decodificação e a compreensão são condições necessárias à leitura, pois decodificar sem compreender é inútil e o inverso, impossível. Sole (1998, p.24) complementa que para engendrar o processo de leitura do verbal

É necessário dominar as habilidades de decodificação e aprender as distintas estratégias que levam à compreensão. Também se supõe que o leitor seja um processador ativo do texto, e que a leitura seja um processo constante de emissão e verificação de hipóteses que levam à construção da compreensão do texto e do controle desta compreensão 
de comprovação de que a compreensão realmente ocorre.

Já Kleiman (1989) afirma que as estratégias cognitivas do leitor e os níveis de conhecimento são acionados para construção do sentido do texto:

As estratégias cognitivas regem os comportamentos automáticos, inconscientes do leitor, e o seu conjunto serve essencialmente para construir a coerência local do texto, isto é, aquelas relações coesivas que se estabelecem entre elementos sucessivos, seqüenciais no texto (p.50)

É mediante a interação de diversos níveis de conhecimento, como o conhecimento lingüístico, o textual, o conhecimento de mundo, que o leitor consegue construir o sentido do texto. E porque o leitor utiliza justamente diversos níveis de conhecimento que interagem entre si, a leitura é considerada um processo interativo. (p.13)

Notamos que a abordagem de cada autora traz elementos importantes do processo dinâmico e complexo da leitura: decodificação, compreensão, verificação de hipóteses, estratégias cognitivas, percepção, conhecimento prévio, controle.

Dessa forma, a compreensão textual é um processo que pode ser diferenciado para cada leitor num mesmo momento ou diferenciado para o mesmo leitor em momentos diversos, dependendo dos conhecimentos adquiridos e acionados.

O sentido da leitura incide em constante escolha e decisão daquilo que nos satisfaz, em dado momento, por vezes, tornando-nos melhores, acrescentando algo e tornando-nos mais competentes para novas abordagens. Dessa forma, gera-se um novo conhecimento que em nova leitura retorna numa espiral e complexifica-se, tornando-se subsídio para 
outras escolhas e novas decisões ao longo da vida do leitor.

O conhecimento possibilita o ser humano viver, efetivamente, a vida, tentar entendê-la sempre um pouco mais e descobrir que nada é absoluto e que a incerteza e o aleatório estarão presentes a qualquer momento, faz com que compreendamos a mutabilidade constante do mundo. Ao termos consciência

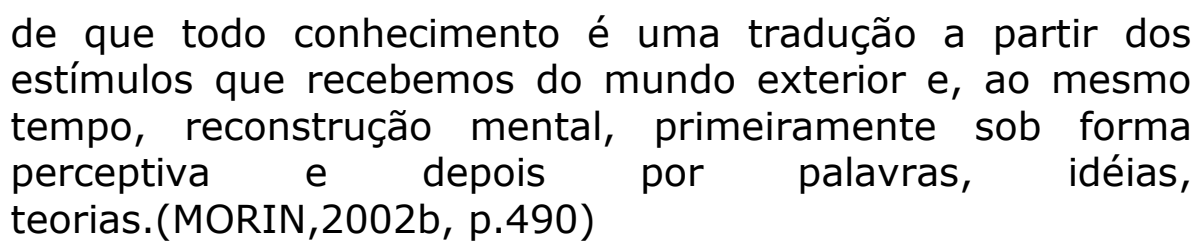

entendemos que o conhecimento se dará somente se houver um duplo movimento: de fora para dentro (estímulos exteriores) e dentro de si (reorganização interna dos conceitos e saberes já adquiridos com as novas aquisições). Nesse sentido, a reorganização será acionada se houver novas informações a serem incorporadas. Yves Bonnefoy ${ }^{5}$ afirma que "o adolescente espera os signos relativos à gravidade e ao mistério da vida, muito mais do que uma literatura qualificada de "ao alcance da juventude."

Ora, se está "ao alcance" é porque não há obstáculos a transpor, não há novidade alguma. Então para quê ler algo que não acrescenta nada, que não traz desafios?

Nesse sentido, Sole (1998) conceitua como a $3^{a}$ idéia construtivista - processos de andaimes, em que os desafios que o leitor deve ser capaz

\footnotetext{
${ }^{5}$ In: MORIN, Edgar. A religação dos sabers: o desafio do século XXI. Trad.e notas Flávia Nascimento. $3^{\mathrm{a}}$ ed.Rio de Janeiro, Bertrand Brasil, 2002, p.353
} 
de resolver estejam, como motivação, um pouco além, assim como os andaimes estão localizados um pouco acima do edifício para que a construção se dê de forma efetiva.

O conhecimento engendra inúmeras possibilidades de sentidos que a "leitura" pode trazer. Quanto mais aprendemos, mais recursos teremos para enveredarmo-nos pelos diversos textos (verbais ou não) e encontrarmos novos caminhos, novos sentidos.

A chave para compreender o universo está em nossa capacidade de lê-los adequadamente e dominar suas combinações e, assim, aprender a dar vida a alguma parte daquele texto colossal, numa imitação de nosso Criador. (MANGUEL, 1997, p.21)

O sentido da leitura está, justamente, na possibilidade da articulação da leitura de sentidos diversos, construindo assim o conhecimento de cada um. Este processo se torna cada vez mais complexo, visto que, a cada dia surgem novos "fios", novos entrelaçamentos para compor o texto/tecido de inesgotável possibilidade e significação. Afinal, "a descoberta de novos suportes materiais do sentido introduz correções nas concepções do sentido e pode até acarretar uma reestruturação fundamental destas concepções." (BAKHTIN, 1992, p.367)

Temos visto, historicamente, que os meios de produção de linguagem alteram os processos de escritura e leitura. Com o advento da era midiática, a hibribização das linguagens e o surgimento de novos 
suportes, como telas de t.v., computador, entre outros, o leitor ativa o processo de leitura de forma diferenciada, já que a hipermídia, por exemplo, exige um outro movimento de leitura na tela: não-linear e composta de hiperlinques ou rotas de navegação.

Com a celeridade das transformações promovidas pelas novas tecnologias, o homem parece dispor de menos sensibilidade, atenção e reflexão, agindo de forma apressada, robotizada, sobretudo, os jovens e crianças, diante de telas de T.V., do computador, de vídeo games, de celulares, demonstram uma espécie de "reação" condicionada, sem consciência, sem reflexão; causas, talvez, da incompreensão dos diversos "fios" entremeados em nossas vidas.

Torna-se urgente, segundo Coelho (1991, p.261),

Que as novas gerações descubram a leitura estimuladora ou criadora e através dela alcancem a formação humanística (Literatura, História, Filosofia, Ciências Humanas e Artes em geral) que lhes dará a base cultural indispensável para serem no futuro os criadores de programas que a nova Era exigir. E não os programadores obsessivos em que forçosamente se transformarão em pouco tempo, "robotizados" pela automação exigida para o uso dos computadores.

Discutir relações que possam ser estabelecidas entre o ato de ler e a constituição do ser mais humano do terceiro milênio é pauta importante de estudos atuais. Propomos fazê-lo pelas vias da literatura infantil e juvenil e entendemos a importância da formação de um ser que esteja habilitado a ler, efetivamente, códigos verbais e não-verbais, para que a experiência coletiva das artes se torne sua experiência individual, 
aumentando sua bagagem cultural que permitirá um olhar mais atento, crítico, e ainda assim, sensível e encantado com as diversas possibilidades de significação dos diferentes textos que compõem a sociedade e nosso universo.

As questões que emergem das relações possíveis do homem com a arte, as inter-influências que ocorrem, sua relação com as dimensões de estar e viver no mundo, as possibilidades de significação e re-significação dessas dimensões para a nossa constituição e nossa participação na sociedade são questões que há algum tempo nos incomodam e foram elas que nos moveram a este percurso de estudo.

As questões apontadas acima encontram consonância no pensamento de que

\begin{abstract}
A literatura é uma parte inalienável da cultura, sendo impossível compreendê-la fora do contexto global da cultura numa dada época. Não se pode separar a literatura do resto da cultura e, passando por cima da cultura, relacioná-la diretamente com os fatores sócio-econômicos, como é prática corrente. Esses fatores influenciam a cultura e somente através desta, e junto com ela, influenciam a literatura. (BAKHTIN, 1992, p.362)
\end{abstract}

Walter Benjamin (1994), no célebre texto "O autor como produtor", também destaca o fato de a evolução da técnica e das formas de produção interferirem significativamente na própria natureza da obra artística. Sendo assim, pode-se afirmar que as produções científicas, tecnológicas e artísticas vêm transformando a cultura, o pensamento, as linguagens e as relações sociais. Um movimento que há algum tempo 
sinaliza radicais mudanças eclodindo com a revolução digital que providenciou a mistura de muitos códigos e linguagens a que a criança, o adolescente ou o adulto para acessar precisam se rearticular para novas leituras e para a construção de novos sentidos.

A leitura desses novos códigos exige muita rapidez. Para um leitor que não esteja adequadamente instrumentalizado, a velocidade, a profusão de mensagens instantâneas não permitem que haja tempo para a "reflexão" e pensar em outras possibilidades de ação.

Não se trata de culpar esse "novo mundo", trata-se de discutir como preparar e formar nossos jovens para essa nova realidade. Como fazer com que eles dialoguem com esses novos códigos de forma que sejam subsídios para a constituição de um ser mais humano.

O diálogo somente pode ocorrer, se as partes envolvidas tiverem pleno conhecimento de si, dos outros e do contexto em que estão inseridos.

Para ser/estar no mundo temos a necessidade de conhecê-lo e, para isso, somos exigidos, sempre a participar do seu processo de produção de significados e intervir no seu movimento de significação, ler-significando. ${ }^{6}$

Instrumentalizar o jovem significa dar a ele subsídios não só para entender o mundo, mas também para ter a possibilidade de intervenção e transformação do meio em que se vive. É também ajudá-lo a

Se reconhecer em sua própria humanidade, situando-a no mundo e assumindo-a. Tudo isso deve contribuir à formação

\footnotetext{
6 GARDIN, Carlos e OLIVEIRA, Maria Rosa Duarte. "Semiótica e Educação". In: Cadernos PUC Arte \&Linguagem. № 14, p.49.
} 
da consciência humanista e ética de pertencer à humanidade, que deve ser completada pela consciência do caráter de matiz que tem a Terra para a vida e, por sua vez, daquele que tem a vida para a humanidade. (MORIN, 2002b, p.19)

Por meio da leitura, especificamente da leitura do texto literário, pode-se alcançar a consciência de que cada ser encerra em si mesmo todo um universo particular, mas que, ao mesmo tempo, também faz parte de outro universo: o coletivo, compartilhado por todos os outros seres.

Morin (1998, p.04) diz:

o futuro é absolutamente incerto, é preciso pensar com e na incerteza. Mas não numa incerteza absoluta, porque a verdade é que navegamos em um oceano de incertezas, através de arquipélagos de certezas locais.

Essas certezas locais são o sentido da vida, afinal, como poderíamos viver sem ter um objetivo, algo que nos mova, que faça valer a pena estar e ser vivo. Nelly Novaes Coelho (1982, p.35) afirma: "hoje, como no passado, a tarefa mais importante e também mais difícil na criação de uma criança é ajudá-la a encontrar significado na vida."

Esse significado pode ser construído através do caráter organizador da obra literária, como diz Cândido (2004, p.177):

Quer percebamos claramente ou não, o caráter de coisa organizada da obra literária torna-se um fator que nos deixa mais capazes de ordenar a nossa própria mente e sentimentos; e, em conseqüência, mais capazes de organizar a visão que temos do mundo.

Entendemos ter a leitura um enorme poder de transformação do ser; embora desejemos sempre o melhor, é importante atentarmos para a 
consideração do próprio Morin (2005, p.61): "devemos compreender que os seres humanos são seres instáveis, nos quais há a possibilidade do melhor e do pior, uns possuindo melhores possibilidades do que outros."

Portanto, ler não é um processo automático, cujo resultado seja definido e definitivo, pelo contrário, é "um processo de reconstrução desconcertante, labiríntico, comum e, contudo, pessoal." (MANGUEL, 1997, p.54)

Nosso trabalho se faz ancorado no desejo de um futuro melhor, no acreditar na essência humana e na possibilidade de transformação, de transcendência.

Esse acreditar não se esgota porque nós, enquanto educadores, temos clareza de nosso objetivo: ajudar na formação intelectual e emocional do ser dos humanos. Ajudar, visto que a formação é constituída por diversas instâncias: família, escola, religião, política, mídia entre outras instituições. Mesmo sabendo das limitações, não podemos nos isentar de nosso papel, por mais que outras instâncias, por vezes, pareçam exercer maior influência, ou, sejam mais "chamativas". Nossa preocupação está em oferecer aos educandos o mesmo ponto de partida, para que depois cada um trace os caminhos de sua própria vida.

Entender a leitura numa perspectiva da complexidade, como a que vimos assumindo, significa entender que há uma dinâmica social de produção de textos nos entrecruzamentos de diversos e diferentes fios, como se estivéssemos tecendo um tapete; e o processo de leitura - em especial da literatura - se configuraria em uma forma muito peculiar de 
acessar esse tecido ou, quem sabe, acessar um tapete voador. Esse por um lado permitiria, pela perspectiva aérea, visualizar o espectro do mundo contemporâneo desenhado por formas perversas de capitalismo, suas propostas de objetividades construídas, e seus racionalismos. Por outro, ler a experiência histórica e os rastros sonhadores que embalam o percurso da afirmação de nossa potencialidade sensível e subjetiva em conjunção com o mundo objetivo, nossa potencialidade humana de ser.

Como nos contos maravilhosos, um tapete que nos leve a aventuras, lugares distantes de fronteiras de compartilhamento, propiciando-nos, enfim, vivenciar e manter vivo o sonho e sua possibilidade de realização (pela práxis da história). Fica o convite. 


\section{Capítulo II}

"O. livros estão aqui, como uma galáxia pulsanke, e as palavras, dentro deles, são outra poeira cósmica flutuando, à espera do othar que as irá fixar num sentido ou nelas procurará o sentido novo, porque assim como vão variando as explicações do universo, também a sentença que antes parecera imutável para todo o sempre oferece subitamente outra inkerpretação" Øosé હaramago

Neste capítulo procuraremos abordar algumas possibilidades que a leitura oferece para novas relações e interpretações frente a textos diversos, considerando a constituição de um novo leitor: o leitor do terceiro milênio.

\subsection{Alguns aspectos da literatura infantil e juvenil brasileira,}

\section{seus diálogos, seus leitores}

Os europeus trouxeram o código verbal, através de livros e outros materiais escritos de sua sociedade e cultura, ao nosso país, no início da colonização, porém foi somente com a implantação oficial da Imprensa Régia em 1808, na ocasião da chegada da família real ao Brasil que, de certa forma, houve um maior acesso ao código verbal escrito. No entanto, vale lembrar, isso ocorre de forma bastante restrita, visto que, em 13 de maio de 1808, D.João VI decreta que a Imprensa Oficial se destinaria exclusivamente a serviço do governo real.

Em $1^{\circ}$ de junho de 1808, Hipólito José da Costa Pereira Furtado de Mendonça lança o Correio Braziliense ou Armazém Literário, primeira publicação livre de censura, impresso em Londres e enviado mensalmente ao Brasil. O periódico era dividido em quatro segmentos: Política, 
Comércio e Artes, Literatura e Ciências, Ciências e Miscelânea.

CORREIO BRAZLLENSE

DE JUNHO, 1808.

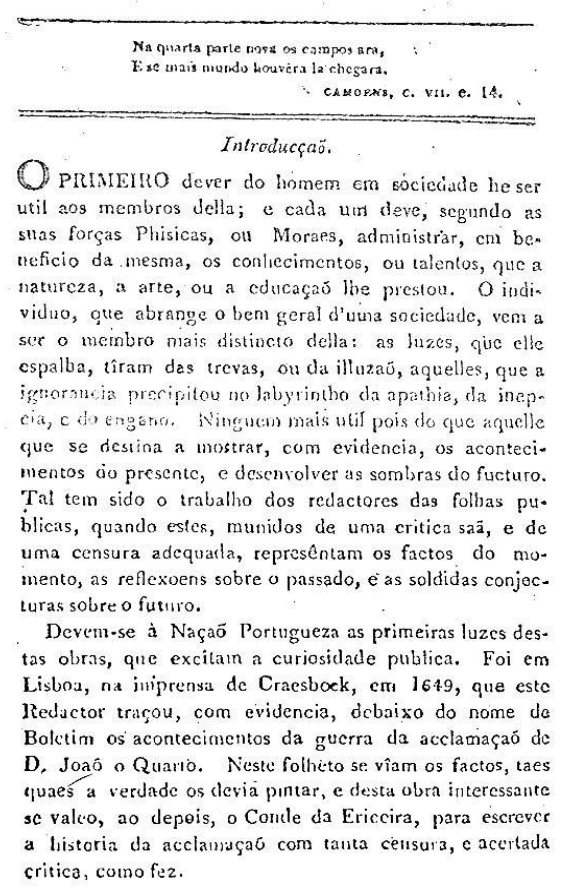

Primeira página da 1 aedição do Correio Braziliense

O jornal tinha uma configuração bem diferente da que possui atualmente, implicando em uma leitura mais linear; a impressão do periódico e sua distribuição mensal também vão implicar em uma percepção mais duradoura do tempo e dos fatos.

Nessa época, escolas foram construídas e houve, conseqüentemente, um aumento na procura de livros, sobretudo, "infantis". A princípio eram traduções e adaptações de obras estrangeiras e mais tarde uma literatura que, pelo contexto histórico-político de repressão e censura, acabava por abordar principalmente valores como o nacionalismo, o intelectualismo, o moralismo.

O leitor dessa época configura-se como leitor contemplativo, 
meditativo7. Na concepção de Santaella, aquele leitor que tem diante de si textos duráveis (livros, jornais) e que podem ser revisitados a todo e qualquer momento. Aquele para quem o tempo não conta. "Um leitor que contempla e medita. Entre os sentidos, a visão reina soberana, complementada pelo sentido interior da imaginação" (SANTAELLA, 2007, p.24).

"O Tico-Tico" foi a primeira revista em quadrinhos publicada no Brasil, em 11 de outubro de 1905, pela editora O Malho (RJ), cujo diretor era o mineiro Luiz Bartolomeu de Sousa Silva. Sua publicação se destaca pelo seu caráter lúdico, pois até então, os livros de literatura infantil prezavam pela exemplaridade e valores morais.

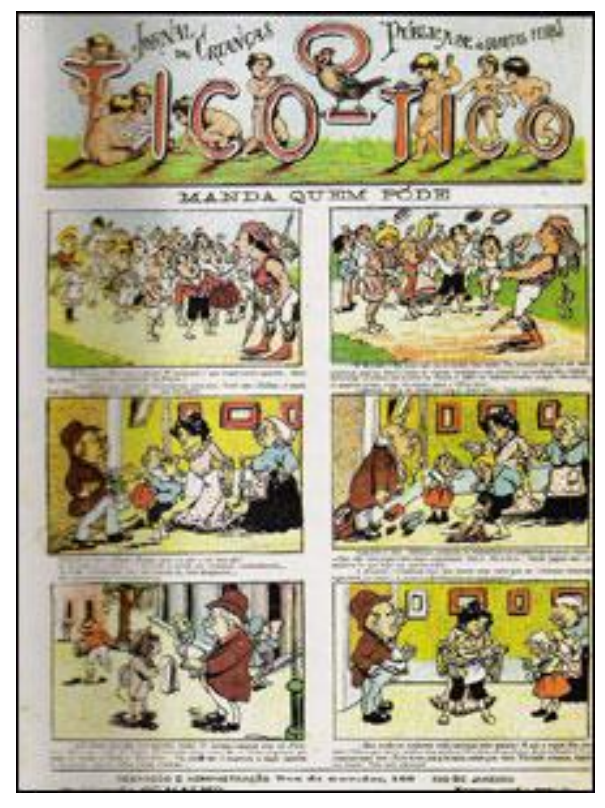

A partir da década de 1920 , houve uma guinada no contexto político e social do Brasil.

\footnotetext{
7 Neste trabalho utilizaremos a concepção de Santaella quanto aos tipos de leitor por ela definidos: contemplativo/meditativo, movente/fragmentado e imersivo/navegador.
} 
O processo de modernização da sociedade brasileira que se deu através do estímulo ao crescimento industrial e à urbanização, beneficiou a cultura brasileira, na medida em que proporcionou condições de produção, circulação e consumo dos bens de que aquela se constituía. A literatura infantil também foi favorecida, já que a indicação de livros se solidificou e a escola, cujo resultado mais imediato é o acesso à leitura, se expandiu. (LAJOLO, 1999, p.119)

Com a expansão dos centros urbanos e maior difusão dos meios de comunicação, o ritmo de vida tornou-se mais célere, exigindo do leitor uma nova postura, um novo olhar.

A Semana da Arte Moderna representa bem esse novo olhar, que rompe com o tradicional e busca outros caminhos.

Na literatura infantil, o marco foi Monteiro Lobato que "rompe pela raiz, com as convenções estereotipadas e abre as portas para as novas idéias e formas que o nosso século exigia" (COELHO, 1987, p.225).

Em 1920, Lobato publica "A menina do narizinho arrebitado", um livro grande e cheio de ilustrações coloridas, empolgado com o sucesso, resolve se arriscar no mercado editorial escolar e manda fazer uma edição com custo menor e sem gravuras coloridas, surge, então em 1921, a edição escolar "Narizinho arrebitado", adotado no governo de Washington Luiz em toda rede escolar. 

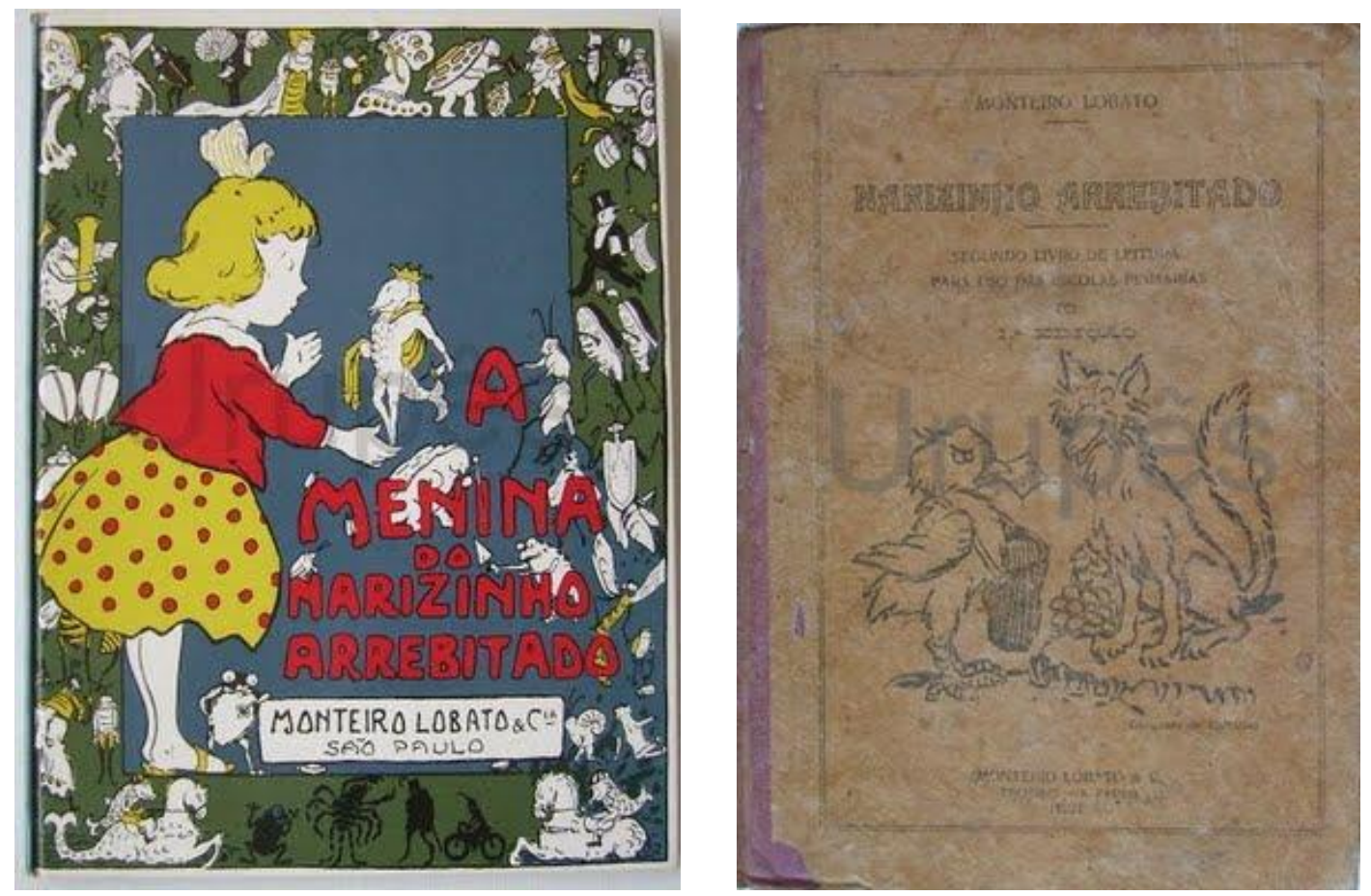

Na década de 1940 difunde-se a literatura-em-quadrinhos (Coelho, 1987) cuja leitura demanda habilidades diferentes, pois nela se encontra o cruzamento de linguagens diversas, portanto, o leitor também é outro.

Em 1947 foram lançadas revistas (que viriam a ter atenção de um público juvenil) como: "Dick Peter" de Jerônimo Monteiro, "Morena Flor" de André Le Blanc, entre outras revistinhas infantis como: Correio Universal, Lobinho, Sesinho, Vida Infantil. 

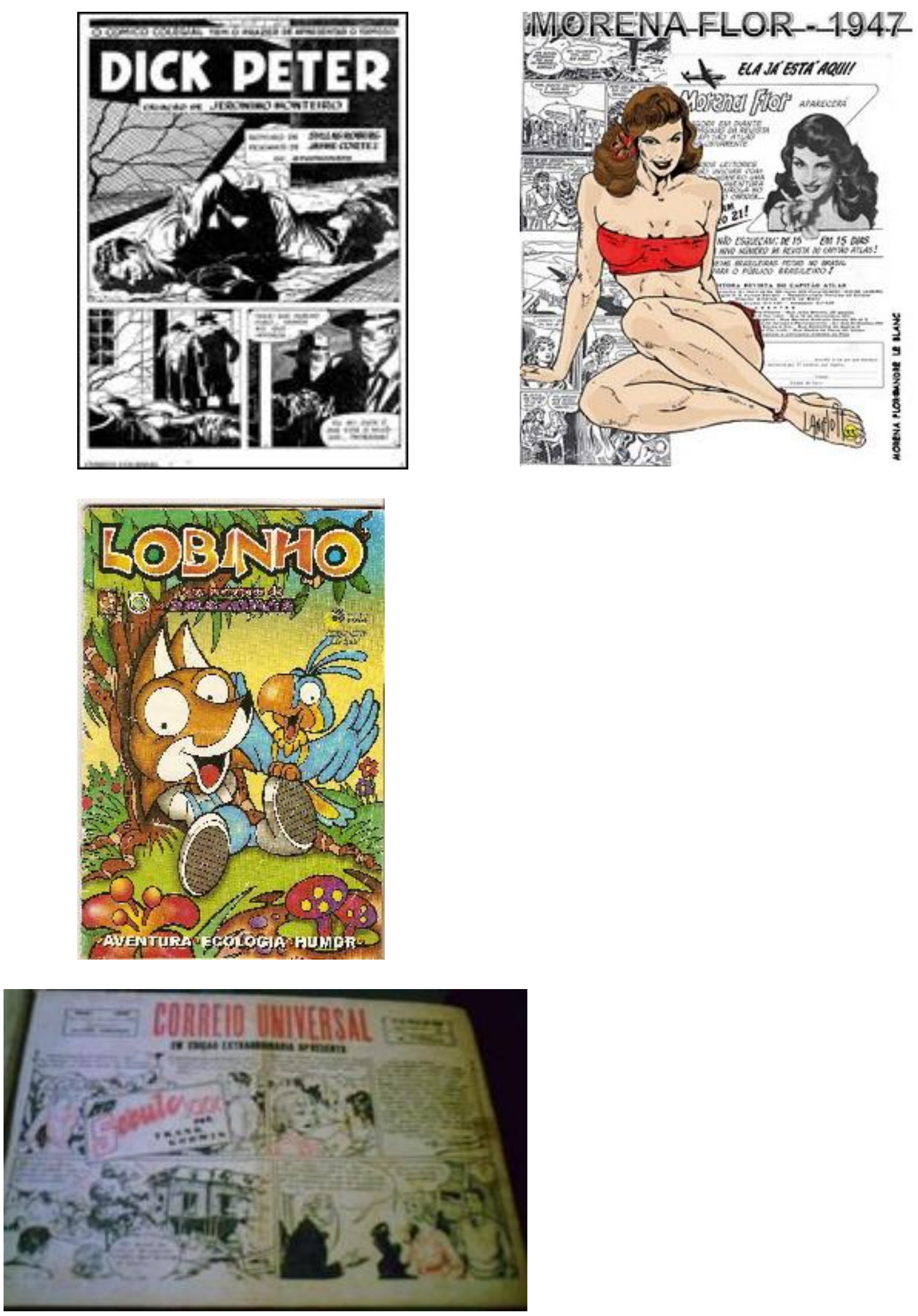

Foi na década de 50 que as Produções Walt Disney entram no 
mercado brasileiro com a revistinha mensal O Pato Donald.

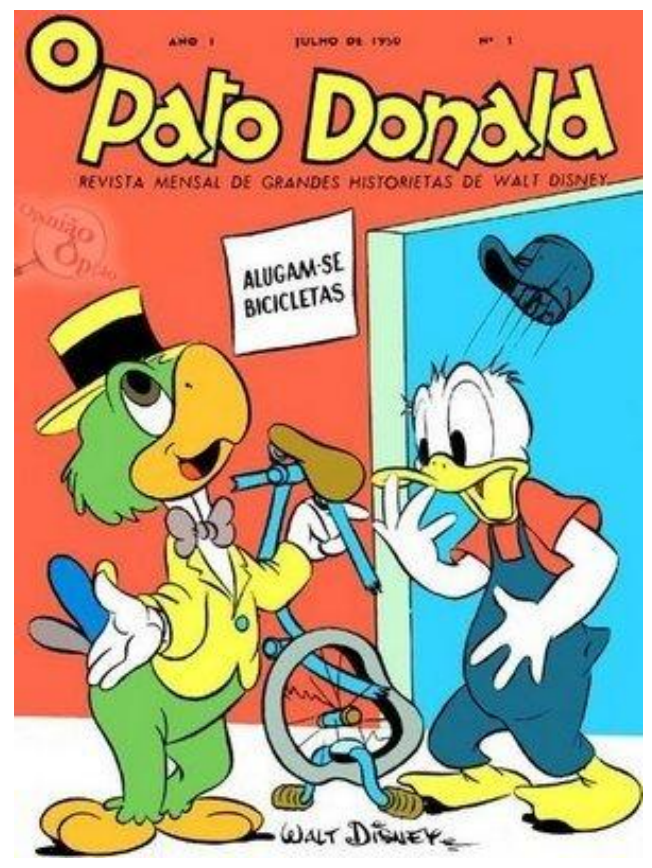

Nas décadas de 60 e 70 surgem Ziraldo e Maurício de Sousa com personagens e temas brasileiros:

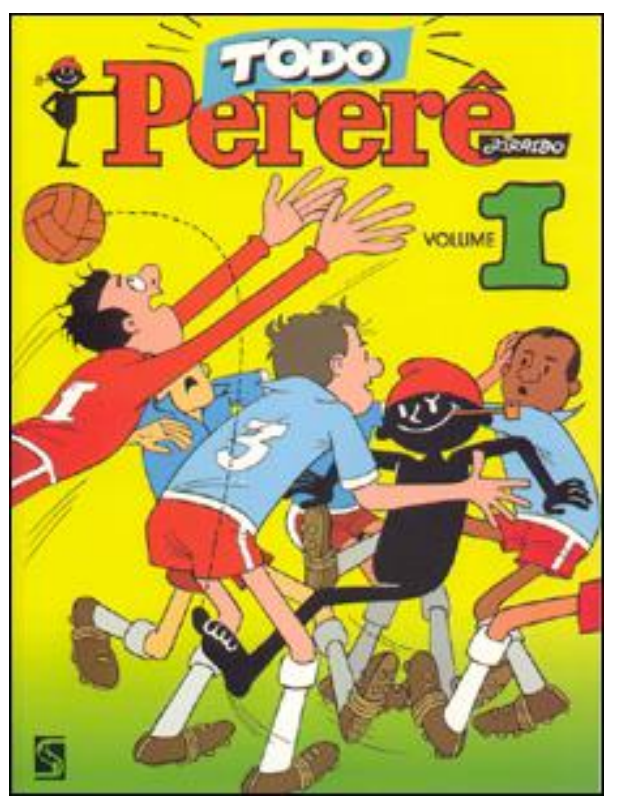




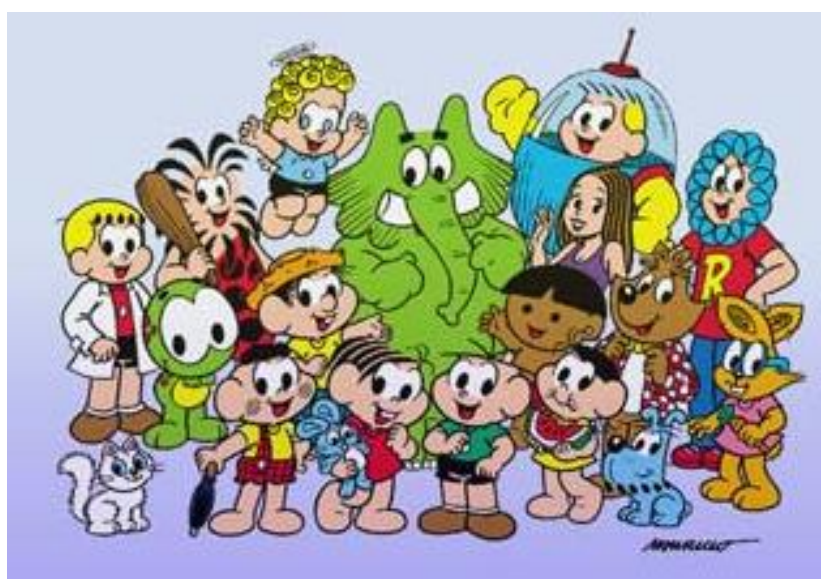

Na década de 80, consolidou-se o trabalho de vários artistas, tais como os cartunistas Angeli, Glauco e Laerte que juntos produziram as aventuras de "Los três amigos"

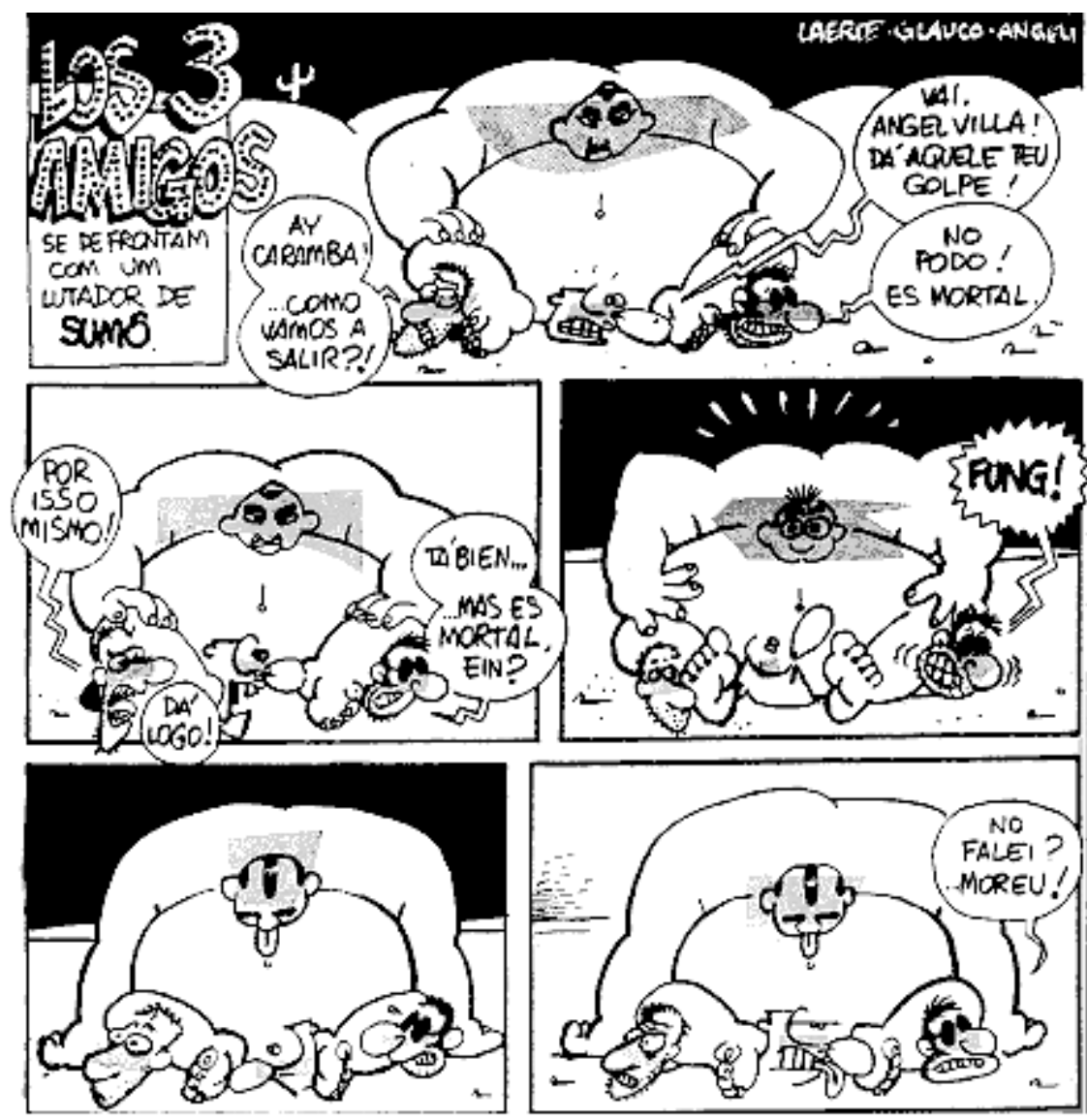

Não podemos esquecer de que o convívio das HQs com as programações televisivas (em especial, o jornal e desenhos animados), propiciou a proliferação de signos novos e mutantes, lembrando que no 
Brasil o primeiro canal de TV foi inaugurado em 1950(TV Tupi).

A produção de livros para crianças e jovens passa então a compartilhar com outras mídias a atenção das crianças e jovens. Nesse contexto, temos a emergência de um segundo tipo de leitor: o movente, fragmentado.

É um leitor que esbarra

a todo instante em signos, signos que vêm ao seu encontro, fora e dentro de casa, esse leitor aprende a transitar entre linguagens, passando dos objetos aos signos, da imagem ao verbo, do som para a imagem com familiaridade imperceptível. (SANTAELLA, 2007, p.31)

Santaella continua

nessa nova realidade, as coisas se fragmentam sob efeito do transitório, do excessivo, da instabilidade que marcam o psiquismo humano com a tensão nervosa, a velocidade, o superficialismo, a efemeridade, a hiperestesia, tudo isso convergindo para a experiência imediata e solitária do homem moderno. (Ibidem, p.29)

A leitura desse mundo moderno passa a ser rápida e fragmentária; os livros de literatura infantil e juvenil, agora, dividem o espaço da página entre imagem e texto verbal; informações novas surgem a cada instante nas ruas por meio de jornais, de revistas, das vitrines, dos out doors e dentro das casas com os mais diversos programas de T.V: desenhos animados, telenovelas, jornais etc; esses aspectos exigem do leitor um olhar mais dinâmico, interativo e lúdico.

Mais recentemente, o processo de digitalização propicia a mais nova 
revolução tecnológica e, com ela, entre outras conseqüências, há o nascimento de uma nova linguagem - a hipermídia - em um ambiente no qual ler, perceber, pensar e sentir adquirem novas características. Entra em cena um terceiro tipo de leitor: o imersivo, o virtual.

\subsection{Em cena o leitor do terceiro milênio - O leitor navegador}

Lévy (1993, p.7) afirma que atualmente

As relações entre os homens, o trabalho, a própria inteligência dependem, na verdade, da metamorfose incessante de dispositivos informacionais de todos os tipos. Escrita, leitura, visão, audição, criação, aprendizagem são capturados por uma informática cada vez mais avançada.

Vivemos a era chamada digital em que as diversas relações (entre linguagens, meios, pessoas), contínua e constantemente, mudam e se combinam de formas diversificadas.

Para Benjamim (1994, p.169), as mudanças da técnica e do modo de produção estão atreladas às transformações da percepção:

No interior de grandes períodos históricos, a forma de percepção das coletividades humanas se transforma ao mesmo tempo que seu modo de existência. O modo pelo qual se organiza a percepção humana, o meio em que ela se dá, não é apenas condicionado naturalmente, mas também historicamente.

Atualmente, termos como hipertexto, multimídia e hipermídia se difundem cada vez mais e para elucidar sua utilização em nosso trabalho, recorremos à conceituação breve e esclarecedora de Leão (2005): 
O hipertexto é um documento digital composto por diferentes blocos de informações interconectadas. Essas informações são amarradas por meio de elos associativos, os links. Os links permitem que o usuário avance em sua leitura na ordem que desejar. (p.15)

Multimidia é a incorporação de informações diversas como som, textos, imagens, vídeo, etc. em uma mesma tecnologia - o computador. (p.16)

Hipermídia, por sua vez, é uma tecnologia que engloba recursos do hipertexto e multimídia, permitindo ao usuário a navegação por diversas partes de um aplicativo, na ordem que desejar. (p.16)

Em um cenário como esse, surge um novo leitor: o imersivo, virtual.

Um leitor que navega numa tela, programando leituras, num universo de signos evanescentes e eternamente disponíveis, contanto que não se perca a rota que leva a eles. (SANTAELLA, 2007, p.33)

Trata-se de uma rota labiríntica, portanto, torna-se imprescindível o estado de prontidão e alerta, pois caso uma conexão não prevista, seja efetuada, sua rota se altera totalmente, levando o navegador a outras redes não pretendidas.

Chartier (1999, p.12) coloca que:

a inscrição do texto na tela cria uma distribuição, uma organização, uma estruturação do texto que não é de modo algum a mesma com a qual se defrontava o leitor do livro em rolo da Antiguidade ou o leitor medieval, moderno e contemporâneo do livro manuscrito ou impresso, onde o texto é organizado a partir de sua estrutura em cadernos, folhas e páginas. O fluxo seqüencial do texto na tela, a continuidade que lhe é dada, o fato de que suas fronteiras não são mais tão radicalmente visíveis, como no livro que encerra, no interior de sua encadernação ou de sua capa, o texto que ele carrega, a possibilidade para o leitor de embaralhar, de entrecruzar, de reunir textos que são inscritos na mesma memória eletrônica: todos esses traços 
indicam que a revolução do livro eletrônico é uma revolução nas estruturas do suporte material do escrito assim como nas maneiras de ler.

Santaella e Chartier afirmam que o leitor do texto eletrônico é mais livre, na medida em que este permite ao leitor múltiplas possibilidades de interferências nos mais diversos níveis do texto.

Como já foi dito, o mundo todo e todo o mundo estão em transformação, logo, a leitura deve ser enfocada com um novo olhar. A escola, enquanto instância formal, pode possibilitar além do acesso, a aprendizagem dessas novas formas de abordagem e apreensão de textos diversos.

Nessa ordem de ideias, é de suma importância entender como o leitor do mundo contemporâneo interage cognitivamente com esse novo objeto, as midia. Quem é esse leitor?

O leitor do terceiro milênio é

um leitor em estado de prontidão, conectando-se entre nós e nexos, num roteiro multilinear, multisseqüencial $e$ labiríntico que ele próprio ajudou a construir ao interagir com os nós entre palavras, imagens, documentação, músicas, vídeo etc.(SANTAELLA, 2004, p.33)

O perfil cognitivo desse leitor foi classificado por Santaella segundo o método peirceano de investigação, baseado nas três categorias cognoscitivas: primeiridade, secundidade e terceiridade, considerando as três formas de inferência lógica ou raciocínio: abdução, indução e dedução. 
O quadro abaixo mostra os três tipos de leitor imersivo ${ }^{8}$.

\begin{tabular}{|c|c|c|}
\hline $\begin{array}{l}\text { Errante/ } \\
\text { Novato }\end{array}$ & $\begin{array}{l}\text { Detetive/ } \\
\text { Leigo }\end{array}$ & $\begin{array}{l}\text { Previdente/ } \\
\text { Experto }\end{array}$ \\
\hline $\begin{array}{l}\square \text { Abdução } \\
\square \quad \text { Adivinhação } \\
\square \text { "é o navegador } \\
\text { que vai clicando } \\
\text { meio sem rumo em } \\
\text { um campo de } \\
\text { possibilidades } \\
\text { abertas. } \\
\text { experiência é típica } \\
\text { de um explorador. } \\
\text { Sem começo, meio e } \\
\text { fim claramente } \\
\text { definidos, } \\
\text { navegação é uma } \\
\text { aventura." }\end{array}$ & $\begin{array}{l}\square \text { Indução } \\
\square \quad \text { Investigação } \\
\square \quad \text { "navegar como um } \\
\text { detetive é aprender com } \\
\text { a experiência, que vai } \\
\text { transformando a } \\
\text { dificuldade em estratégia } \\
\text { e adaptação. [...] é um } \\
\text { experimentador que } \\
\text { discrimina as alternativas } \\
\text { com alerta para os } \\
\text { detalhes e as testa como } \\
\text { um legítimo } \\
\text { investigador." }\end{array}$ & $\begin{array}{l}\square \text { Dedução } \\
\square \quad \text { Antecipação } \\
\square \quad \text { "por ter internalizado } \\
\text { as regras do jogo da } \\
\text { navegação sua mente } \\
\text { está sob o domínio de } \\
\text { hábitos ou associações } \\
\text { que fazem com que } \\
\text { essas regras gerais } \\
\text { suscitem quecões } \\
\text { correspondentes, quer } \\
\text { dizer, a execução de } \\
\text { procedimentos } \\
\text { navegacionais } \\
\text { condizentes com as } \\
\text { regras." }\end{array}$ \\
\hline
\end{tabular}

O leitor do texto midiático, assim como o leitor do texto verbal, conduz a leitura conforme suas habilidades, estratégias e conhecimento prévio utilizados.

Diante de um objeto novo, o hipertexto, o leitor, assim como ocorre no processo de leitura do código verbal, precisa conhecer a técnica para acessá-lo, no caso, o mouse, o teclado, o computador em si e os modos de decifrar seus códigos. Daí inicia-se a exploração que é motivada por predições acionadas pelos ícones, movimentos, sons, ao longo da navegação; o leitor imersivo tenta compreender o funcionamento por meio de cliques ou seta do mouse, quando finalmente internaliza as

8 SANTAELLA, Lucia. Navegar no ciberespaço: o perfil cognitivo do leitor imersivo. São Paulo: Paulus, 2004. 
regras, passa a explorar a multivariada possibilidade do hipertexto, dos limites impostos pelo programa, orientado pelo objetivo da sua feitura, seja esse para fruição artística ou satisfação de outro objetivo (informação acadêmica, jornalística etc).

Portanto, para que o leitor ultrapasse o nível de errante para detetive ou previdente é necessário que a leitura dos novos códigos seja efetiva, pois "a chave para compreender o universo está em nossa capacidade de lê-los adequadamente e dominar suas combinações." (MANGUEL, 1997, p.21)

A questão que se coloca hoje não é apenas o acesso, mas sobretudo da "qualidade da resposta", Plaza (2003, p.24) afirma:

O principal problema da leitura, agora transferido para as questões da interatividade, é o da qualidade da resposta, qualidade da significação, ou seja, qualidade do interpretante. É aqui que reside o nó da questão, pois todo leitor escolhe e é escolhido. Neste sentido, o leitor interativo deve escolher as melhores opções que lhe convém para se manifestar como leitor criativo ou não.

Não basta o leitor internalizar as regras e ser "experto ou previdente", ele deve também estar aberto à experiência sensível, fruir perceptiva e cognitivamente. Santaella (2007, p.180) afirma que:

A figura ideal do leitor imersivo deveria ser aquela capaz de misturar de modo equilibrado os três níveis de leitura imersiva: o errante, o detetivesco e o previdente. O ideal é que esse leitor não se entregue às rotinas sem imaginação do previdente, mas se abra para as surpresas, entregue-se às errâncias para poder voltar a vestir a roupagem do detetive, farejando pistas. 
O leitor, seja ele, contemplativo, movente ou imersivo deve, além de desfrutar do prazer espontâneo da leitura, conhecer e reconhecer as estratégias utilizadas pelo autor, para assim, como Goethe já dizia, julgar gozando ou gozar julgando para propriamente recriar a obra de arte.

\subsection{Lendo a leitura na escola}

Para instrumentalizarmos adequadamente nossos jovens, há de se começar pelos educadores, para que estes entendam e saibam lidar com esse novo paradigma. Um paradigma multifacetado, pois podemos comparar esse "novo mundo" a um caleidoscópio. Feito de várias peças que conforme giram formam uma nova imagem, nunca a mesma. Assim é nas relações que se estabelecem entre códigos, linguagens, imagens, enfim, o conhecimento dar-se-á pelo entendimento desses entrecruzamentos, das possibilidades infinitas de outras relações. Nesse âmbito, nasce um novo olhar, pois novas formas e estruturas de pensamento estão sendo criadas, além de outros modos de ver-apalpar o mundo e interagir com ele. ${ }^{9}$

O mundo está a nossa volta para ser lido, entendido e transformado. É o leitor quem engendra esse processo. Mas não um leitor qualquer, e sim o profícuo, aquele que compartilha com o texto uma linguagem comum ${ }^{10}$, aquele que tem em seu bojo intelectual e sensível, mecanismos de decifração, entendimento e, por conseguinte, de 
transformação.

A formação desse leitor, depende em grande parte do professor, aquele que faz mediações de leitura, um intelectual que oportuniza efetivamente o processo de ler contribuindo para a formação de um ser que participe, apresente questões diante das transformações que vêm ocorrendo na sociedade e no mundo.

Consideramos intelectual aquele que

não é nem um pacificador nem um criador de consensos, mas alguém que empenha todo o seu ser no senso crítico, na recusa em aceitar fórmulas fáceis ou clichês prontos, ou confirmações afáveis, sempre tão conciliadoras sobre o que os poderosos ou convencionais têm a dizer e sobre o que fazem. (SAID, 2005, p.36)

A criticidade é ponto-chave para que o educador possa

\begin{abstract}
ajudar as mentes adolescentes a se movimentar na noosfera (mundo vivo, virtual e imaterial, constituído de informações, representações, conceitos, idéias, mitos que gozam de uma relativa autonomia e, ao mesmo tempo, são dependentes de nossas mentes e de nossa cultura) e ajudá-las a instaurar o convívio com suas idéias, nunca esquecendo que estas devem ser mantidas em seu papel mediador, impedindo que sejam identificadas com o real. (MORIN, 2002a, p.53)
\end{abstract}

Um dos meios mais eficazes e prazerosos para essas idas e vindas da noosfera é a Literatura, em particular, a Literatura Infantil, que não é dedicada apenas às crianças, mas também aos jovens e adultos. Sua riqueza de significações, problemáticas e encantamento supera faixas etárias e o professor conhecedor das várias significações das obras, suas múltiplas possibilidades, também poderá oferecer ao leitor-educando diversas portas e janelas para serem abertas e descobertas e retornar ao 
ponto inicial, se for o caso, recomeçando a explorar, abrir e descobrir outras novas relações, novas possibilidades, novos olhares. Afinal,

participamos de uma revolução da visão, se é verdade que ela não é apenas a materialização de um dos órgãos sensoriais, mas, antes de mais nada, uma construção histórica e cultural. Se quisermos, dessa maneira, participar dessa construção, devemos mergulhar nesse novo sistema da visualidade informática, trabalhando-o não apenas com base em nossas idéias, mas deixando-o, também, trabalhar sobre nossas idéias. ${ }^{11}$

Educar o olhar para as diferentes leituras possíveis (palavras, imagens, cores, texturas, etc) é estarmos dispostos a aprender um novo ponto-de-vista para podermos oferecer ao educando algumas chaves, iniciando sua incursão num mundo sígnico, que tal como a Esfinge de Tebas, a cada momento, lança novos enigmas "Decifra-me ou devoro-te". Ao decifrar, o viajante-leitor continua sua caminhada, decide seus próprios rumos, aprende novos mecanismos de ação; ao ser devorado, o viajanteleitor apenas reage de forma condicionada frente aos estímulos exteriores, seu horizonte se apequena. Mas sempre há outra chance de ascese, de libertação, vindas da aprendizagem de mecanismos multifacetados para a compreensão desse mundo que não cessa de se transformar. Portanto,

quanto melhor estiver capacitado a ler este mesmo universo, melhor será sua própria relação de significação com este complexo de mensagens, e mais profunda sua possibilidade de intervir no conjunto das mensagens, transformando suas

11 Samain, Etienne. "Questões heurísticas em torno do uso das imagens nas ciências sociais" in: FELDMAN-BIANCO, B. e LEITE, M.L.M.(orgs) Desafios da imagem: Fotografia, iconografia e vídeo nas ciências sociais.Campinas, SP:Papirus, 1998,p.61. 
relações estruturais. ${ }^{12}$

Nelly Novaes Coelho (1987) afirma que a escola é um espaço privilegiado para oferecer as descobertas da leitura, embora realmente seja, é impossível falar sobre o processo de leitura, a formação do Ser, sem tocar em questões delicadas: o político e o social. Como diz Said $(2005$, p.26):

O intelectual age com base em princípios universais: que todos os seres humanos têm direito de contar com padrões de comportamento decentes quanto à liberdade e à justiça da parte dos poderes ou nações do mundo, e que as violações deliberadas ou inadvertidas desses padrões têm de ser corajosamente denunciadas e combatidas.

Portanto, não podemos deixar de considerar a realidade da educação na escola pública.

Temos acesso a muitas publicações, entrevistas, palestras, nas quais o problema da "crise" escolar e, conseqüentemente, da leitura recai unicamente sobre os professores. Eles, ou melhor, nós ${ }^{13}$ somos apenas uma parte dessa engrenagem, indispensáveis, pois somos nós que movimentamos essa grande "máquina" por estarmos face-a-face com os educandos e interagirmos diretamente com eles.

O dia-a-dia de uma escola pública é bem peculiar. Somente para exemplificarmos, o número de alunos por sala é de 35 a 45 (em algumas, até 50 !), os recursos materiais para os professores são escassos e quanto à formação dos mesmos, a busca é quase sempre solitária; não há 12 GARDIN, Carlos e OLIVEIRA, Maria Rosa Duarte. "Semiótica e Educação". In: Cadernos PUC - Arte \&Linguagem. № 14,p. 49.

13 Nós, porque todos que trabalham com Literatura são educadores, direta ou indiretamente. 
incentivo, e muitas vezes mesmo o professor querendo, não consegue por motivos diversos: financeiros, de horário (a maioria precisa ter dupla jornada de trabalho) ou até mesmo, infelizmente, por descrença na educação.

Na escola pública há, também, uma diversidade de situações, por vezes, tristes demais: muitas crianças em situação de risco, pais que bebem, que estão ou foram presos, moradia e alimentação precárias, etc. O ser destes pequenos parece esvair-se pela constante violência que sofrem, pela não perspectiva de melhoria, pela degradação da autoestima.

Diante dessa situação, investir em programas de leitura é uma necessidade, urge resgatar a humanidade dentro dessas crianças, desses jovens (quiçá, dentro de nós), tornando-os mais sensíveis, mais solidários, respeitosos e mais respeitados. É possível que assim estejamos contribuindo para a constituição de um mundo mais justo, mais ético, mais feliz.

Frente ao espectro dessa dura realidade, alguns professores perderam o Eros pela profissão, estão desacreditados; mas há muitos outros que conseguem várias vitórias, acreditam no seu trabalho e no potencial dos educandos. Manter essa chama acesa nestes e reacender naqueles é de fundamental importância.

Morin (2002a, p.102) assevera que o ensino sem Eros é mera carreira, educar exige muito mais, "o Eros permite dominar a fruição ligada ao poder, em benefício da fruição ligada à doação. É isso que, antes 
de tudo mais, pode despertar o desejo, o prazer e o amor no aluno e no estudante."

Só se desperta o amor no outro, se estiver disposto a oferecer amor ao outro.

Embora haja controvérsias com relação à denominação do professor como profissional especialista ou como alguém que tem uma missão, acreditamos que a segunda agregada à primeira nos traduz um passo a frente do profissional, se considerarmos que para atuar na missão de educar, temos que ser profissionais competentes, dominar os novos instrumentos de apoio que o mundo contemporâneo exige, mas também devemos acreditar no potencial do ser humano.

Citando novamente Morin (2002a, p.102):

A missão supõe, evidentemente, fé: fé na cultura e fé nas possibilidades do espírito humano. Portanto, é missão muito elevada e difícil, uma vez que supõe, ao mesmo tempo, arte, fé e amor.

Toda leitura é um ato de amor, pois implica em receber um pouco do outro através dos textos (verbais ou não) que só se completam com a generosidade do leitor. O sentido da leitura é reconhecer o outro, sua criação, seu potencial. Ler é um ato solidário (por vezes, solitário) de descoberta de si e do próximo.

Talvez cause estranheza falar em amor, solidariedade nos tempos atuais de máquinas e dígitos, no entanto, a nosso ver, mais do que nunca necessário. 


\section{Capítulo III}

$$
\begin{aligned}
& \text { "A posia coloca o homem fora de si e simultaneamente o faz regressar as sen ser } \\
& \text { original: volla-o para si. } \mathcal{O} \text { homem é sua imagem: ele mesmo e aquele outro. Ahravés } \\
& \text { da frase que é ritmo, que é imagem, o homem - esse perpétur chegar a ser - é. } \\
& \text { A possia é entrar no ser." } \\
& \text { Octavio } \mathscr{P}_{\text {az }}(1922, p .50)
\end{aligned}
$$

Neste capítulo, faremos algumas considerações sobre poesia e tangenciaremos alguns aspectos da teoria peirceana. A seguir apresentaremos a leitura de três obras de literatura infantil e juvenil: $O$ cântico dos cânticos de Ângela Lago, Mandaliques de Tatiana Belinky e Chá de Sérgio Capparelli.

\subsection{Poesia: breves reflexões}

Neste trabalho, consideramos poesia como ritmo que

engendra em nós uma disposição de ânimo que só poderá se acalmar quando sobrevier "algo". Coloca-nos em atitude de espera. Sentimos que o ritmo é um "ir em direção a" alguma coisa, ainda que não saibamos o que seja essa coisa. Todo ritmo é sentido de algo. Assim, o ritmo não é exclusivamente uma medida vazia de conteúdo, mas uma direção, um sentido. (PAZ, 1982, p.68)

O homem necessita de sentido para viver o mundo, pois como diz Octavio Paz (1982, p.23), o homem "tolera a ambigüidade, a contradição, a loucura ou a confusão, não a carência de sentido".

Salientamos que poesia não se confunde com poema. Este, uma estrutura em versos, aquela, ultrapassa os limites do verbal. Segundo o mesmo autor, (1982), inclusive, há poemas em que não há poesia.

Poesia é algo que está além, algo mágico, por isso, de difícil definição. Não há um lugar exato para ela e, no entanto, de súbito, 
revela-se em todos os lugares.

A poesia coloca o homem fora de si e simultaneamente o faz regressar ao seu ser original: volta-o para si. O homem é sua imagem: ele mesmo e aquele outro. Através da frase que é ritmo, que é imagem, o homem - esse perpétuo chegar a ser - é. A poesia é entrar no ser. (PAZ, 1982, p.178)

Talvez a poesia seja o próprio ser. Afinal, aquele que não for tocado por ela, não a verá em lugar algum; já o ser tangido por ela,

De repente se recorda de sua identidade perdida, e então, aparece, emerge esse "outro" que somos. Poesia e religião são revelação. [...] é a revelação de si mesmo que o homem faz a si mesmo. (PAZ, 1982, p.166)

Dessa forma, o olhar desse ser muda, e conseqüentemente, há a geração de um novo sentido de vida. Um sentido que religa os fragmentos para se ver o todo, em que o EU e o Nós tornam-se indissociáveis, mas não se confundem.

Nelly Novaes Coelho ${ }^{14}$ coloca que:

Em face da turbulência desnorteada e destruidora que domina o nosso cotidiano massificado cada vez mais, o indivíduo é levado a se identificar com as idéias e formasde-vida da 'aldeia global', e a se tornar cada vez mais estranho a si mesmo, a alienar-se de seu próprio Eu ou de sua possível verdade.

Uma das formas de desalienação é, justamente, através da Poesia. Afinal,

a poesia é metamorfose, mudança, operação alquímica, e

${ }^{14}$ COELHO, N.N. A poesia como ato de busca. O Estado de São Paulo. Cultura, São Paulo, 7(353): 8-9, 21 mar.1987,p.9 
por isso confina com a magia, a religião e outras tentativas para transformar o homem e fazer 'deste' ou 'daquele' esse 'outro' que é ele mesmo. (PAZ, 1982, p.137)

Nas palavras de Morin (2005, p.43), a poesia refere-se a questões subjetivas, simbólicas, míticas, mágicas. Para esse autor,

O objetivo que permanece fundamental na poesia é o de nos colocar num estado segundo, ou, mais precisamente, fazer com que esse estado segundo converta-se num estado primeiro. O fim da poesia é o de nos colocar em estado poético.

Estar em estado poético possibilita-nos perceber o universo sendo tecido por fios diversos, em uma tessitura complexa, não uma construção mecânica. Esse é um tecer entremeado de poesia, de magia, de boniteza. Para que a compreensão do universo seja dessa forma, a leitura efetiva, sendo um ato social e subjetivo, possibilita oferecer dois movimentos: 1)da fruição, afetividade à cognição, atividade intelectual ou 2)da compreensão cognitiva/intelectual à fruição afetiva.

Coelho (2000, p.127) afirma que:

o poder mágico da mente será o elemento-chave para a exploração dinâmica (e não mecânica) do poder da tecnologia, que comandará as relações eu-mundo nesse terceiro milênio.

Portanto, mais do que nunca, é necessário resgatar o lado simbólico, emotivo, sensorial, que há muito tempo vem sendo escondido e tratado como algo de menor valor.

Quando a poesia toca a sensibilidade do homem, ocorre a comunhão 
dele com o universo, criador e criatura. O homem percebe-se como criatura desse imenso universo, mas também como criador, agente transformador desse que o criou.

A poesia resgata o humano quando desperta a "sensação de encantamento", adormecida na fadiga do olhar apático daquele que vê, mas não enxerga; daquele que vive, mas não vivencia a vida, não transforma, não intervém, não se faz presente no mundo.

A poesia é "reconciliação: ontem, hoje, amanhã; aqui e ali; tu, eu, ele, nós. Tudo está presente: será presença". (PAZ, 1982, p.348)

\subsection{Signos em mutação}

Leitura é semiose, é a ação do signo. Em constante mutação, um signo dá vida a outro mais complexo e mais desenvolvido. Isto constitui um dos princípios da lógica peirceana, que possibilita compreendermos como toda atividade mental tem início na percepção, exige vôos imaginativos e requer formas complexas de raciocínio. Assim se processam as atividades leitoras - processo de compreensão multifacetado que implica: percepcão, memória, processamento de informações, predição, inferência, indução, evocação, analogia, análise, síntese, dedução, avaliação e interpretação. Enfim, um conjunto de estratégias que interagem com diferentes níveis de conhecimento.

A teoria de Peirce é, particularmente, instigante, pois pretende dar conta de todas as Ciências (matemáticas, biológicas, física, lingüística, entre outras). Porém, não é uma teoria que sabe e explica tudo, Peirce foi 
extremamente cauteloso e lúcido ao evidenciar o "caráter inevitavelmente incompleto de qualquer signo, assim como da falibilidade inerente a qualquer interpretação particular" (OESP-08/10/83-Caderno de programas e leituras)

Sendo assim, a teoria peirceana, apresentada a nós, principalmente pelos estudos de Santaella (1993) e Cunha (2009), fornece-nos um arcabouço teórico e possibilita encontrarmos aportes para reflexões acerca de processos perceptivos, cognitivos envolvidos na leitura de objetos artísticos, entre esses, a literatura, a poesia.

As relações triádicas são a essência da teoria lógica-social de Peirce, ele apresenta as três categorias fenomenológicas universais: primeiridade, secundidade, terceiridade.

Primeiridade é o começo, aquilo que tem frescor, é original, espontâneo, livre. Secundidade é aquilo que é determinado, terminado, final, correlativo, objeto, necessitado, reativo. Terceiridade é o meio, devir, desenvolvimento. (SANTAELLA, 1993, p.36)

A noção da tríade objeto-signo-interpretante e as relações que envolvem essa tríade foram esquematizadas por Santaella (1993, p. 39, grifo nosso) de forma bastante didática e esclarecedora:

1) o signo é determinado pelo objeto, isto é, o objeto causa o signo, mas 2) o signo representa o objeto, por isso mesmo é signo; 3) o signo só pode representar o objeto parcialmente e 4) pode até mesmo representá-lo falsamente; 5) representar o objeto significa que o signo está apto a afetar uma mente, isto é, produzir nela algum tipo de efeito; 6) esse efeito produzido é chamado de interpretante do signo; 7) o interpretante é imediatamente 
determinado pelo signo e mediatamente determinado pelo objeto, isto é, 8) o objeto também causa o interpretante, mas através da mediação do signo.

O objeto em si é inapreensível, visto que o signo pode apreender parcialmente (ou até falsamente) alguns aspectos do objeto, não o seu todo. Interpretante não pode ser confundido com intérprete, o primeiro é o efeito que o signo causa ou poderia causar numa mente interpretadora (intérprete).

O signo divide-se ainda em ícone (primeiridade), índice (secundidade) e símbolo (terceiridade).

É importante citar a noção de semiose, que é a ação própria do signo, ou seja, a de gerar/produzir e se desenvolver num outro signo, uma rede infinita de crescimento.

Para Peirce, todo conhecimento entra pela percepção. Santaella (1993, p.51) afirma que a "percepção tem uma natureza híbrida entre a fenomenologia e a semiótica. Pode-se dizer que ela ocupa o ponto exato em que esses dois reinos se cruzam".

Vimos logo acima a noção de signo, agora enfocaremos o processo da percepção. Vale lembrar que nosso processo perceptivo já é mediado semioticamente. Sempre entre nós e os fenômenos se interpõe uma camada de signos.

A percepção envolve três elementos: percepto, percipuum e julgamento perceptivo.

O percepto é aquilo que aparece e se força sobre nós, 
brutalmente, no sentido de que não é guiado pela razão. Não tem generalidade. É físico, no sentido de que é nãopsíquico, não-cognitivo, quer dizer, ele aparece sob uma vestimenta física. É um acontecimento singular que se realiza aqui e agora, portanto irrepetível. (SANTAELLA, 1993, p.91)

Percipuum é "'o percepto tal como ele é imediatamente interpretado no juízo perceptivo'[...] aquele que faz a ponte, mediação, entre nossa mente e o mundo exterior". (SANTAELLA, 1993, p.97)

Julgamento perceptivo é "fruto de elaborações mentais, cognitivas, o que não quer necessariamente dizer que, porque o julgamento é cognitivo, nós temos pleno controle sobre seu processo". (SANTAELLA, 1993, p.106)

Santaella (1993, p.99) afirma que:

há muito pouco ou quase nada de nosso domínio e controle no processo perceptivo. Provavelmente exercemos sobre a formação do julgamento perceptivo o mesmo controle que podemos exercer sobre o crescimento de nossas unhas e cabelos, que, de resto, crescem à nossa revelia, mesmo depois da morte.

Pouco ou quase não exercemos controle sobre o processo perceptivo, porém, acreditamos que quanto melhor estivermos instrumentalizados para perceber os vários elementos e processos que constituem os signos, mais significativa será nossa percepção. Segundo Maria Zilda da Cunha em seu livro, Na tessitura dos signos contemporâneos, a percepção para Peirce é o ponto de partida e o campo de testagem para novas especulações, as mais imaginativas, e a percepção "está na porta de entrada da investigação e do conhecimento, 
por ser insistente, incontestável, incontrolável e, eminentemente falível". (2009, p.30).

Os elementos de todo conceito entram para o pensamento lógico pelo portão da percepção e saem pelo portão da ação intencional; e quem não puder mostrar seu passaporte, em ambas as portas, deve ser preso não autorizado pela razão. (CP 5.211) ${ }^{15}$

Sendo assim, a percepção é a base para o controle racional da ação. Esta é a porta de saída do pensamento. Para Cunha (2009), na perspectiva peirceana, não há separação entre percepção e conhecimento.

A percepção engendra-se na imaginação, posto que o julgamento perceptivo já é da natureza de uma inferência lógica e cognitiva - a abdução - que permite ao homem seus vôos imaginativos - face da percepção que se vincula à forma de raciocínio abdutivo (capacidade de advinhação).

De acordo com Peirce, a abdução é um instinto racional. É o resultado das conjecturas produzidas por nossa razão criativa. Ela é instintiva e racional ao mesmo tempo. Com a palavra "instinto", Peirce quis significar a capacidade de adivinhar corretamente as leis da natureza. (SANTAELLA, 2004, p.95)

Assim, o processo de adivinhação é parte do processo leitor na medida em que a leitura também é lógica e instintiva, ou seja, o instinto racional enovelado no adquirido pela experiência será norteador para a

15 Para citar os principais escritos de Peirce, usaremos $\mathrm{CP}$, abreviatura tradicionalmente reconhecida para indicar os Collected Papers, datados pela sua publicação (póstuma) em 1971. Os números referem-se ao volume e ao parágrafo. No caso acima, lemos "volume 5 parágrafo 211". 
antecipação de sentidos e compreensão dos diversos textos que estão ao nosso redor.

Enquanto a abdução é responsável pela formulação das hipóteses, as demais formas de raciocínio (a dedução e a indução) operam para se obter o controle da leitura, para se chegar a processos de significação, compreensão e a formas de reflexão crítica e também re-criativa dos textos.

Todo processo criador ilustra um caminhar em direção a um autocontrole, posto requerer o poder de contemplação (observação do ícone) no mais alto grau - a luta pela não intrusão de pensamentos estranhos à criação. É própria do artista a tentativa de manter a "sensibilidade" perceptiva. Em suas obras, eles procuram deixar esse rastro sensível, por meio da elaboração estética. Daí, entendermos a poesia como um objeto privilegiado para a regeneração de nossa percepção.

Obviamente que as breves linhas acima não dão conta da profundidade e complexidade da extensa obra de Peirce, porém são noções que se fizeram necessárias. Elas nos propiciam uma compreensão acerca de possibilidades de transcendência do ser através de semioses proporcionadas pelas leituras poéticas, via fruição/ cognição, desafios e intelecção do texto.

Entender tais processos permite-nos desenvolver um olhar mais crítico e atento sobre o processo de captura e incorporação de conhecimentos para a construção e constituição de um ser humano mais sensível, atuante, solidário, ético e reflexivo neste terceiro milênio. 


\title{
3.3 Poesia e êxtase na imagem
}

$$
\begin{array}{r}
\text { "Ta verdade, queria fajer um liver interminável, funcionando como a banda } \\
\text { de Moebius. A pretensão era talieg grande demais e demorei seis anos desenhando, } \\
\text { redesenhando, abandonando e vetomando o trabalho." } \\
\text { Ângela Lago }
\end{array}
$$

\subsubsection{A gênese de "O Cântico dos Cânticos" de Ângela Lago}

"O Cântico dos Cânticos", segundo a própria autora, foi construído sob o signo da paixão, originada pela leitura na Bíblia, aos quatorze anos, dos cantares atribuídos a Salomão. Os mesmos constituem um texto verbal extremamente sensual, erótico, amoroso, há uma profusão de imagens criadas pelas palavras

\author{
Que me beije dos beijos de sua boca, \\ Pois são belos teus seios, \\ São melhores do que o vinho.<smiles>[AlH][AlH]</smiles> \\ Teus lábios fita rubra, \\ E tua fala primavera, \\ Oculta a tua maçã \\ Tem a romã fendida.
}

Diante de tais imagens, a leitura, da autora adolescente, deve ter causado um êxtase incomensurável que deixou marcas em sua alma de menina-moça. Essas marcas foram tão profundas que depois de quase trinta anos, Ângela desejou recuperar esta primeira leitura juvenil. 
Durante longos seis anos, me ocupei, de alguma forma, com este projeto. [...] Todo livro terminou por se resumir, quem sabe, em um único verso. Uma curta oração, feita em um quarto escuro, com a matéria de um sonho. E talvez por isto, eu tenha que pedir ao leitor até mais do que duas leituras: uma contemplação. Tenho que Ihe pedir, não mais que ele reinvente ou construa histórias, mas que se permita o devaneio poético. ${ }^{16}$

O êxtase causado pela leitura reflete-se nas imagens do livro, uma transmutação de formas, perspectivas, cores que nos chegam a causar certa vertigem diante desse objeto extático. (não estático)

A própria autora pede que o livro seja contemplado.

Santaella (1992, p.181) coloca:

a contemplação estética não é contemplação beatificada ou abobada. Ao contrário, é contemplação ativa. Há um fisgamento, algo que nos atrai. Há um entretenimento, algo que nos cativa. Mas há também uma razão que borbulha junto com o sentimento. A suspensão do policiamento da racionalidade, a pura inocência dos sentidos é fundamental ao estado mental estético, mas isso não significa que a razão criativa não entre também em operação para compreender o sentimento.

Ângela pede uma atenção maior, mais demorada, um olhar apurado.

A obra, dada suas características peculiares, é híbrida, portanto, exige um leitor híbrido, em que os três tipos ${ }^{17}$, denominados por Santaella, se mesclem e sejam acionados simultaneamente.

Diante de imagens extáticas, o leitor necessita de tempo para contemplar e dialogar com a obra - leitor contemplativo; os índices

16 LAGO, Angela. O Cântico dos Cânticos: uma leitura através das imagens. PUC-PREPES. Belo Horizonte, 16 de julho de 1992.

${ }^{17}$ Leitor contemplativo, movente e imersivo. 
poéticos que espraiam por toda a obra requer intelecção e conhecimentos (de épocas, estilos, culturas) exigindo um leitor que se movimente nessas diferentes esferas de conhecimento - leitor movente; a obra é construída hipertextualmente, com variados caminhos e links, aciona-se o leitor imersivo.

Quanto mais nos demoramos contemplando a obra, tentando decifrá-la, mais nosso olhar se intriga e se encanta, mais caminhos são explorados, fazendo com que ela sempre mantenha certo frescor e solicite nova leitura, pois como diz Ferrara (1986, p.22), "o homogêneo não é passível de leitura", o igual não provoca nossa percepção, não nos move. Então, para que possamos sempre ter a "sensação de encantamento" diante de um signo estético, é necessário que o próprio signo proporcione estranhezas a cada novo olhar, "assim como não é possível ler o homogêneo, não é possível ler/ ver/ perceber o que não conseguimos estranhar" (FERRARA, 1986, p.32)

A empreitada de Ângela Lago foi grandiosa, mas enfim, ela conseguiu: um livro interminável. Um livro que não tem fim nos dois aspectos: físico e interpretativo. Uma obra de arte.

\subsubsection{A obra - vários olhares}

O livro "O Cântico dos Cânticos" de Ângela Lago é uma transmutação, ou tradução intersemiótica nas palavras de Julio Plaza, de "Cântico dos Cânticos" de Salomão. 
Segundo Plaza (2003, p.162) "ler para a tradução é detonar na mente o Insight, centro imantado da transmutação sígnica, que por sua vez será traduzido e materializado" e ainda, (p.165) "transmutação é uma atividade lúcida e lúdica", assim compreendeu Ângela ao conceber o livro. Como já foi dito, a autora quis resgatar a primeira impressão da leitura dos cantares, algo lúdico está embutido neste desejo, uma "brincadeira" para recuperar e voltar a ser e sentir a menina de outrora. Foi uma brincadeira séria e lúcida, desenhou, tentou verbalizar, não conseguiu, redesenhou, cuidou primorosamente da obra final, deixando-a imagética. A imagem é um recurso desesperado contra o silêncio que
nos invade cada vez que tentamos exprimir a terrível
experiência do que nos rodeia e de nós mesmos. (PAZ,
1972, p.48)

O Cântico dos Cânticos é uma obra aberta, de inúmeras possibilidades, pois como diz Santaella (1999, p.53) "a semântica da imagem é particularmente polissêmica". Haja vista que vários estudos já foram realizados sobre essa obra e, ainda assim, continua suscitando novos olhares, novas investigações.

Lima (1979, p. 19) afirma que:

se durante a experiência estética, o sujeito apenas confirma seu prévio horizonte cognoscente, a experiência, enquanto estética, fracassa, pois o sujeito excluirá o objeto, não será capaz de tematizar o que nele é rebelde a seu prévio estoque de saber.

Essa rebeldia ao estoque de saber nos move, faz com que a obra mantenha sempre um frescor de encantamento, possibilitando, para o 
mesmo leitor, leituras diferentes em momentos diferentes, isso se deve às várias combinações possíveis nos diversos níveis, seja o da significação ou representação, o da referência ou da interpretação; tais aspectos serão estudados para melhor entendermos a complexidade da obra.

\subsubsection{Olhar Representativo}

O livro, como a própria Ângela desejou, é interminável. Não é possível determinar o início e o fim, pois a capa (frente e verso) é idêntica, permitindo-nos o livre manuseio do objeto.
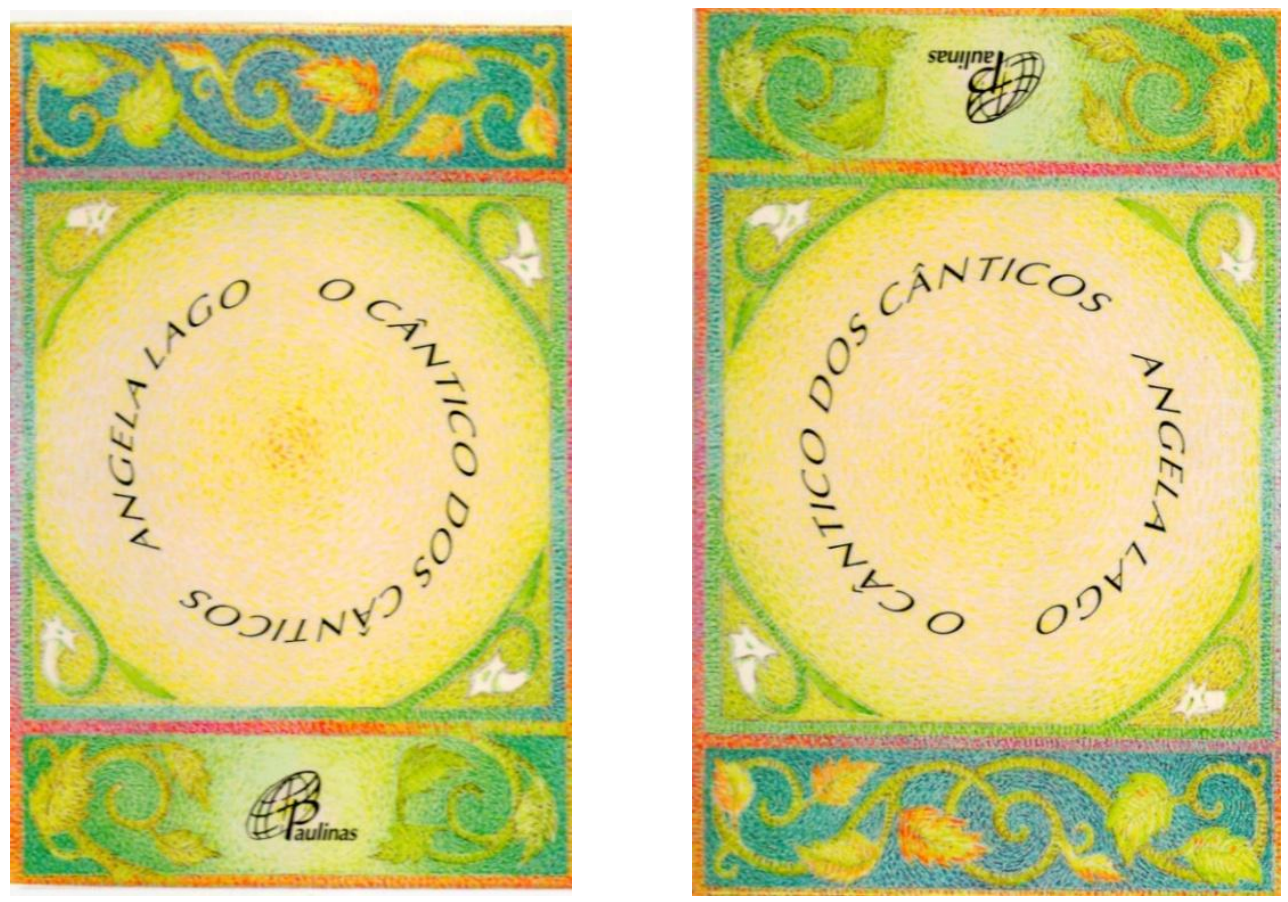

Logo nas primeiras páginas, deparamo-nos com uma folha dobrada, indicando ou sugerindo o virar das páginas e anunciando o que virá: folhagens em arabescos. 


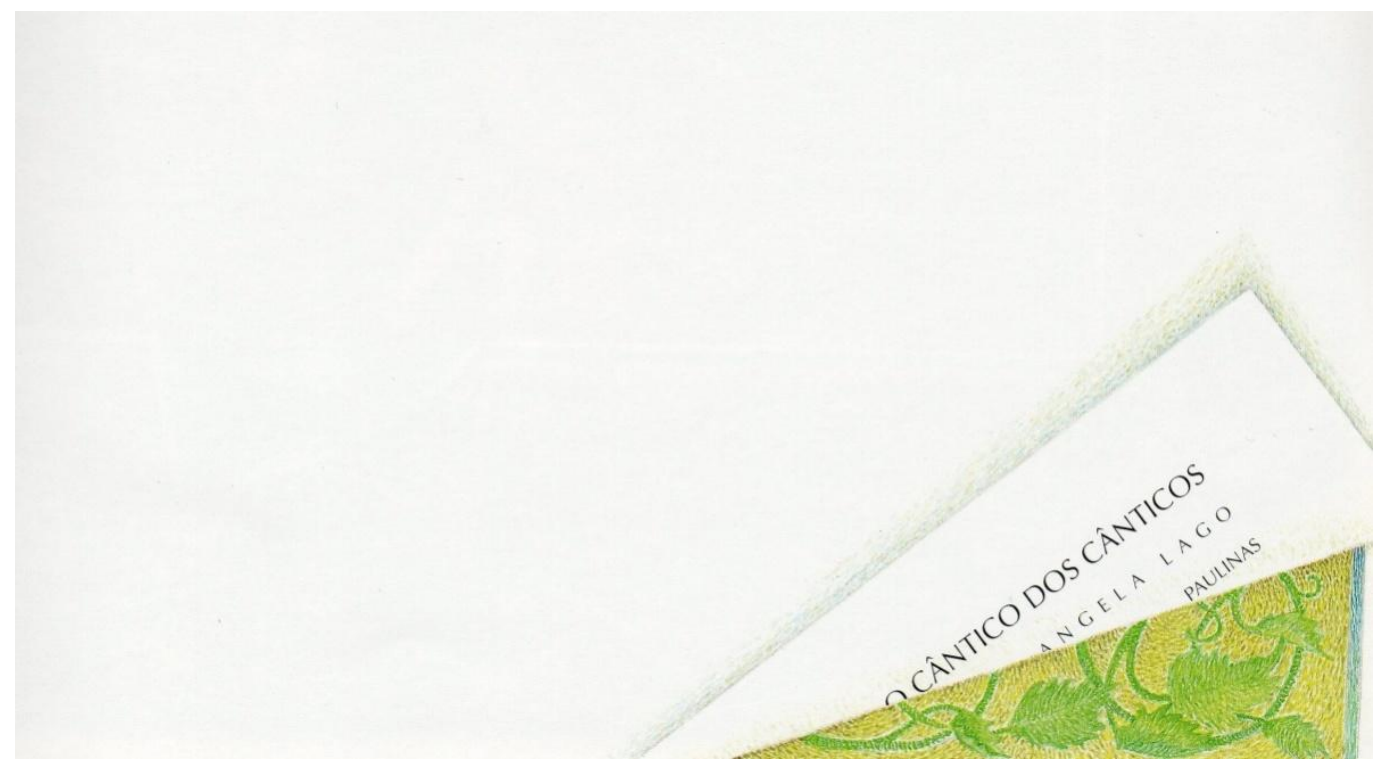

Iniciaremos o livro do lado em que a mulher se encontra à esquerda na página.

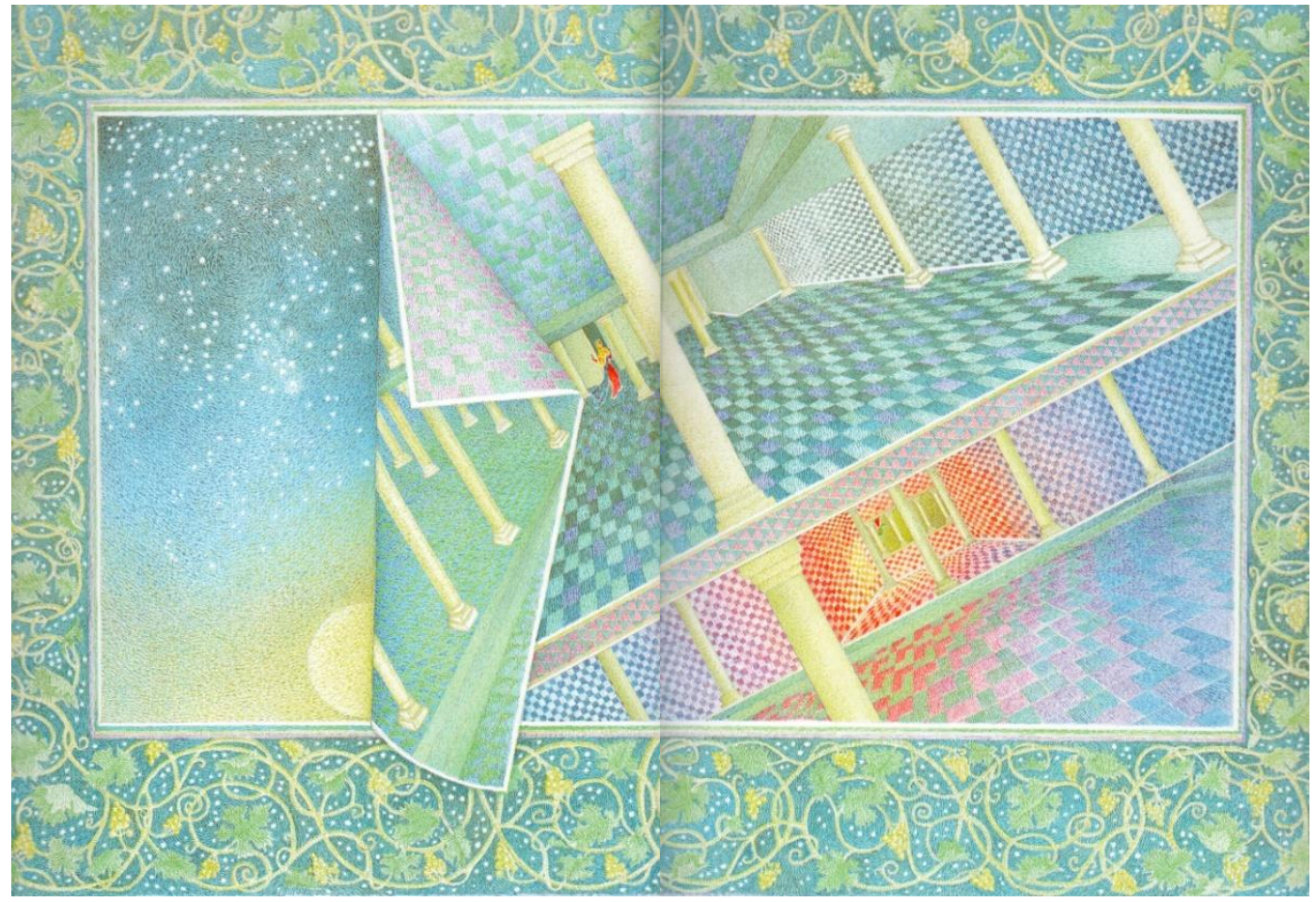

Nesta imagem podemos notar que a moldura (presente em todas as outras) tem a função de "segurar" nosso olhar, pois a imagem de dentro parece outro livro a folhear. Um livro dentro de outro livro.

A primeira moldura é ilustrada por videiras, sendo substituída nas 
páginas seguintes por flores (rosas e lírios) e volta a aparecer na última imagem.

Há uma texturização das imagens que chega a ser tátil, as cores quentes e frias foram utilizadas em gradação cuidadosa, o homem cercado geralmente por cores quentes e a mulher por cores frias.

O movimento pode ser notado tanto pelas texturas (as nervuras parecem indicar o caminho a seguir), quanto pelo esvoaçar das vestes, o folhear das imagens internas e a troca de lugares das personagens no decorrer do livro.

Colunas e escadarias instigantes estão presentes em todo o livro.

O cenário e as vestes nos remetem a um mundo oriental. Interessante notar que o tecido vermelho é o mesmo tanto da mulher, quanto do homem, algo físico que os une.

As duas primeiras imagens/cenas ocorrem no interior de um castelo talvez. Os dois (homem e mulher) se procuram. Na terceira imagem, o cenário, com suas torres, portais e muros, indicam-nos o exterior, a cidade, a vila. Os dois se aproximam cada vez mais. Embora pareça um grande labirinto, as texturas no chão indicam pistas para o encontro um do outro. 


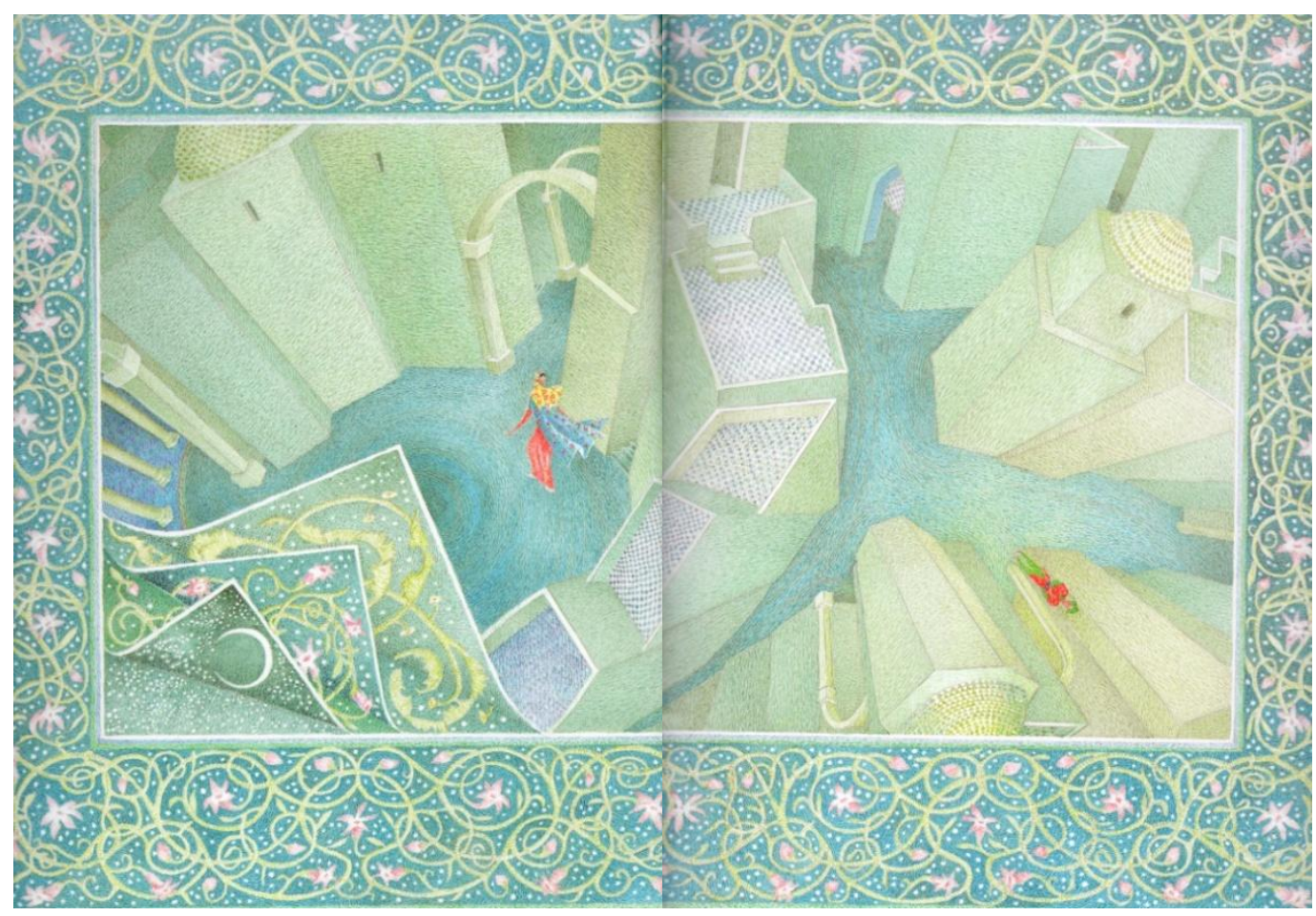

$\mathrm{Na}$ quarta imagem, os dois estão muito próximos, os gestos parecem um convite "venha" ou "vá", culminando no encontro frente-afrente (quinta imagem) num lugar alto, perto das estrelas, vários arcos guardam o local; no centro, a sensação de um redemoinho; as folhas que constituem a imagem interna parecem acompanhar esse movimento mais enérgico.

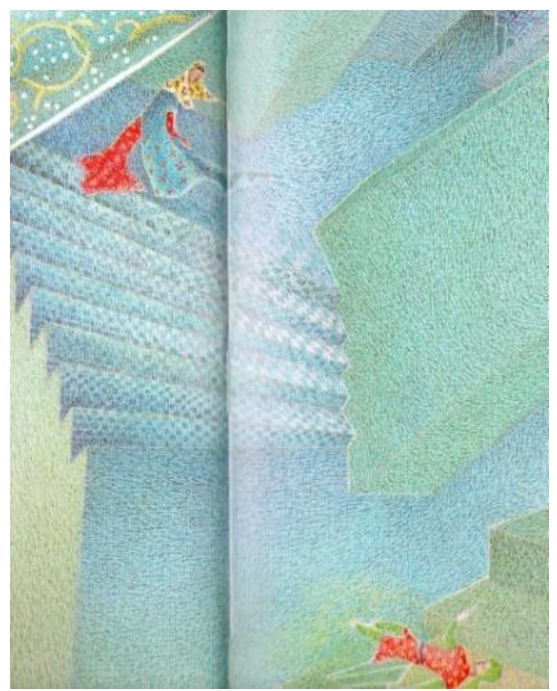

Quarta imagem

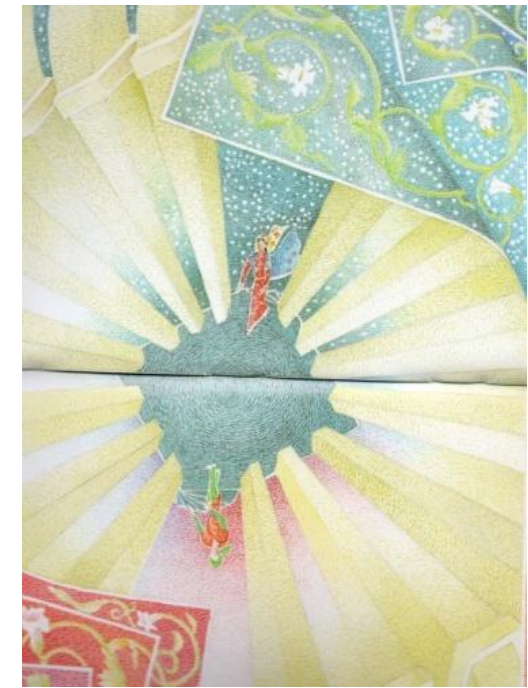

Quinta imagem 
Chegamos ao centro do livro, há um frenesi de cores e movimentos. As cores são quentes, luminosas, chegando a ofuscar nosso olhar, as folhas internas extrapolam a moldura, a união fulminante dos amantes.

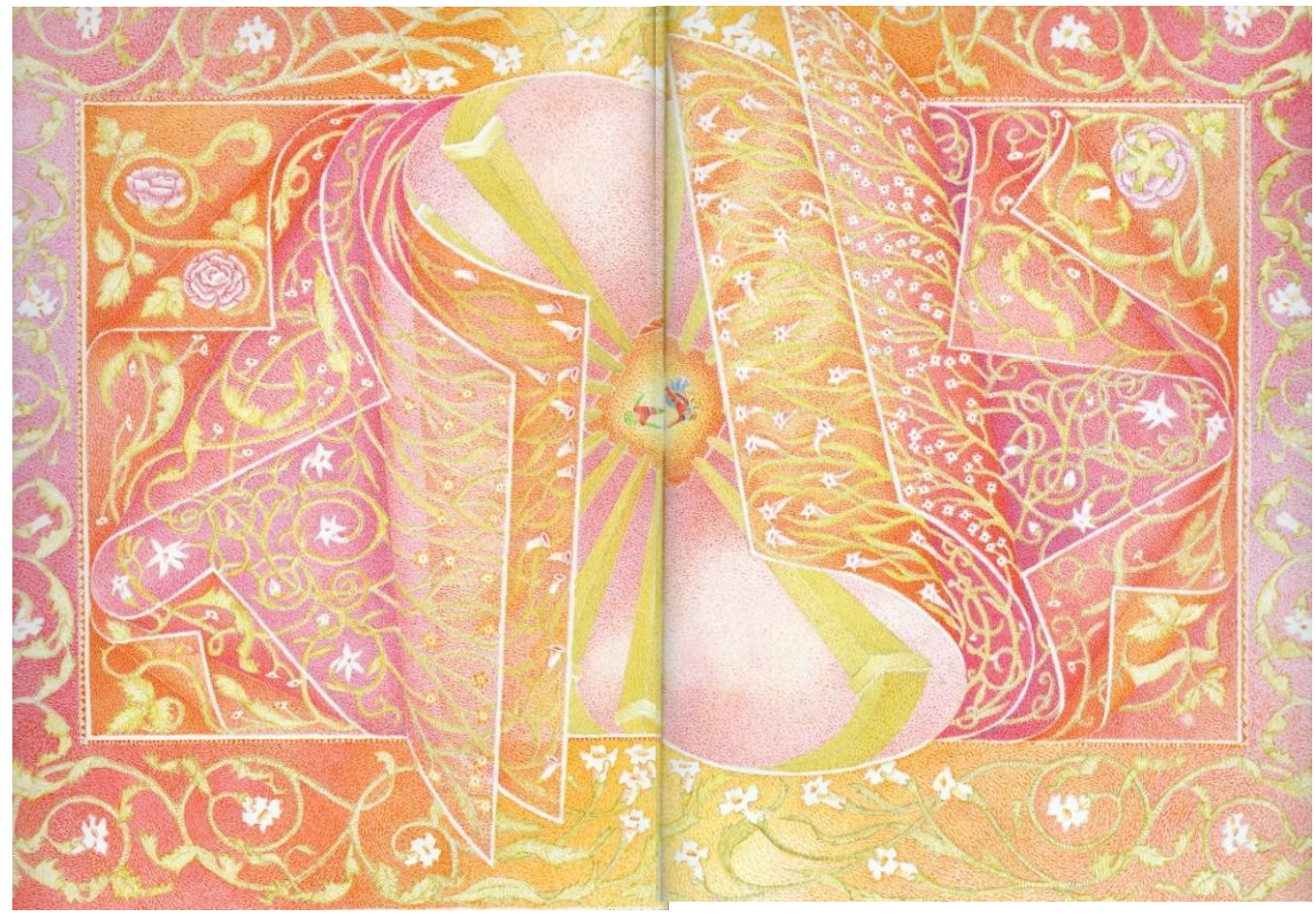

Na sétima imagem, o desenlace dos corpos e apaziguamento, as folhas voltam a ser emolduradas, as cores voltam a ser quentes e frias.

Nas oitava e nona imagens, a separação, mas sempre um olhando/cuidando do outro. As cores são amenas, igualmente em um e outro. 


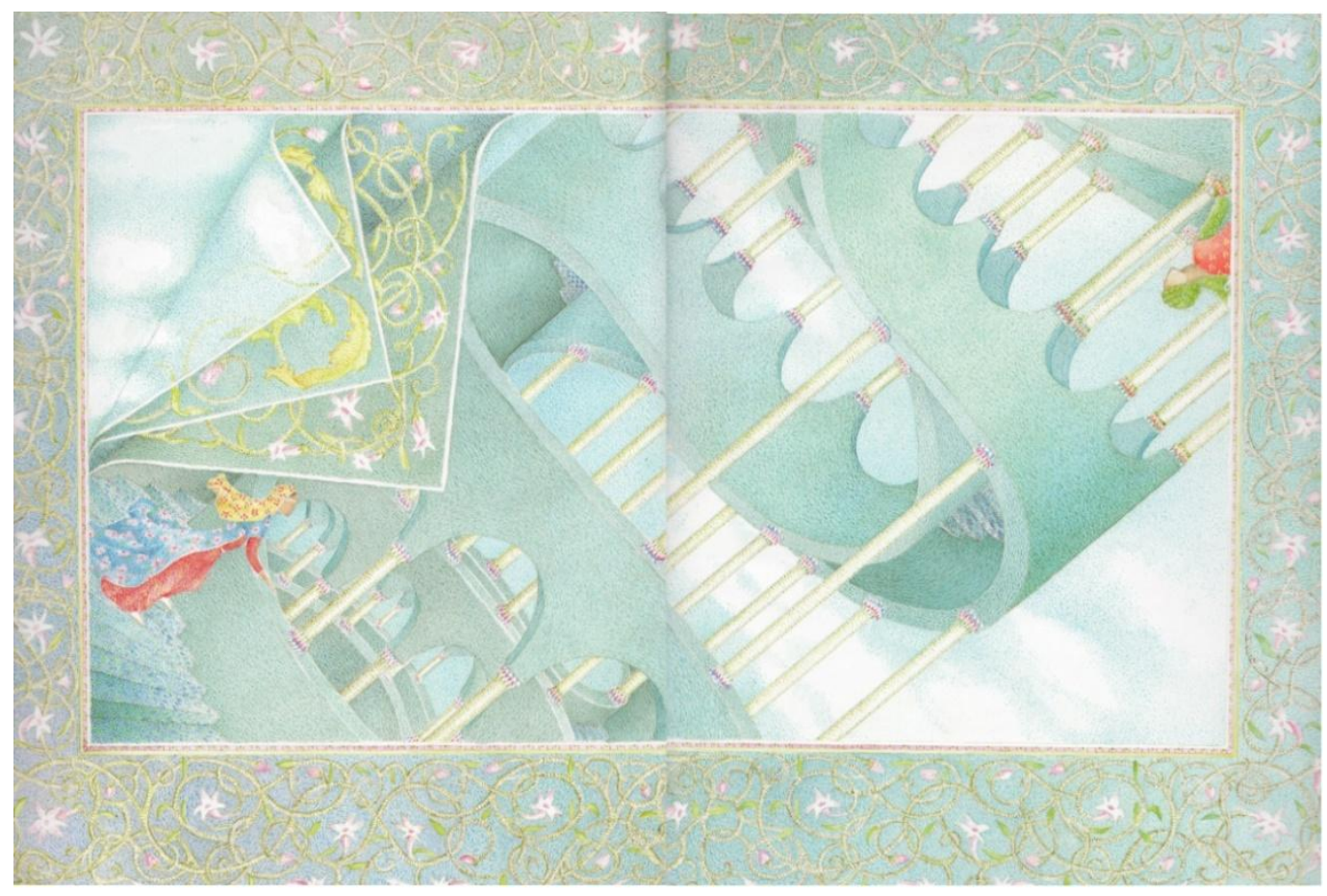

Nona imagem

Na penúltima imagem, o labirinto novamente, as cores voltam a caracterizar tanto a figura masculina (quentes) quanto a figura feminina (frias).

Na última imagem, as cores se acentuam novamente, os dois estão em sentidos opostos, mas o olhar os une.

O contraste é necessário para que a vida, plena de sensações e emoções, se faça presente.

[o contraste] desequilibra, choca, estimula, chama a atenção. Sem ele a mente tenderia a erradicar todas as sensações, criando um clima de morte e de ausência de ser. (DONDIS, 1991, p.108)

\subsubsection{Olhar Referencial}

Estudar a obra em sua referencialidade significa verificar quais 
referências a autora utilizou para a realização de seu trabalho. Observar esses aspectos é importante para que nossa incursão pelo livro seja provida de vestígios reconhecíveis, para que o processo cognitivo de relações e inter-relações seja engendrado.

O Cântico dos Cânticos de Ângela Lago é uma transmutação de "Cântico dos cânticos de Salomão", que são cantares pertencentes à Bíblia. Esses poemas foram escritos em hebraico, há quase três mil anos, e o sentido de muitas palavras e expressões já se perdeu há muito tempo ${ }^{18}$.

Não se sabe com exatidão quem os escreveu embora, muitas vezes, a autoria seja atribuída a Salomão, é pouco provável que seja verdade, pois estudos contemporâneos datam o texto de uma época posterior. Enfim, são hipóteses que, de forma alguma, maculam a beleza desses poemas, pelo contrário, todo o mistério torna-os mais instigantes.

Segundo o rabino Henry I.Sobel,

no judaísmo, o sexo e o amor unem-se indissoluvelmente. 0 termo ahavá é empregado tanto para os aspectos físicos do amor como para os espirituais. Os teólogos cristãos utilizam duas palavras gregas distintas para o amor: Eros, o amor carnal, e ágape, o amor espiritual. O judaísmo insiste que o amor a Deus, o amor ao próximo e o amor entre homem e mulher são todos iguais: ahavá ${ }^{19}$

Para Ascher ${ }^{20}$

18 ASCHER, Nelson. Cântico dos Cânticos: familiaridade e estranheza. Cântico dos Cânticos de Salomão. Trad. Antonio Medina Rodrigues. São Paulo: Labortexto Editorial, p.9-25, 2000.

${ }_{19}$ In: Cântico dos Cânticos de Salomão. Traduzido do grego por Antonio Medina Rodrigues. São Paulo: Labortexto Editorial, 2000.

20 ASCHER, Nelson. Cântico dos Cânticos: familiaridade e estranheza. Cântico dos Cânticos de 
O Cânticos dos cânticos é um ciclo de poemas eróticoamorosos que lança mão de recursos potencialmente universais, refere-se a uma esfera que caracteriza toda a espécie humana e dirige-se a todo e qualquer leitor não importa a que civilização ou época ele/ela pertença.

Afinal, o Amor é universal e atemporal.

Vejamos agora as molduras, claras referências a Willian Morris (1834-1896), artista e escritor inglês.

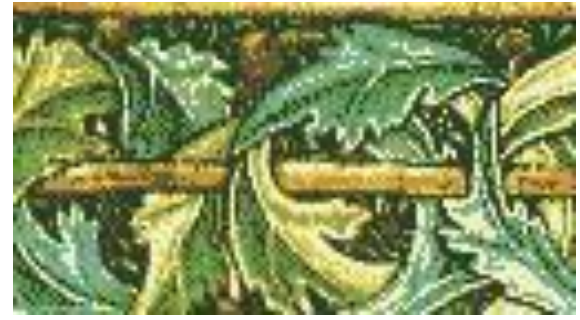

Willian Morris. Horace

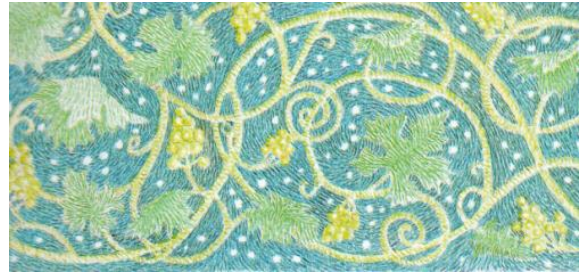

Ângela Lago. O Cântico dos cânticos

Em ambas as figuras, o traço é bem semelhante, o entrelaçamento herbáceo sugere um recurso utilizado para indicar a infinitude, visto que não há início nem fim.

Outra referência que Ângela faz em seu livro é Escher (1890-1972), artista holandês

reconhecido pelo seu incrível talento artístico em misturar elementos de surrealismo com elementos de matemática além de sua incrível técnica em xilografia e litografia. Gostava de trabalhar desenhos com Ilusões de Espaço e Formas, Prédios Impossíveis e Mosaicos Geométricos Infinitos. ${ }^{21}$

Notamos sua influência nas escadarias e colunas que desafiam

Salomão. Trad. Antonio Medina Rodrigues. São Paulo: Labortexto Editorial, 2000. p.18.

${ }_{21} \mathrm{http}: / /$ orbita.starmedia.com/necrose/Escher/Escherbiografia.htm 
nossa perspectiva,

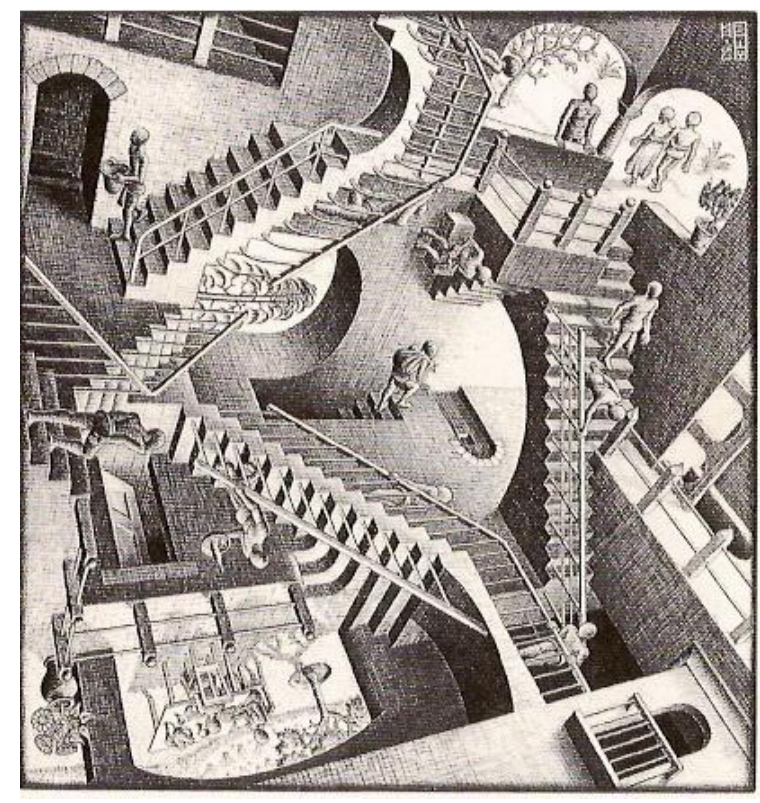

Escher. Relativity.

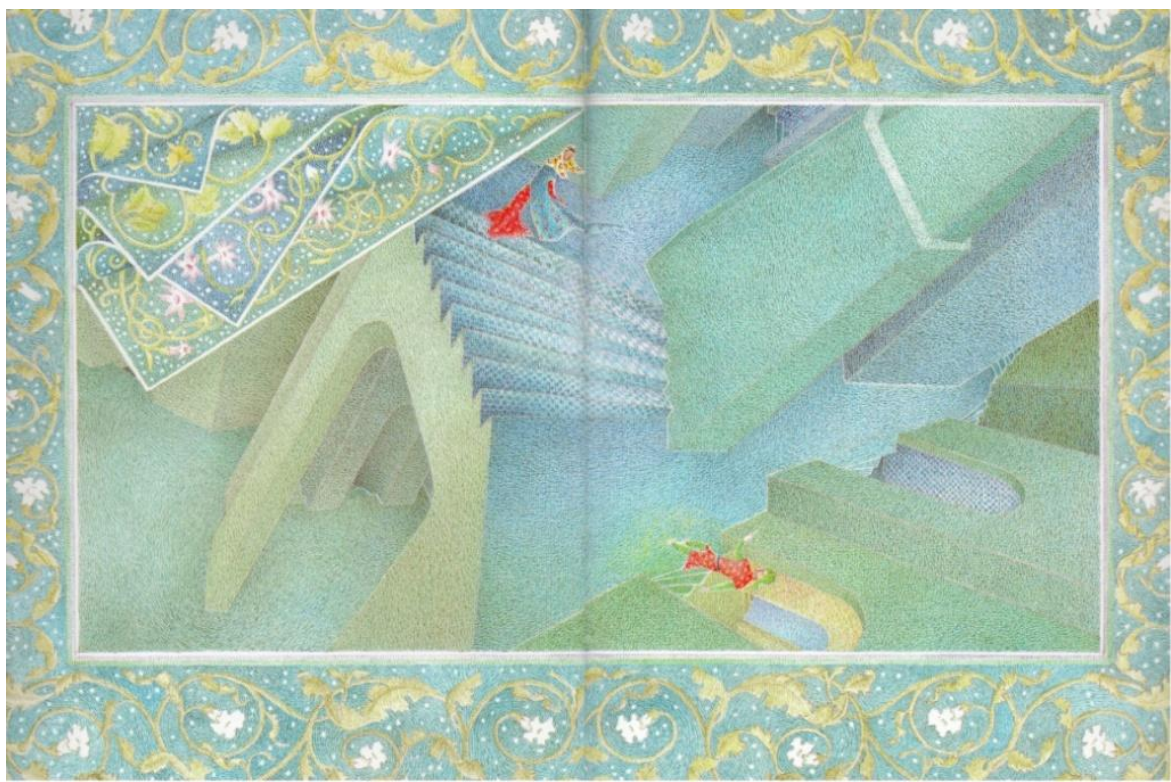

Ângela Lago. O cântico dos cânticos 

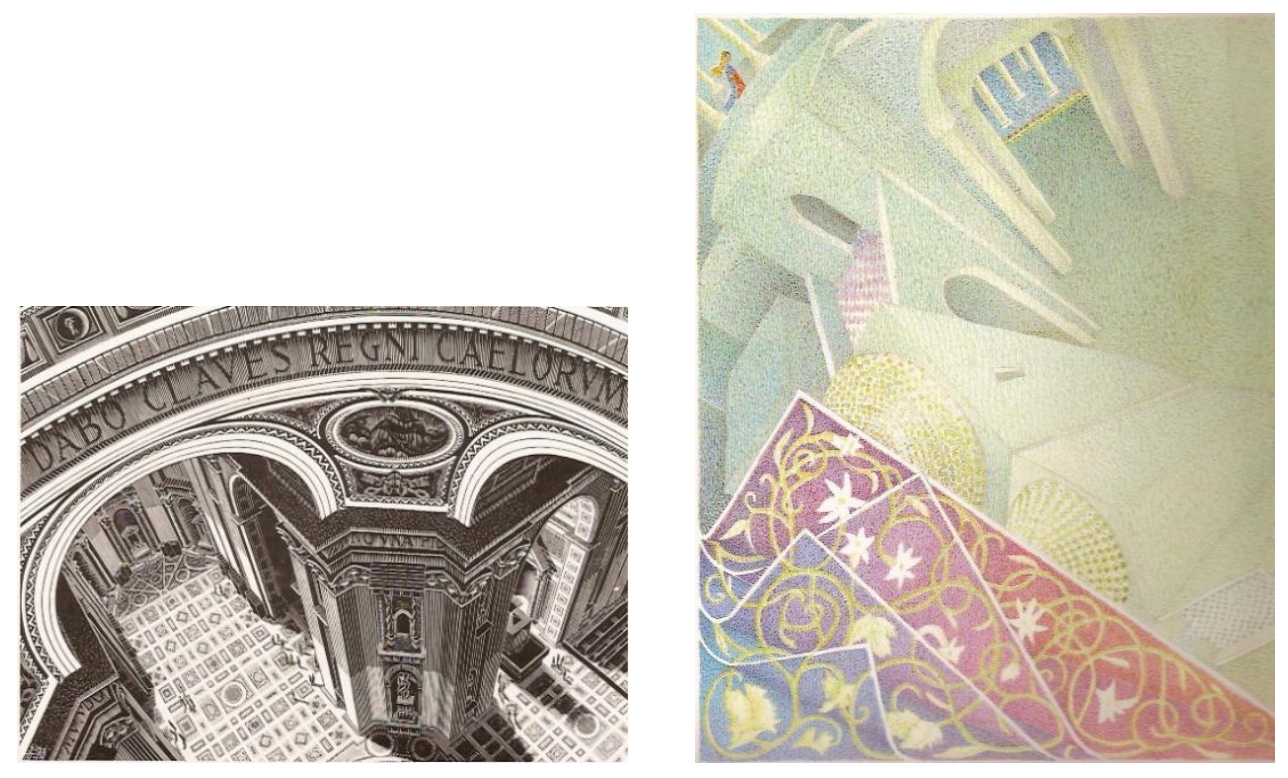

Ambos, Ângela e Escher, exploraram ao máximo o infinito possível, intrigando-nos a cada novo olhar.

\subsubsection{Olhar Simbólico}

"O Cântico dos Cânticos" de Ângela Lago é uma obra imagética e a cada novo olhar, uma inquietação nos é causada pela profusão de cores, formas, perspectivas, símbolos.

As três categorias peirceanas (primeiridade, secundidade e terceiridade) se inter-relacionam dinamicamente, não há uma classificação única e definida do signo, que pelas suas características, pode ser identificado mais contiguamente com uma ou outra categoria, mas não exclusivamente.

Conforme Santaella (1999, p.44) "a eficácia emocional das imagens cresce com o grau de sua iconicidade", o livro se encontra, então, num elevado grau de iconicidade, pois, a cada leitura, as imagens extáticas provocam nossos sentidos e emoções mais profundos. 
Não são apenas a percepção e o gozo que estão presentes. Há também o desenvolver de um processo cognitivo através das sensações.

Podemos dizer que a obra é uma terceiridade, na medida em que as possibilidades de reflexão, o vir a ser estão latentes em toda obra; carregada de primeiridade, o frescor, a liberdade, o singular e mediada pela secundidade, o êxtase, as reações frente ao signo.

Santaella define qualidade estética como:

A impressão total inanalisável de uma razoabilidade que se expressou numa criação. É um puro Sentimento, mas é um sentimento que é a Impressão de uma Razoabilidade que Cria. É uma primeiridade que realmente pertence à terceiridade na sua realização da secundidade.

(1992, p.181)

A qualidade estética da obra é inegável, dada suas inúmeras possibilidades de leitura e entendimento.

Como iniciamos a leitura desse livro? É um livro, como desejou a autora, interminável, uma leitura circular.

Já que tocamos e acordamos a palavra "círculo"22, cabe lembrar que este representa o universo, a união cósmica de todos os seres, o aperfeiçoamento interior, o infinito possível. Esse processo está presente não só na leitura física do livro, como também nas imagens, já que em todas elas há indícios de um espiral sem fim, seja nas texturas utilizadas ou na disposição espacial da cena.

Apenas por questões metodológicas, começaremos a leitura e o 22 As informações sobre simbologia se basearam no livro: CHEVALIER, Jean. Dicionário de símbolos. 2ª̣ed. Rio de Janeiro: José Olympio,1989. 
estudo do livro em que a mulher busca o homem.

Observando o livro como um todo, percebemos um espelhamento das molduras, ou seja, a primeira e a última imagem utilizam as videiras, a segunda e a décima, as rosas, as outras molduras são lírios.

O espelho é algo interessante, pois ao refletir minha imagem, sei que sou eu, mas ao mesmo tempo não sou eu que estou ali, pois estou aqui. Ser, concomitantemente, eu e o outro é um jogo recorrente em toda a obra.

Simbolicamente, a videira é considerada árvore sagrada, divina; matéria-prima do vinho utilizado em rituais de iniciação. Não é por acaso que a primeira moldura seja a da videira.

Iniciação amorosa? Iniciação espiritual? Quem sabe ambas.

A rosa simboliza o amor, a alma, a taça da vida. O lírio é a pureza, a singeleza, a promessa de salvação.

A seqüência em que as molduras aparecem nos sugere um ritual: primeiro, o rito iniciático (vinho); segundo, a devoção (o amor) e terceiro, a pureza alcançada (salvação). A tríade se faz presente novamente.

As iluminuras são infinitas, não há um começo e um fim, as videiras, as rosas e os lírios se emaranham num processo infinito, assim como a leitura e o manuseio do livro.

Há pilares por toda a cena, simbolicamente, representam a relação, a ponte, a ligação entre os diversos níveis do universo e do eu, a passagem da energia cósmica, vital ou espiritual. O elo entre o humano e o sobre-humano, o carnal e o espiritual. 
Podemos notar essa conjugação nas cores das vestes das personagens. Tanto o homem como a mulher têm o vermelho nas vestes que indica o princípio da vida; o homem carrega o verde, cor humana, da força, a mulher usa o azul, cor etérea, tranqüilidade altaneira e também o amarelo, a luz, dar a luz a uma nova vida. Enfim, há algo comum entre os dois (vermelho), há algo que os distingue (verde / azul) e há um terceiro elemento pertencente somente à mulher, a dádiva de iniciar uma nova vida.

Na maioria das imagens, a mulher está envolta em cores frias, a noite, o luar, o subjetivo, a emoção, o yin; o homem, em cores quentes, o dia, a objetividade, a razão, o yang. São opostos que se complementam, portanto, necessários.

Na segunda moldura há algo que intriga nosso olhar: uma lua crescente emaranhada entre as rosas. Na terceira imagem aparece a lua minguante, não na moldura externa, mas na imagem de dentro.

Lua crescente e minguante indicando o ritmo biológico, o início e o fim, a renovação cíclica: crescer, aumentar e minguar, diminuir.
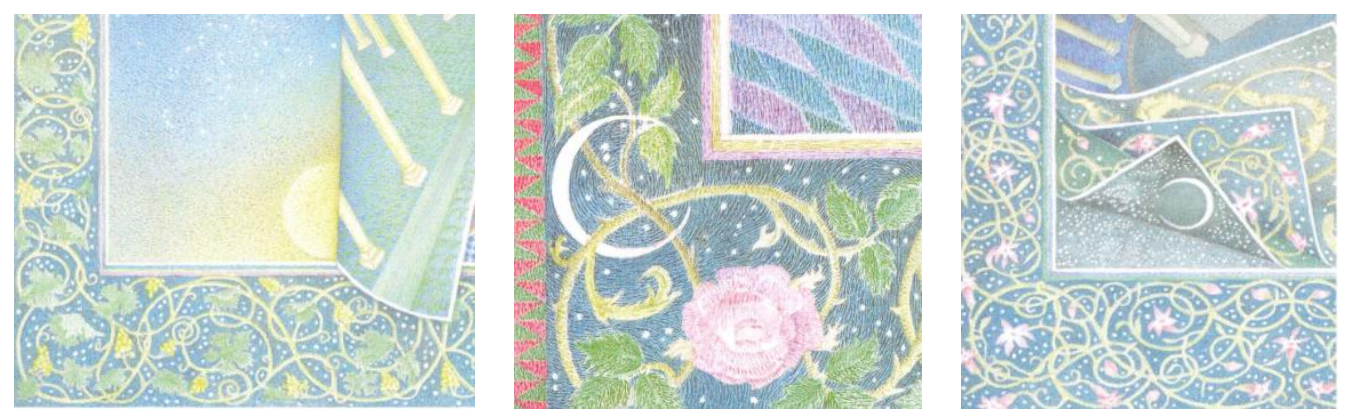

As escadarias estão presentes em várias imagens e simbolizam a progressão, a ascensão, a transfiguração. Segundo Chevalier "a escadaria pode designar não apenas a subida para o conhecimento, mas uma 
elevação integrada de todo o ser", sugerindo a busca de algo, representado, no livro, por alguém.

Quando se chega a esse estágio de transfiguração, chega-se ao centro do livro, o momento mais extático, orgástico. Todas as energias culminam no encontro dos amantes, o esvoaçar frenético das folhas internas, as cores luminosas, tudo corrobora para a perfeição circular alcançada. Este é o momento em que o ying e o yang se encontram, formando o "todo", é a integração das partes, a semiose alcançada.

Logo depois, a separação. Os amantes, ainda ofegantes, se separam.

Nas oitava e nona imagens, não há predominância de cores quentes e frias sobre as personagens, indicando, talvez, o tempo para repor as energias vitais e individuais, que os amantes necessitam para recomeçar a busca sem fim.

A obra, como um todo, ativa todos os nossos cinco sentidos tradicionais (visão, paladar, tato, audição e olfato) e, mais contemporaneamente, o sexto sentido: o cósmico.

Nesse caso, a visão é soberana, é através dela que acionamos todos os outros sentidos. São enigmas cromáticos, construções inusitadas que nos fisgam e extasiam-nos a todo instante.

Logo na primeira moldura, nosso paladar é provocado pela imagem das videiras que sugerem o vinho, iniciando um ritual de sensações e percepções.

As texturas utilizadas dão-nos a impressão de algo que se sobressai, 
não algo chapado na folha de papel, sendo irresistível tentar tocar as irregularidades das mesmas, a sensação tátil.

Pelos gestos corporais das personagens, as sutilezas no levantar das mãos, a posição dos pés e os olhares, sugerem-nos um passo de dança. É possível quase ouvir uma música, no início um ritmo mais lento que se acelera gradativamente chegando ao clímax no centro do livro, depois, o ritmo novamente se acalma. Seria uma dança circular? Talvez, pois tem como princípio a confluência de todas as energias: positivas e negativas, ying e yang. A obra, da mesma forma, trata das oposições complementares.

Os motivos de rosas e lírios nas molduras deixam a obra perfumada. Os aromas nos inebriam e parecem nos conduzir a uma esfera quimérica.

Por fim, o sentido cósmico: o sentido da vida e do Universo. A eterna procura do outro e de nós mesmos, o encontro, após várias provações e desencontros; a separação necessária para que a procura continue, de forma cíclica. Assim como tudo na vida, não se pode viver em ininterrupta felicidade ou alegria, são apenas momentos, que vêm, passam e voltam. Novamente a tríade: a procura, o encontro e a separação.

Pound (1976, p.23) já dizia "só a emoção perdura", diante desta obra que é pura emoção, desde a concepção mental da autora, resta-nos dizer que certamente ela perdurará. 


\title{
3.4 Poesia e jogo
}

\author{
"Quando escrevia, não kinha a preocupação de ensinar uma mensagem. [...] \\ Que negácio é esse de alguém me dizer o que eu tenho que entender? $\mathcal{E}$ o que eu \\ kenho dentro da minha cabeça, por acaso sou idick? Deixa que eu entendo soginha. \\ The contem a história que eu entendo do meu jeito. Educativo, didático, hudo isso não \\ passava de blábláblá, en não queria nada disso. Deixem a criança usar a própria \\ cabec,a." Jakiana Belinky
}

Como jogo, a arte poética instaura um momento de invenção o qual libera potencialidades da memória, da percepção, da imaginação engendrando novas armações, novas sintaxes. E o poeta inventa o quê e como fazer. É o que vemos no livro Mandaliques, em que Tatiana Belinky ressignifica brincadeiras utilizando os limeriques, segundo a própria autora "a idéia é ressaltar uma coisa que é o contrário do que penso, e a criança, que não é nada boba, vai entender direitinho"23. As palavras em suas mãos virão jogos e com a leitura inicia a divertida brincadeira poética.

Como diz Huizinga (2004), os múltiplos arranjos dos mesmos elementos e a irrupção do acaso em uma ordem pré-fixada em espaço e tempo imaginários fundem brincadeira e seriedade. Só a imaginação criadora favorece a invenção e a apreensão dessas "belezas livres" ou montagem de palavras brinquedos que provocam o riso e reflexão.

\subsubsection{Vivendo e ... Tatianando}

Conhecer a história de Tatiana Belinky é aprender um modo todo peculiar de viver e pensar.

\footnotetext{
${ }^{23}$ http://www.revistadacultura.com.br:8090/revista/rc03/index2.asp?page=entrevista $-20 / 05 / 11$.
} 
Nascida na Rússia, veio ao Brasil com dez anos de idade. Aprendeu a ler aos quatro e, segundo ela própria ${ }^{24}$, nunca mais parou, lia vorazmente tudo o que the vinha às mãos. Seus pais, profissionais liberais, incentivavam-na a embrenhar-se no mundo da leitura e da cultura.

Tatiana trabalhou com teatro, televisão, jornal e, claro, com livros, traduzindo, adaptando, criando.

Sua vida, desde a infância, é muito dinâmica, plena de autonomia, liberdade e muito humor, características presentes no objeto escolhido para análise: "Mandaliques".

\subsubsection{O jogo representativo}

O livro ${ }^{25}$ contém quatorze limeriques com respectivas ilustrações. Somente três cores são utilizadas: preto, vermelho e branco.

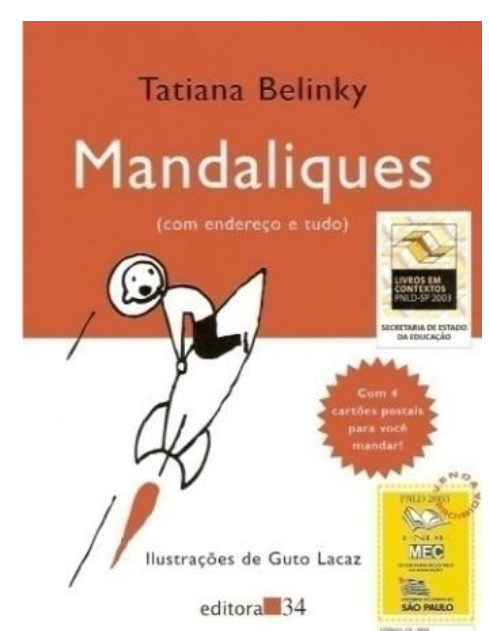

Na capa, há um homem sentado ao contrário, num foguete que se

${ }^{24}$ ROVERI, Sergio. Tatiana Belinky ... e quem quiser que conte outra. São Paulo: Imprensa Oficial, 2007.

${ }^{25}$ Em 2003 foi adotado pelo Programa Nacional do Livro Didático - PNLD - Secretaria de Estado da Educação - São Paulo. 
projeta em direção ao título "Mandaliques". O nome talvez seja uma vingança "dessa gente que vive mandando os outros para cá e para lá, para lá e para cá - como se as pessoas fossem bolinhas de pinguepongue ${ }^{\prime 26}$. Tendo em vista essa afirmação, possivelmente, o foguete pretende explodir os mandaliques, as "mandações".

O livro inova ao trazer num envelope quatro cartões-postais com os mandaliques e uma cartela com adesivos de quatro ilustrações e um desafio: descobrir onde se encaixa o verso (_ Não sei para onde ir primeiro!) e colar no respectivo mandalique. Trata-se de um livrobrinquedo. Brincar, manusear ou até enviar pelo correio os cartõespostais, fazem do livro um objeto interativo, tanto com a própria obra, quanto com outras pessoas (no caso do envio). Esse aspecto lúdico procura ser uma pausa, um recreio na vida quotidiana, como diz Huizinga (2004, p.33)

o jogo é uma atividade ou ocupação voluntária, exercida dentro de certos e determinados limites de tempo e de espaço, segundo regras livremente consentidas, mas absolutamente obrigatórias, dotado de um fim em si mesmo, acompanhado de um sentimento de tensão e de alegria e de uma consciência de ser diferente da 'vida quotidiana'."

\subsubsection{O jogo referencial}

Os mandaliques têm como referência os limericks, composição poética inglesa, cujo expoente foi Edward Lear (1812 - 1888).

O limerique é um poema bem-humorado feito de cinco versos. Os dois primeiros versos rimam com o último, enquanto o terceiro e o quarto

\footnotetext{
${ }^{26}$ BELINKY, Tatiana. Mandaliques (com endereço e tudo). São Paulo: Ed.34, 2001. p.35
} 
versos, mais curtos, rimam entre si. O esquema de rima é, então, da seguinte forma:
A
A
B
B
A

Outra referência-chave são as expressões populares de exasperação contra os mandes e desmandes das pessoas. Tais expressões aparecem sempre no último verso:

$$
\begin{gathered}
\text { _Vai para o raio que o parta! } \\
\text { _ Babaca! Vai plantar batatas! } \\
\text { _ Vai enxugar gelo! } \\
\text { _ Vai, vai para o inferno! } \\
\text { _ Vai ver se estou na esquina! }
\end{gathered}
$$

A linguagem utilizada é coloquial, informal e, sobretudo, bemhumorada. Uma linguagem escrita fronteiriça com a falada, pois além do travessão (indicação de fala), o ritmo e a entonação dão a graça, o humor dos limeriques. Tal jogo poético

lança sobre nós um feitiço: é "fascinante", "cativante". Está cheio das duas qualidades mais nobres que somos capazes de ver nas coisas: ritmo e harmonia. (HUIZINGA, 2000, p.13)

Ler a biografia de Tatiana Belinky faz entender melhor o objeto de estudo em questão: "Mandaliques - com endereço e tudo". 
Senhora de si desde criança e criança apesar de senhora. Seus pais, como já dito, proporcionaram-Ihe um ambiente favorável à liberdade, à autonomia, à ética. A leitura tornou-se hábito desde tenra idade, leitura sobre tudo e não apenas aquelas ditas, pelos adultos, próprias para meninas. Aos onze anos, ocorreu um fato muito interessante: Tatiana chegara ao Brasil e fora matriculada, primeiramente, numa escola alemã, mas não por muito tempo, o método de ensino era traumático (os alunos apanhavam). Seus pais transferiram-na, então, para uma escola americana e a primeira coisa que ela fez, foi correr para a biblioteca

Entrei naquela sala grande, procurei a maior estante $\mathrm{e}$ comecei a mexer. Mexi, mexi, mexi, escolhi um livro. Não sabia muito bem o que era, mas me pareceu interessante. $\mathrm{E}$ fui mostrar para a bibliotecária. E ela disse hã, hã, isso não é pra você. Como não é pra mim, isso não é biblioteca circulante? É, respondeu ela, mas não é para você. Como? Não é para menina, ela me explicou. Aí eu já fiquei espantada. Por que para menina? Existe livro para menina e para menino? Não é isso, é que este livro não serve para você. Mas por quê? Porque é impróprio, ela continuou. O que é impróprio? Por que existe o impróprio? Ela disse não importa, não é para você.[...] Eu me queixei para meu pai. Ele disse deixa. Sentou e escreveu um bilhetinho em português castiço, perfeito para a bibliotecária: Minha filha Tatiana está autorizada a retirar da biblioteca o livro que ela quiser". ${ }^{27}$

Permitimo-nos transcrever a extensa citação acima para que ficasse clara a dimensão de liberdade e autonomia em que a autora viveu desde a infância, características tão presentes em toda sua vasta obra e, particularmente, em Mandaliques - com endereço e tudo.

27 ROVIERI, Sergio. Tatiana Belinky... e quem quiser que conte outra. SãoPaulo: Imprensa Oficial, 2007.p.67-68, grifo do autor. 


\subsubsection{O jogo de sentidos}

O livro Mandaliques - com endereço e tudo é um livro de poemas bem-humorados. As palavras tomam uma dimensão outra: a do jogo e da brincadeira.

Huizinga (2000, p.12) afirma que o jogo

Ornamenta a vida, ampliando-a, e nessa medida torna-se numa necessidade tanto para o indivíduo, como função vital, quanto para a sociedade, devido ao sentido que encerra, à sua significação, a seu valor expressivo, a suas associações espirituais e sociais, em resumo, como função cultural. (grifo nosso)

Góes (1984) coloca que a arte, a obra literária deve proporcionar, antes de tudo, o prazer, pois caso contrário, será apenas didática, no sentido estreito e restrito: o de apenas ensinar. Posição criticada também pela própria autora Tatiana Belinky, que repudia as "morais" das histórias, os ensinamentos "didáticos" prontos, ou seja, quando não há espaço para a criança pensar, refletir o que é bom ou não, os adultos já Ihes dizem "é isso".

A obra em questão segue caminho inverso ao colocado acima. Portanto, a leitura lúdica, além de brincadeira prazerosa e divertida é essencial para a constituição do ser humano, na medida em que, em nossa vida rotineira são necessários momentos de intervalo, de descontração.

No livro, não há a preocupação de ensinar algo pronto, mas encontra-se um apelo à reflexão, posto constituir-se em um desabafo 
humorado e uma crítica velada àqueles que vivem mandando e desmandando. "O humor é uma das maiores armas da poesia".(PAZ, 1982, p.48).

O riso é obtido por meio de situações inusitadas:

\author{
Em turma, uns cinco velhacos, \\ Zurrando e coçando os sovacos, \\ Chegaram zombando \\ E me enxotando:
}

_ Dá o fora, vai pentear macacos!

As ilustrações fazem o contraponto do texto verbal, pois neste a palavra é utilizada no sentido figurado, irônico, enquanto as imagens mostram o sentido literal, ou seja, realmente, há um jovem pronto para pentear um macaco.

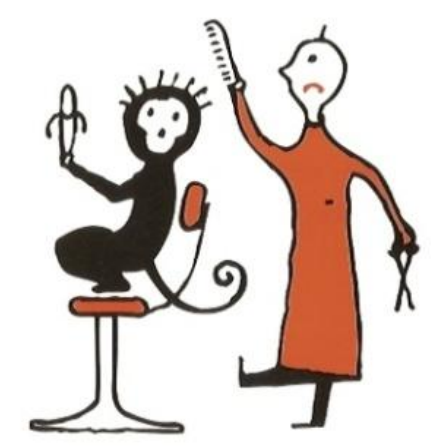

Como já foi dito, o último verso de todos os mandaliques são expressões populares, indicando, como Pound (1976, p. 37) diz: 
"A dança do intelecto ente palavras", isto é, o emprego das palavras não apenas por seu significado direto mas levando em conta, de maneira especial, os hábitos de uso, do contexto que "esperamos"encontrar com a palavra, seus concomitantes habituais, suas aceitações conhecidas e os jogos de ironia.

As cores utilizadas, vermelho, preto e branco, indicam os opostos, o conflito (as duas primeiras) e o equilíbrio, o apaziguamento (a terceira). 0 olhar não se sobrecarrega com a tensão (preto/ vermelho) pois a mesma é quebrada pela neutralidade do branco. Dondis (1991, p.108) coloca que "o contraste é um poderoso instrumento de expressão, o meio para intensificar o significado, e, portanto, simplificar a comunicação".

As ilustrações são compostas por traços reduzidos aos indispensáveis para o entendimento. Esse nível imagético é definido por Dondis (1991, p.90) como "abstração":

O processo de abstração é também um processo de destilação, ou seja, de redução de fatores visuais múltiplos aos traços mais essenciais e característicos daquilo que está sendo representado.

Para o autor, em termos visuais "a abstração é uma simplificação que busca um significado mais intenso e condensado." (idem, p. 95) 

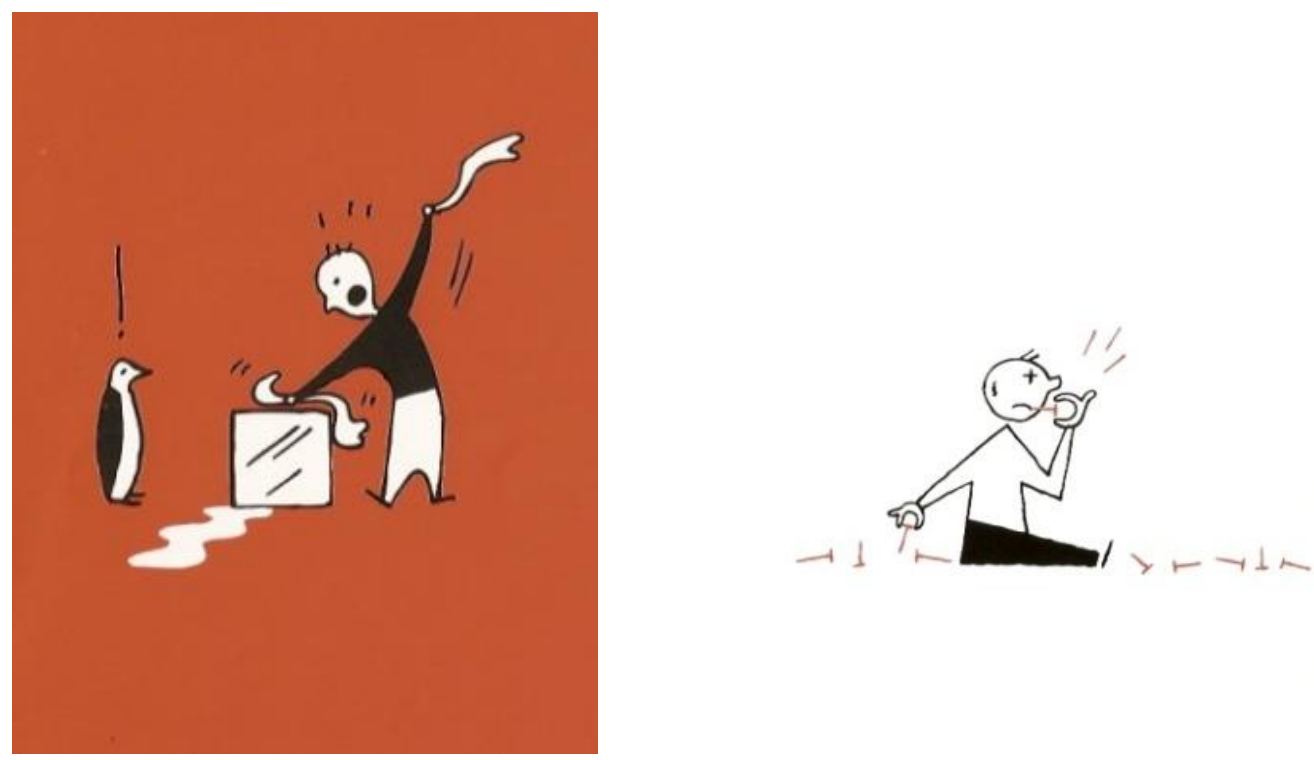

As crianças, geralmente, desenham dessa forma, o essencial já é o suficiente, os detalhes são apenas detalhes.

No início do livro, bastam as marcas dos passos cruzando uma ponta à outra, formando um grande "xis" que significa "errado, não condizente", para entendermos a mensagem: os mandes e desmandes nunca mais, servindo como anúncio para o que virá nas páginas seguintes.

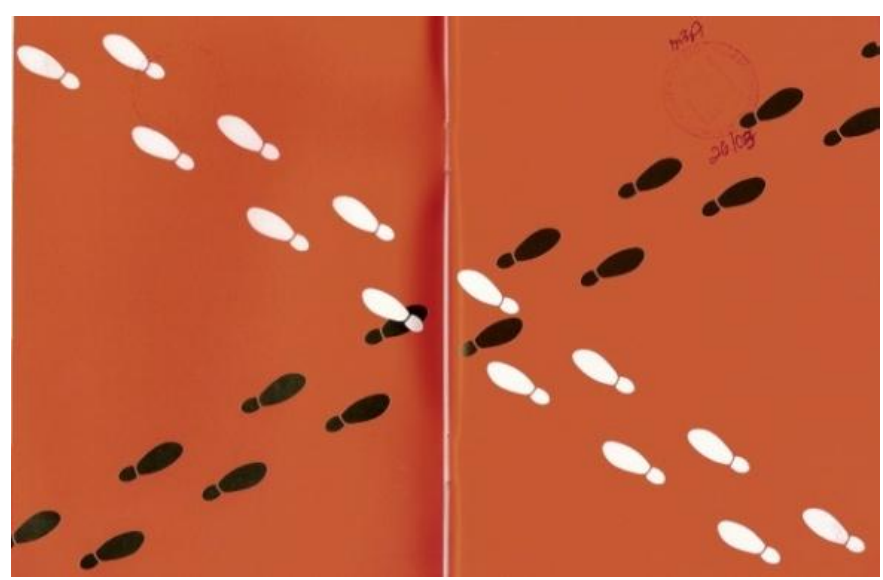

Texto verbal e imagem formam uma simbiose peculiar, quando opostos se complementam para formar um terceiro sentido, ou seja,

No caso da disposição lado a lado do texto e da imagem, não se trata de uma mera adição de duas mensagens 
informativas diferentes. Uma nova interpretação holística da mensagem total pode ser derivada dessa disposição. (SANTAELLA, 1999, p. 55)

Ler literalmente e entender figurativamente envolvem processos ativos de percepção e compreensão. Sensação, memória e atenção em sintonia estimulam inferências a partir das relações estabelecidas entre o texto verbal e o imagético. O humor se faz presente no jogo entre os códigos das duas linguagens e na leitura que envolve ludicamente o leitor no jogo com os níveis do figurado e do literal. Portanto, se faz presente o leitor movente (conforme explicitado no capítulo anterior) aquele para o qual a leitura do texto transita por diferentes linguagens.

Santaella classifica as matrizes de linguagem e pensamento da seguinte forma: a sonora tem correspondência com a primeiridade, a visual com a secundidade e a verbal com a terceiridade.

A obra, em análise, apresenta as três matrizes de forma enleada, possibilitando a hibridização das linguagens.

Temos a linguagem verbal no próprio limerique; a visual, nas ilustrações; A linguagem sonora está presente potencialmente, ou seja, os limeriques pedem para serem lidos, o jogo, o humor são mais fortes, quando verbalizamos em voz alta. São três linguagens que brincam o tempo todo, uma procurando a outra para formar uma combinação que resulte em riso e descontração.

Trata-se de um objeto dinâmico, que Santaella (1993, p.48) define como: 
O objeto que está fora do signo e que, pela própria natureza das coisas, o signo não consegue expressar inteiramente, podendo só indicá-lo, cabendo ao intérprete descobri-lo por experiência colateral.

Cabe ao intérprete atribuir as significações de humor presentes na obra, se o intérprete não perceber os jogos de linguagens envolvidos no processo, a leitura será ingênua e, portanto, prejudicada. Portanto, o interpretante (efeito que a obra causa ou pode causar) far-se-á presente, de forma plena, somente se o leitor estiver habilitado para jogar e brincar com as diferentes linguagens presentes na obra.

Ressaltamos que a leitura está intrinsecamente ligada ao social, à cultura de cada povo, por isso o humor próprio desses Mandaliques e dos efeitos de riso que nos causa, pode não ser o mesmo, essa cápsula de sentido paródica pode não ser entendida como tal em outra cultura, o diálogo intertextual não se faz compreender. Como diz Propp (1992, p.32) "cada época e cada povo possui seu próprio e específico sentido de humor e de cômico, que às vezes é incompreensível e inacessível em outras épocas e povos".

A todo o momento estamos jogando, as palavras são brinquedos, na medida em que atribuímos a elas sentidos diversos a fim de proporcionar prazer e divertimento, as regras de entendimento são elaboradas e reelaboradas conforme o juízo e a vontade de cada um. Pode-se ler e ver (imagem) de forma literal ou não, pode-se ler de forma irônica e ver (imagem) de forma literal, enfim, as combinatórias são várias, mas o humor permanece e cresce, na medida em que transgredimos a lógica da 
racionalidade, do previsível, seja na leitura do texto verbal, seja na leitura do texto imagético, seja nas interfaces que criam.

3.5 "O mundo é inquieto? A gente é mais"- a poesia virtual "Chá" de Sergio Capparelli e Ana Claudia Grusznski

$$
\begin{aligned}
& \text { "A rede não é um ambiente para imagens fixas, mas para a animação. Tão há mais } \\
& \text { lapsose entre a obsevvação e a morimentação. Ambos se fundem em un todo dinâmico e } \\
& \text { complexa." } \\
& \text { (Santaclla, 2007,p. 182) }
\end{aligned}
$$

\subsubsection{Interação necessária}

Para entendermos a poesia virtual é preciso que estejamos prontos para lidar com a complexidade sígnica que envolve o seu processo de criação. O texto hipermidiático, como já visto em capítulo anterior, aciona um processo de leitura diferente, em que a exploração se dá por rotas de navegação multi-lineares, cuja interação se faz presente em diversos aspectos: entre homem-máquina, entre diferentes saberes (poesia e técnica), entre pessoas diferentes.

Neste trabalho, enfocamos a obra Chá, cujo processo de criação envolveu o poeta Sergio Capparelli, a designer gráfica Ana Claudia Grusznski e o cyberstudio W3haus.

Para entendermos como se deu a parceria desses três, é necessário que se faça uma breve apresentação de cada um dos responsáveis por essa produção.

Sergio Capparelli nasceu nem Uberlândia - MG, mas considera-se 
um "quase gaúcho" por viver muito tempo em Porto Alegre-RS. Cursou o doutorado e o pós-doutorado na França, residiu em Beijing, na China, onde trabalhou em uma agência de notícias.

Embora sua formação seja em Jornalismo e Comunicação, destacouse como escritor de Literatura Infantil e Juvenil, com mais de 40 livros publicados. Ganhou diversos prêmios, como: Jabuti, da Câmara Brasileira do Livro; Açorianos, da Prefeitura Municipal de Porto Alegre; APCA, da Associação Paulista de Críticos de Arte, entre outros.

Sergio Capparelli é um poeta em constante mutação: começou com poesias verbais, depois vieram as verbo-imagéticas e, recentemente, trabalha com as virtuais.

Ana Claudia Grusznski nasceu em Porto Alegre - RS, formou-se em Jornalismo Gráfico e Audiovisual pela Universidade Federal do Rio Grande do Sul. Trabalhou em agências de design gráfico e, atualmente, leciona na UFRS.

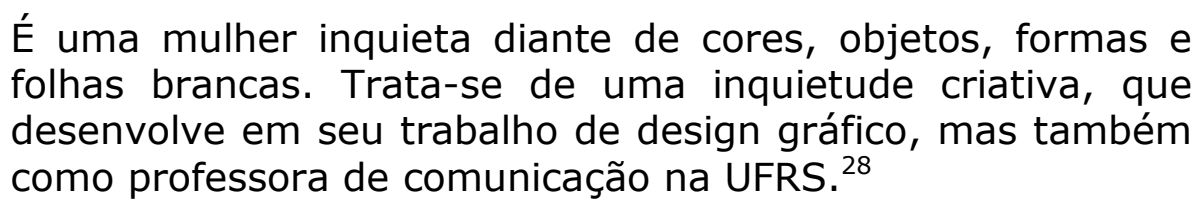

A W3haus é uma agência digital que surgiu em 2000 pela iniciativa de quatro jovens com diferentes formações: Tiago Ritter (jornalismo), Rodrigo Cauduro (arquitetura), Alessandro Cauduro (informática) e Chico Baldini (publicidade). 
O nome W3haus significa a Casa da Web, W3 em alusão ao www (world wide web) e haus, palavra alemã traduzida por casa. Atua em Porto Alegre (onde começou), São Paulo e Londres.

O conceito da agência é traduzido em seu slogan: "O mundo é inquieto? A gente é mais". ${ }^{29}$

O que uniu Sergio Capparelli, Ana Claudia Grusznski e W3haus? A inquietação, a busca pelo novo.

O resultado dessa interação, veremos a seguir.

\subsubsection{Poesia e virtualidade}

Plaza (1998, p.XV) coloca que as imagens de terceira geração ou infográficas "só podem ser compreendidas dentro do amplo quadro da trilogia homem-mundo-máquina e não mais no diálogo homem-mundo". A comunicação entre homem-mundo e homem-homem pode se efetuar, então, por meio de interfaces técnicas: a máquina. A relação dessa tríade deve ser "simbiótica, sensível, consciente e não parasitária." (PLAZA, 1998, p.XVIII), pois

Quanto mais harmoniosa e complementar a relação homeminstrumento, mais o homem leva em conta a tecnicidade e, quanto mais a considera, mais compreende 0 que 0 distingue da máquina, mais desenvolve a especificidade do ser vivo perante o mecânico. (SANTOS, 1994, p.48) 
Na obra de arte interativa "o destinatário potencial torna-se co-autor e as obras tornam-se um campo aberto a múltiplas possibilidades e suscetível a desenvolvimentos imprevistos numa co-produção de sentidos." (PLAZA, 2003, p.20)

Logo, o olhar de encantamento decorre quando o leitor reconhece a técnica utilizada e ao mesmo tempo sente prazer estar em contato com o objeto. A construção do sentido (coerência) perpassa pelo reconhecimento dos elementos constitutivos (coesão) e pelas relações que se estabelecem entre eles e as outras partes constitutivas do objeto/texto, logo, mesmo a imagem interativa tem uma gramática própria que precisa ser explorada e entendida para que a fruição seja mais crítica e menos ingênua.

Tavares $^{30}$ apresenta uma tipologia da imagem interativa, tendo como base a tríade peirceana: ícone, índice e símbolo. Logo abaixo mostraremos um quadro com a síntese das principais características de cada uma, enfatizamos que não se trata de uma denominação estanque e fechada, por vezes, o objeto pode apresentar particularidades limítrofes entre uma e outra classificação, ou ambas.

30 TAVARES, Mônica. Por uma tipologia da imagem interativa. 11ํㅡㄹ Encontro Anual da Associação Nacional dos Programas de Pós-Graduação em Comunicação - Compós 2002. 


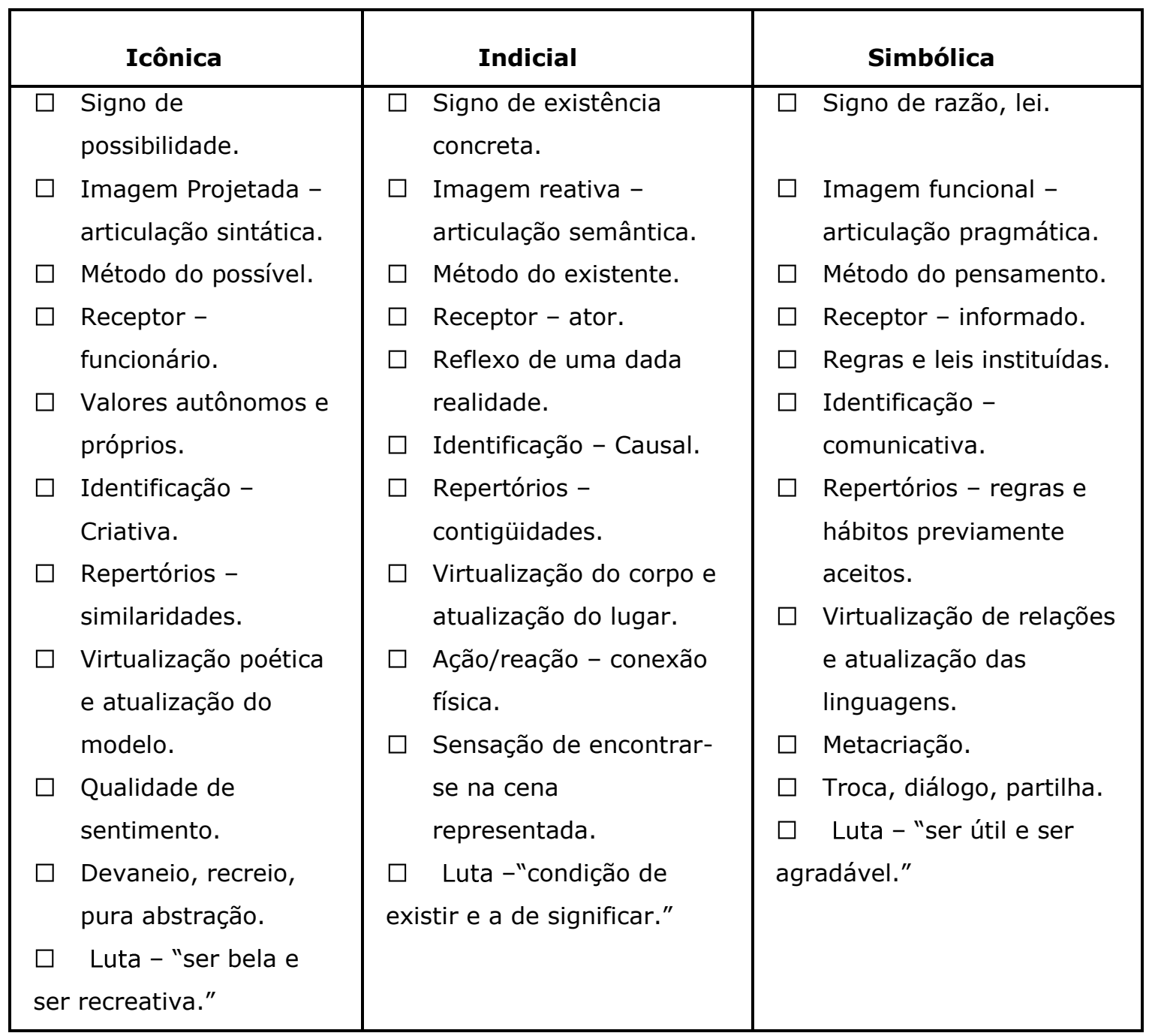

Como notamos no quadro acima, percepção e raciocínio devem estar ligados para que a potencialidade da imagem interativa possa ser explorada pelo receptor de forma plena. Em outras palavras, para o receptor que não possua ferramentas necessárias para a articulação de informações que a imagem potencializa, a obra pode ser interpretada de forma superficial, não atingindo seu objetivo de significar/ re-significar para um processo de recepção mais reflexivo e consciente.

Entender os elementos constitutivos da imagem interativa é aprofundar na leitura crítica e significativa desse complexo de mensagens sígnicas com as quais nos deparamos na rede e nas interfaces 
tecnológicas.

\subsubsection{Inquietudes virtuais}

Selecionamos para este estudo - a obra virtual - "Chá"31, como dissemos, foi construída por Sérgio Capparelli e Ana Claudia Gruszynski em parceria com a agência W3haus. A obra é um ciberpoema em que o leitor é convidado a fazer um chá com os ingredientes que desejar (corações, foto, estrelas), bastando clicar e arrastar até a xícara para que o poema-chá aconteça.

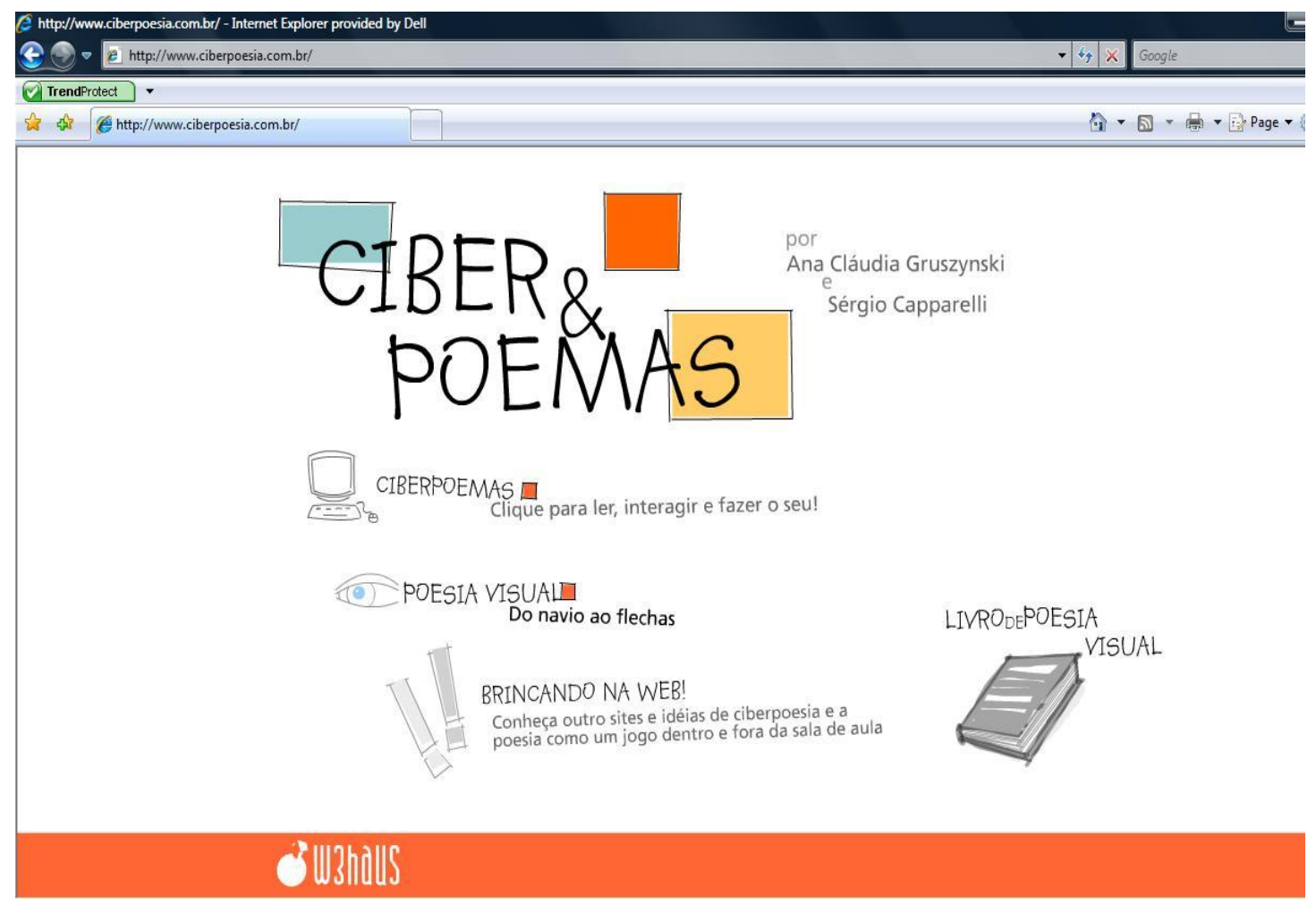

Cabe lembrar que o texto hipermidático somente se realiza, como já colocado, se o leitor navegador conhecer as técnicas básicas de acesso ao 
computador.

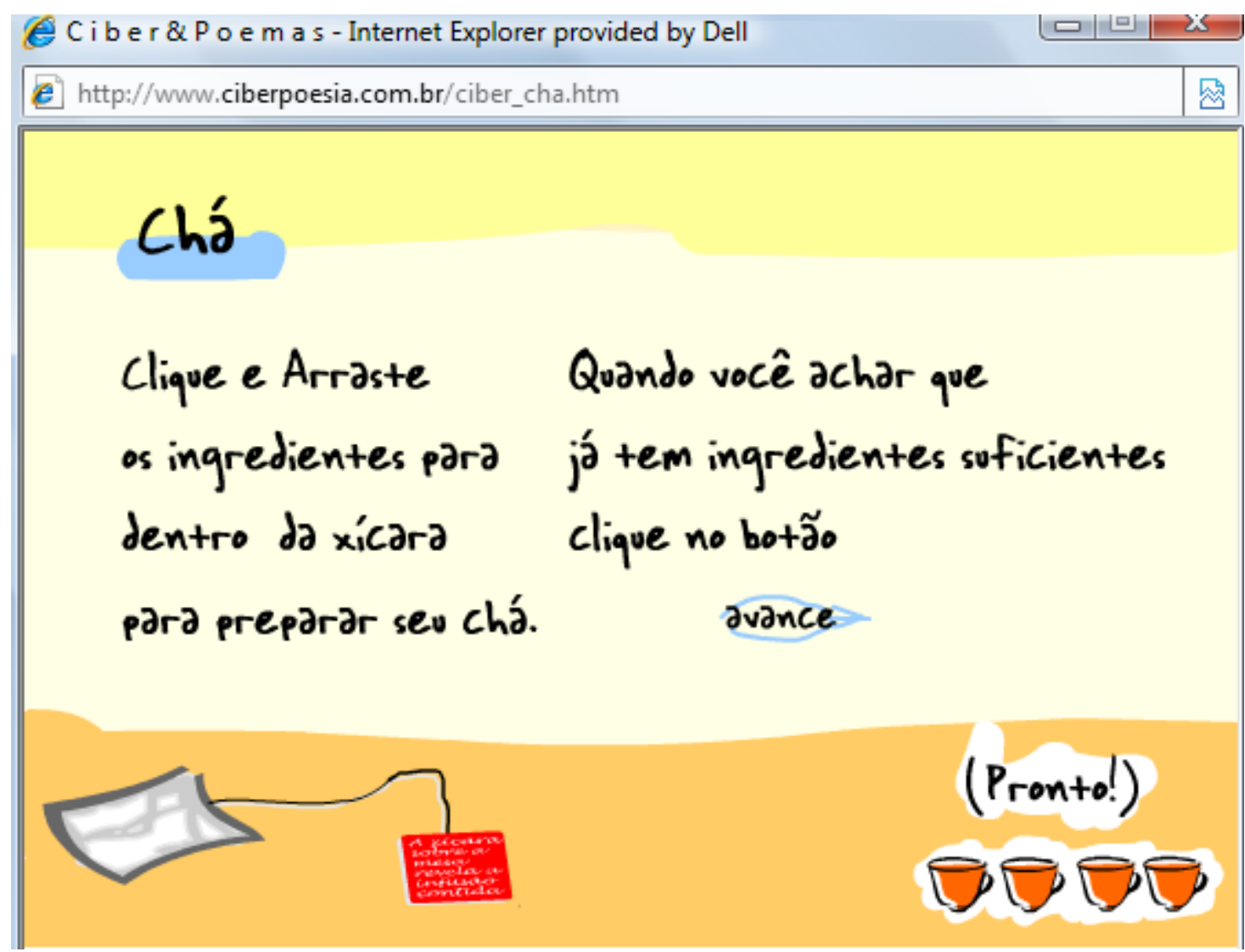

Cada passagem do mouse sobre um dos ingredientes é acompanhado de sons e imagens diferentes que fazem referência ao seu objeto, por exemplo, o som da foto do casal é de beijos, o tilintar da colher ao misturar dentro da xícara, etc.

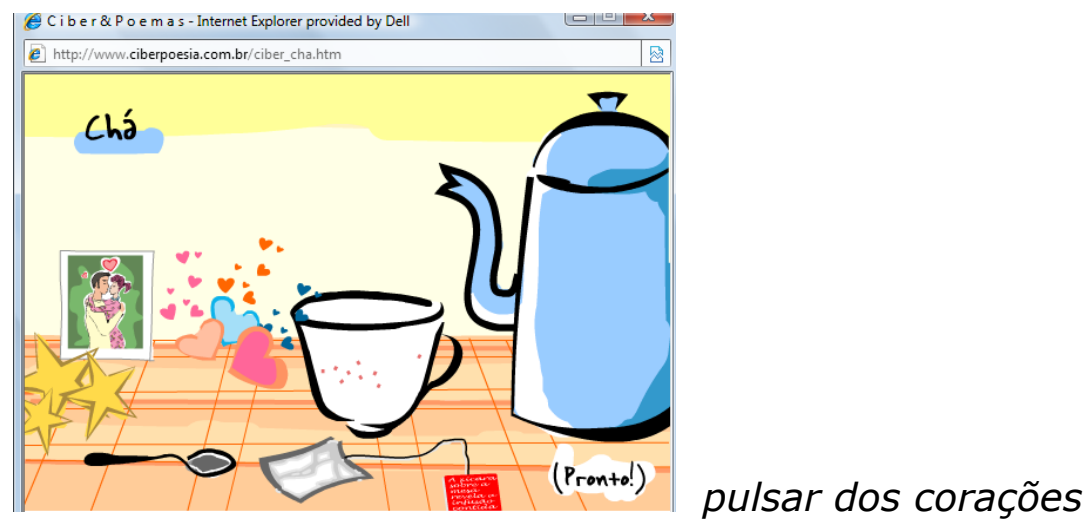




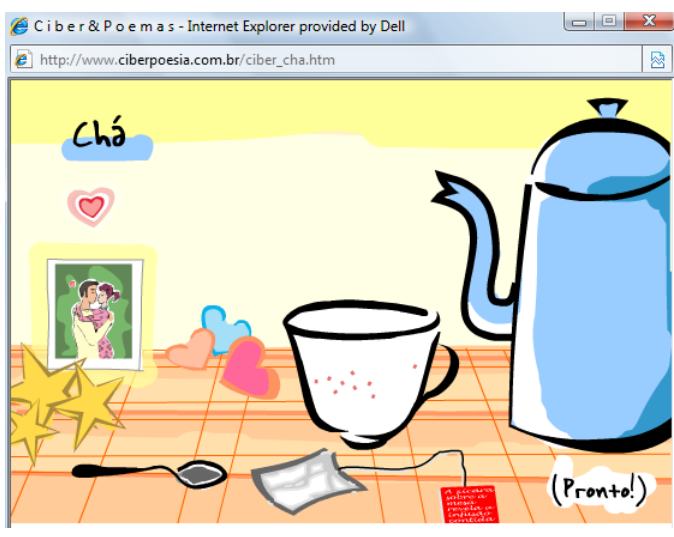

beijos do casal

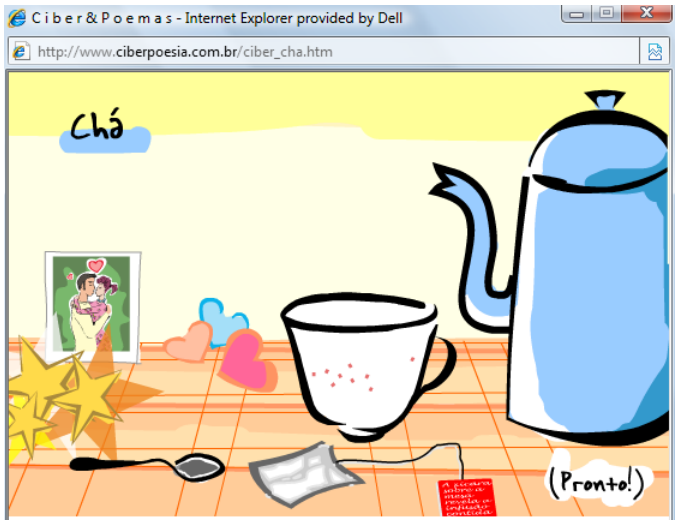

estralar das estrelas

Os ingredientes básicos são o saquinho de chá e a água, os outros são opcionais e determinam a apresentação final do poema, cujo texto verbal transcrevemos abaixo:

"Deixe a infusão

o tempo necessário

até que os nossos aromas

e os nossos sabores

se misturem". 


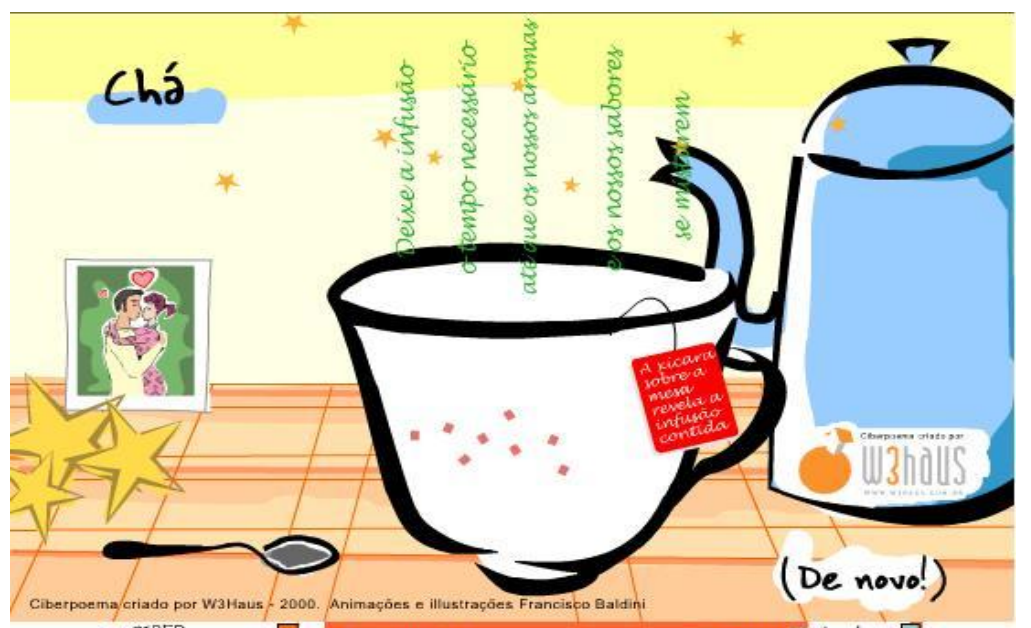

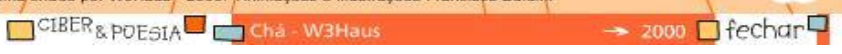

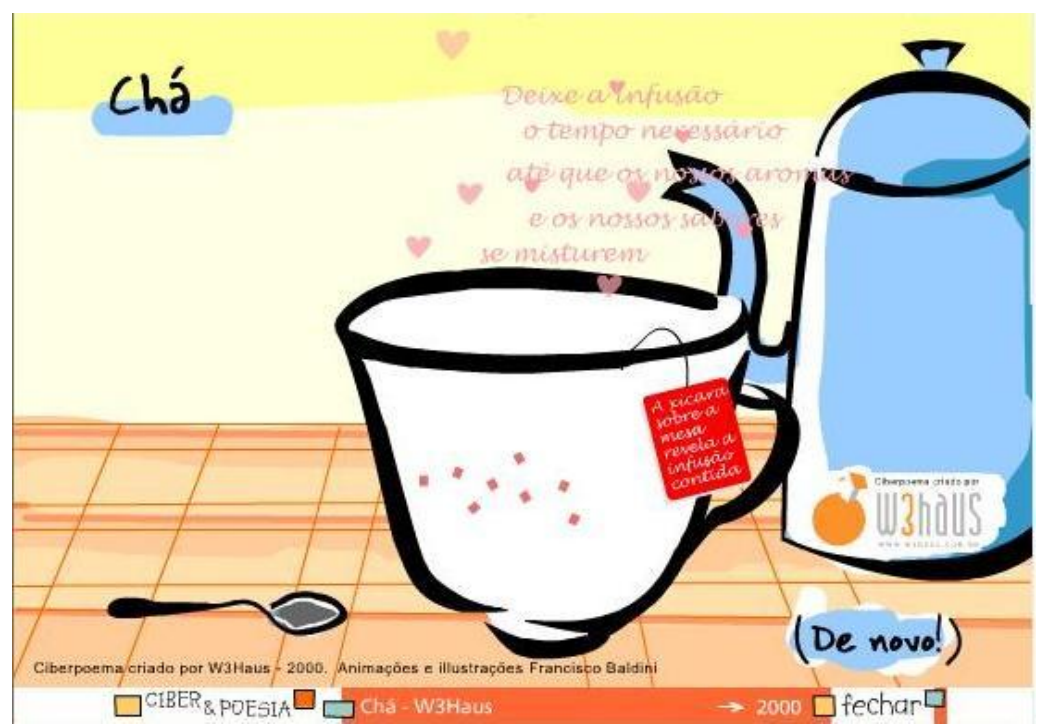

Interessante observar que a água colocada é o alfabeto de letras que se misturam ao saquinho de chá para formar os versos e na falta de um dos ingredientes principais o chá não fica pronto e, portanto, a obra não se realiza.

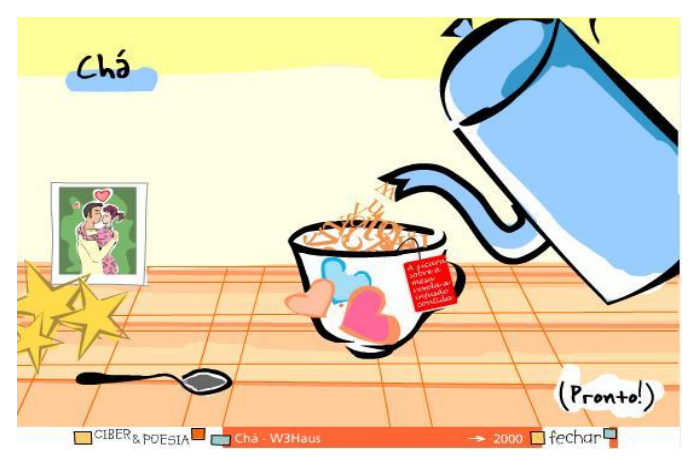



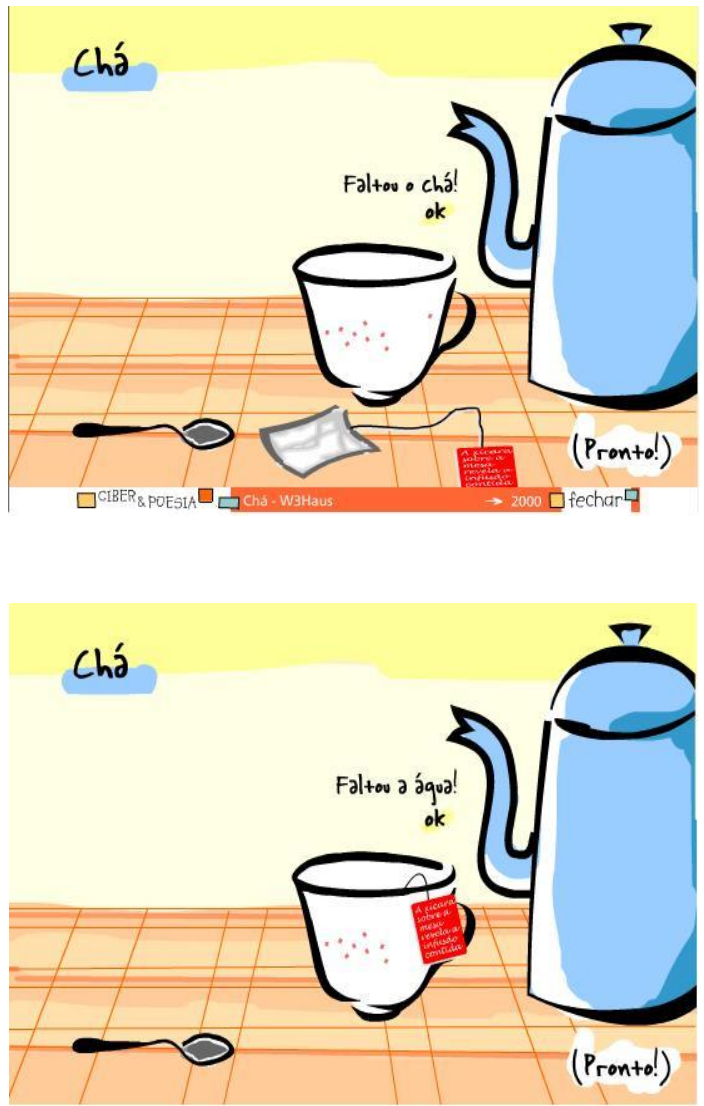

As escritas do saquinho de chá são quase imperceptíveis, mas com um olhar mais atento e o zoom (ferramenta utilíssima) conseguimos ler "A xícara sobre a mesa, revela a infusão contida".

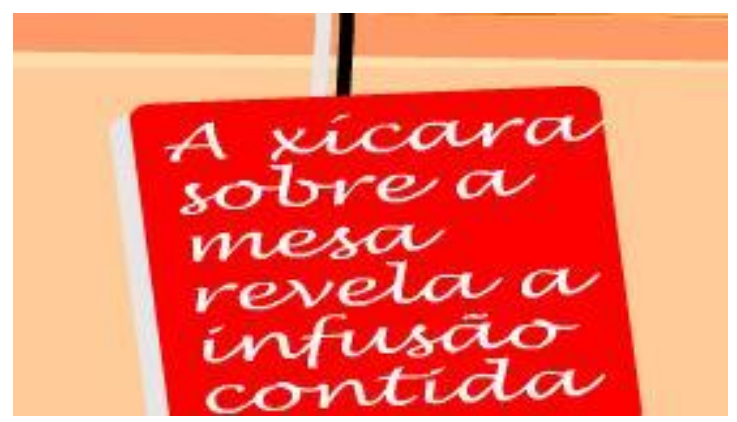

Ao final, ao som de aplausos, a xícara parece vir em nossa direção, como se estivesse nos convidando a experimentar o chá preparado. 

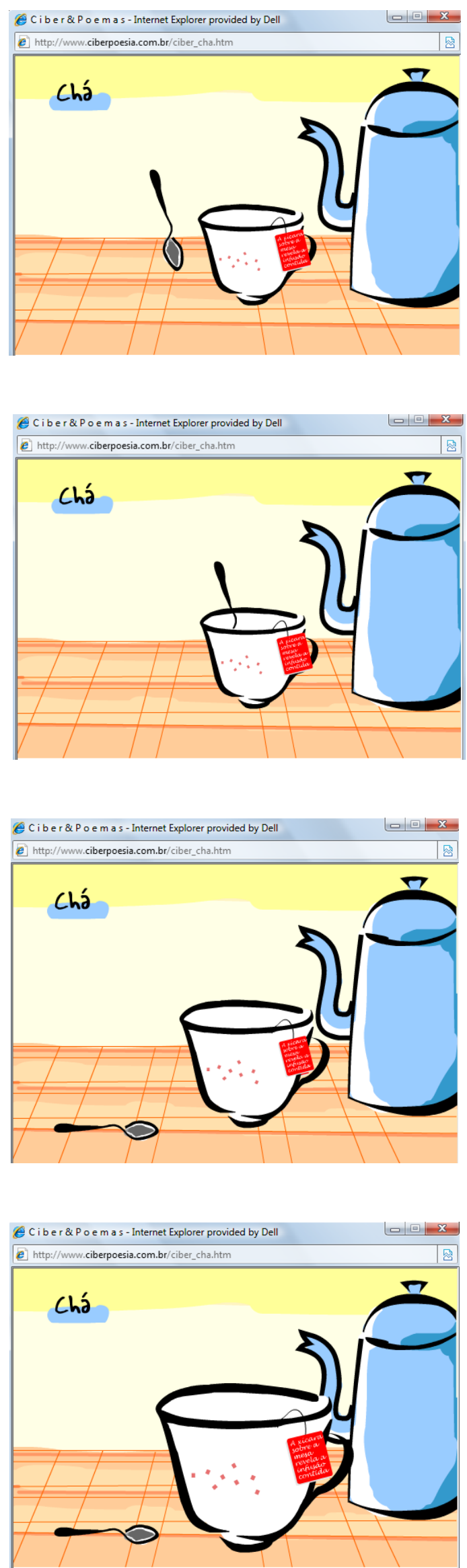


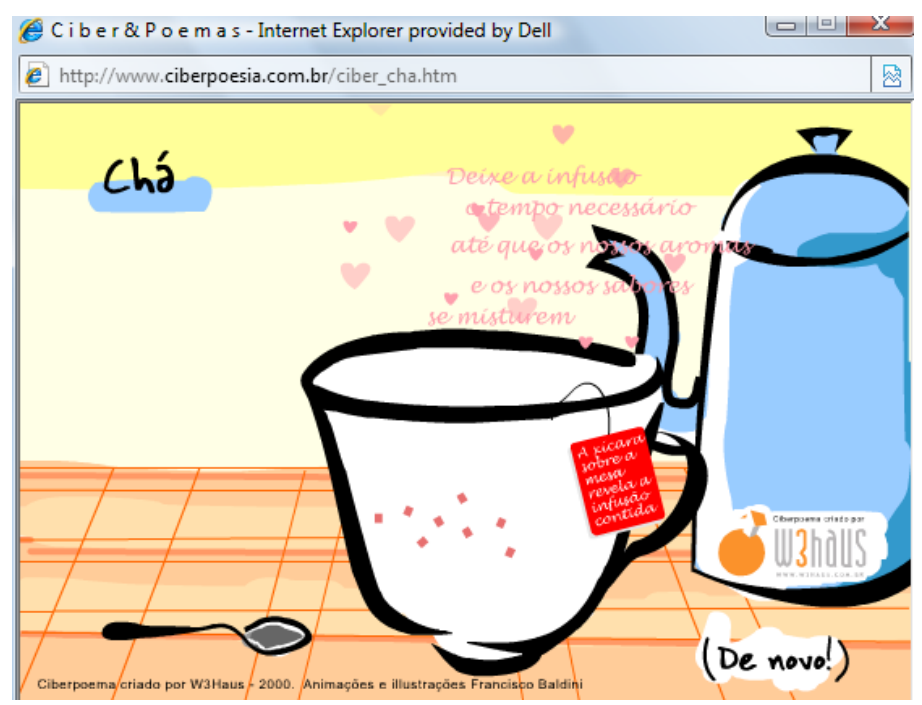

A escolha do ambiente, dos objetos e dos ingredientes remete-nos à singeleza da vida, que não vale a pena se não houver com quem compartilhar (a foto), o amor (corações) e os sonhos (estrelas). Para isso, não é necessário nada sofisticado, é na simplicidade das coisas que encontramos a felicidade: nada mais simples e íntimo do que a cozinha de nossas casas, com o bule e a xícara de sempre em cima da conhecida toalha de mesa xadrez.

É uma obra que, a princípio, o leitor virtual vai clicando a esmo e depois se encanta com as diferentes combinações e resultados, solicitando, assim, diversas leituras, diversas tentativas e acessos.

Trata-se de uma obra em que a imagem interativa é predominantemente indicial, embora haja traços icônicos.

É um signo de existência concreta e reflexo de uma dada realidade, o tipo de receptor pode ser classificado como 'ator' pois ele escolhe e decide como a obra deve acontecer.

Nota-se a virtualização do corpo e atualização do lugar quando o leitor escolhe os ingredientes, ele parece estar na cena preparando o chá. 
Mas, se considerarmos que a escolha dos ingredientes metafóricos (corações, estrelas, foto, água/letras) e real (chá) determinam a apresentação da estrutura final do poema, temos a virtualização poética e atualização do modelo.

A princípio, a obra parece ser apenas um passatempo, mas trata-se de um jogo poético, em que as combinações de som, imagem e escrita resultam diferentes apresentações, diferentes significações, as escolhas se dão de forma emocional resgatando sempre a "sensação de encantamento".

À medida que se reconhecem os elementos coesivos e constitutivos da imagem interativa, o leitor/navegador criará estratégias de leitura para a construção de sentidos (coerência) da obra e deixará de ser meramente um ser que, de forma passiva, aceita o que the vem aos olhos.

Entender que o leitor imersivo passa por estágios que engendram tentativas, hipóteses, raciocínio, controle, ações, ou em outros termos, níveis - errante, detetive, previdente - faz com que, nós educadores, possamos identificar e assim intervir no processo de aprendizagem significativa do educando. Pois para cada nível de leitor as ações deverão ser diferenciadas, a fim de proporcionar a apresentação gradativa dos elementos constitutivos da imagem interativa. Dessa forma, o leitor passa a questionar, a refletir sobre o que se lhe apresenta, seu olhar se redefine. A obra, então, deixa de ser apenas "passatempo" e torna-se arte.

A arte é sempre uma interrogação do olhar, um despertar e 
um colocar em questão percepções (visuais, auditivas, corporais e outras), uma instigação para explorar seus limites, para o único e intenso prazer de um gozar perceptivo. (COUCHOT; TRAMUS; BRET, 2003, p.38) ${ }^{32}$

${ }^{32}$ In: DOMINGUES, Diana (org.) Arte e vida no século XXI: tecnologia, ciência e criatividade. São Paulo: Editora UNESP, 2003. 


\section{Capítulo IV}

"O cultivo da ambiguidade e e espraiamento das neblinas de sentido é uma tarefa da poesia que nos traz maneiras de sentir e ver que, sem ela, seriam impossíveis". SANTAELLA, 2003, p.14

Neste capítulo, apresentamos dois projetos realizados em uma escola pública, os quais nos levaram a refletir acerca de situações que possibilitem vivenciar a poesia, a literatura, reflexões essas que nortearam o percurso deste trabalho.

\subsection{Vivências Poéticas}

A poesia, a literatura ou a arte em geral têm importante papel a cumprir: revelar novas formas de ver, sentir, apalpar, viver o mundo. 0 ser humano, adormecido pela apatia da vida rotineira - algo que o torna também insensível e desavisado em relação ao jogo do poder e do pensamento hegemônico - na vivência com o poético, pode acordar, pode transcender para um ser mais vivaz, crítico, solidário, ético. A leitura efetiva dos diversos textos que compõem a cultura, a sociedade, o universo, entre esses, a leitura dos textos que nos fazem vivenciar poeticamente algumas situações, possibilita 0 crescimento interior/individual e, consequentemente, dimensiona nossa práxis, nossa atuação na sociedade,

leva-nos à dimensão poética da existência humana. Revela que habitamos a Terra, não só prosaicamente - sujeitos à utilidade e à funcionalidade -, mas também poeticamente, destinados ao deslumbramento, ao amor, ao êxtase. Pelo poder da linguagem, a poesia nos põe em comunicação com 
o mistério, que está além do dizível. (MORIN, 2002a, p.45)

Para que a poesia e o texto literário cumpram seu papel, é necessário que a relação leitor-texto leve em consideração três aspectos: "sensoriais (ver, ouvir os símbolos lingüísticos), emocionais (identificar-se, concordar, discordar, apreciar) e racionais (analisar, criticar, correlacionar, interpretar)." (GÓES, 2003, p.17)

Ler uma obra artística impressa ou em espaço hipermidiático é algo que pode ser entendido como um processo complexo, por meio do qual tecem-se sonhos, constrói-se mundos e vontades. No entanto, temos de lembrar que não nascemos leitores de literatura, sequer nascemos leitores do mundo e de suas intrincadas relações sociais, precisamos ser educados para ler as obras, os livros e a vida.

A educação, na família, na escola, na vivência da vida, não é um processo natural; nós nos formamos leitores na medida em que formos instrumentalizados adequadamente para isso. Nossa relação com a obra literária necessita de estar em consonância com nossas relações pessoais, sociais, com a nossa época e com a trama de linguagem na qual nos engendramos e na qual nos inserimos.

As obras de Literatura Infantil e Juvenil, cada vez mais, se tecem no diálogo entre diferentes linguagens e diferentes suportes, exigindo para acionar aspectos como os citados por Góes; um olhar mais acurado para o perceber da qualidade estética e dos efeitos de sentido resultantes de uma leitura efetiva. A fruição plena de uma obra exige, inclusive, que o leitor reconheça recursos e meios utilizados pelo artista. 
O conhecimento da teoria semiótica da percepção pode favorecer a visão crítica do professor, suas análises e sua formação como leitor e mediador de leituras.

Baseados nessas prerrogativas, foram elaborados os projetos "Semeando Sonhos" e "Café com Poesia". Eles constituem uma possibilidade de a escola, no âmbito das ações educacionais, agenciar o papel formador da literatura e contribuir para resgatar o ser mais humano dentro de cada um, por meio de variadas expressões da arte. Nos dizeres de Coelho (1986, p.30):

a arte é na realidade, em suas diferentes manifestações, 0 fenômeno que descobre o mundo à Humanidade. [...] a Arte é uma espécie de ponte entre a realidade comum que nos rodeia e o mundo do indizível, que escapa à percepção comum, o mundo dos valores ocultos, onde pressentimos todas as respostas para as indagações essenciais que assaltam o homem, quando este toma consciência de ser um EU situado num universo incomensurável e incompreensível. A tarefa do artista-criador é revelar aos seus semelhantes as múltiplas faces da realidade comum que os rodeia, e os possíveis valores do mundo do indizível, que deverá dar o sentido derradeiro àquela realidade comum.

As obras aqui analisadas - "O Cântico dos cânticos", "Mandaliques" e "Chá" - e os projetos foram vias encontradas para despertar o "olhar de encantamento" de que vimos falando ao longo deste trabalho e, assim, valorizar e aproximar o texto literário, em suas diferentes expressões, e modos de produção de linguagem, presentes em nossa contemporaneidade, entre livros e telas (CUNHA, 2008): verbal, imagética e digital, formas que agenciam diferentes perfis de leitores.

Afinal, "é no leitor que o texto literário se completa ou encontra seu 
significado final." (COELHO, 2000, p.132)

Antes de apresentarmos os projetos, faremos uma breve contextualização da escola e dos alunos envolvidos. Enfatizamos que a realização deste processo é apenas um dos caminhos possíveis de descoberta, por parte de jovens leitores, da poesia, da literatura, da arte, um contributo para a descoberta do outro e de si próprio, para a formação de seres mais plenos, sensíveis, reflexivos e humanos.

\subsection{A escola}

Os projetos de que trataremos a seguir ocorreram na Escola Municipal de Ensino Fundamental "Madre Maria Imilda do Santíssimo Sacramento", localizada em Vila Curuçá, próximo ao Itaim Paulista, periferia da zona leste e pertencente à Diretoria Regional de Educação de São Miguel Paulista.

A escola foi criada pelo Decreto $n^{\circ} 3.895$ de 02 de junho de 1958 e inaugurada em 27 de setembro de 1959. Dada sua longa história junto à comunidade local, esta a tem em grande estima.

A comunidade escolar é composta por muitas famílias migrantes da região Norte e Nordeste do país. Muitas avós e avôs tomam conta dos netos e acabam respondendo por eles quando solicitada a presença dos responsáveis, que ou trabalham ou são separados e deixaram os filhos a cargo dos avôs.

A zona leste de São Paulo apresenta grande déficit de serviços básicos tais como os de saneamento, assistência médica e hospitalar, 
educacionais, de cultura e lazer. Essas insuficiências se agravam com o desemprego crescente e com índices de violência alarmantes.

Atualmente a escola possui 14 salas de aula, 01 laboratório de informática, 01 sala de leitura, 01 sala de vídeo, 01 sala de coordenação, 01 sala da direção, 01 sala dos professores, 01 secretaria e 02 quadras externas. Funciona em três períodos diurnos: das 06:50 às 10:50, das $10: 55$ às $14: 55$ e das $15: 00$ às $19: 00$. Atendendo por volta de 1.500 alunos do ciclo I ( $1^{\mathrm{a}}$ a $4^{\mathrm{a}}$ séries) e do ciclo II ( $5^{\mathrm{a}}$ a $8^{\mathrm{a}}$ séries).

\subsection{Os alunos}

Os projetos foram aplicados no ano de $2006 / 2007$ em cinco turmas pertencentes ao $3^{\circ}$ período, $2^{\circ}$ ano do Ciclo II nas quais lecionei.

Em cada turma havia por volta de 35 alunos matriculados, com histórias e circunstâncias de vida diversas.

Naquele ano, os alunos utilizaram o Laboratório de informática uma vez por semana, mas não foi possível o acesso à Sala de Leitura por não haver professor designado, fato que ocasionou várias reflexões referentes à necessidade de leitura diversificada nas aulas.

Por se tratar da periferia de São Paulo, muitos vivem e convivem com situações de violência e descaso, por vezes, até por parte da própria família. Diante disso, a rebeldia, o enfrentamento eram formas, a meu ver, de carência de atenção, de carinho e de limites. Sensibilizá-los por meio da Literatura Infantil e Juvenil, sobretudo da poesia, entendíamos necessário e urgente para tentar resgatar o ser humano, sensível, 
solidário e ético dentro deles.

Para entendermos um pouco melhor de nosso público-alvo, fizemos uma pesquisa sobre a importância da leitura para eles. As questões, a tabulação dos resultados e algumas considerações a respeito encontramse anexo.

\subsection{Projeto "Semeando Sonhos"}

$$
\begin{array}{r}
\text { "A função primeira do livro infantil é a estético-formativa, a educação da sensibilidade, } \\
\text { pois reíne a beleza da palavra e a beleza das imagens. O essencial é a qualidade de } \\
\text { emoção e sua ligação verdadeira com a criança." } \\
\text { Lucia Pimentel } \mathcal{S}_{\text {óes }}
\end{array}
$$

O projeto "Semeando sonhos" nasceu das reflexões sobre leitura entre mim e o professor de História, Pedro Olavo dos Santos. Sentíamos a necessidade de mudar algo para aproximarmos o aluno de leituras diversificadas e livres.

A escolha do nome deste projeto "Semeando Sonhos" se deu pelo próprio sentido da palavra semear.

Semear- 1. Deitar ou espalhar sementes de, para que germinem. 2. Espalhar ou deitar sementes em. 3. Espalhar, propalar, publicar. 4. Produzir, causar, ocasionar. 5. estimular, promover, fomentar. 6. Colocar aqui e ali, sem ordem.

Lançar sementes de leitura, para que germinem e promovam em nossos jovens, o hábito de ler, criticar e sentir. Hábito não é obrigação, é algo natural que surge por meio da necessidade ou por estímulo de outro.

No ato da leitura, o indivíduo passa a viver, a sentir as experiências 
das diversas possibilidades humanas e nesse processo, acreditamos que "a arte capacita o homem para compreender a realidade e o ajuda não só a suportá-la como a transformá-la, aumentando-lhe a determinação de torná-la mais humana e mais hospitaleira para a humanidade". (FISCHER, 1971, p.57)

Para viabilizar o projeto recorremos a uma "bolsa" com vários títulos de livros e gibis para que cada aluno escolhesse a leitura a ser feita. A escolha dos títulos foi criteriosa e atenta, pois sabemos que o nível de leitura numa sala de aula não era o mesmo, então, procuramos escolher livros que pudessem contemplar a todos.

Cada um confeccionou uma ficha individual na qual registraram data, leitura feita e comentários. Foi dedicada uma aula por semana e no ato da leitura houve música ambiente (MPB, Clássica ou Instrumental).

A música ambiente, inicialmente, gerou alguns protestos, pois, adolescentes que são, queriam ouvir as músicas da moda (funk, rap), mas explicando a eles que nossa proposta era que eles conhecessem outra cultura, outras modalidades, que talvez não tivessem oportunidade fora da escola, acabaram aceitando e alguns até gostando muito.

Foi idealizado dessa forma para que esse momento de leitura fosse agradável, compartilhado com colegas e professor e não como algo obrigatório. Desejamos que a leitura se tornasse uma aliada, um suporte para os alunos, não uma inimiga a ser combatida.

Neste projeto apresentamos aos alunos as três obras analisadas neste trabalho: Mandaliques, de Tatiana Belinky, Cântico dos Cânticos, de 
Ângela Lago e Chá, de Sergio Capparelli e Ana Claudia Gruszynski.

A primeira obra foi uma diversão. O humor cativante os envolveu de tal forma que ao sugerir que eles próprios fizessem seus limeriques, de pronto aceitaram e a produção não poderia ter sido melhor. Vejam:

"Eu conheço um menino muito chato. Um dia estava passeando e cai no asfalto. Ele olhou e disse:_Bem feito! Olhei pra ele e disse com todo respeito: _ Ah! Vai procurar macaco de calcinha e salto alto!"

"Professora linda do meu coração Não passe mais lição.

Que eu te dou um presente E a senhora irá ficar contente. E a senhora ainda me dará um abração".

Já a segunda obra "Cântico dos Cânticos", inicialmente, causou estranheza, pois "Ler o quê? Só tem desenho." Pedindo atenção deles às imagens, começamos a folhear o livro, alguns reclamaram de "uma certa vertigem", outros admiraram a beleza das formas. Ao mostrar a eles que o livro é interminável, começo e fim indefinidos, tentou-se buscar uma narrativa. A busca sem fim do amor ou os encontros e desencontros do amor.

Foi importante eles perceberem que as imagens abrem várias possibilidades de leitura, elas também querem dizer e significar algo para alguém. Foi um exercício de ampliação do olhar, afinal

A leitura não-verbal é uma maneira peculiar de ler: visão/ leitura, espécie de olhar tátil, multissensível, sinestésico. Não se ensina como ler o não-verbal. É mais um 
desempenho do que competência porque, sendo dinâmico, o não-verbal exige uma leitura, se não desorganizada, pelo menos sem ordem preestabelecida, convencional ou sistematizada. (FERRARA, 1986, p.26)

A terceira obra "Chá" foi uma surpresa para os alunos, já que o uso do computador servia para eles como fonte de pesquisa, envio de e-mails ou jogos. Ter uma poesia em meio midiático impressionou-os muito, a livre escolha dos ingredientes, os sons, os movimentos, tudo parecia ser novidade, não o suporte em si (computador), mas a forma como pode ser utilizada para mostrar um resultado poético. O "olhar de encantamento" se deu ao "deslocar a ênfase do objeto (o computador, o programa, este ou aquele módulo técnico) para o projeto (o ambiente cognitivo, a rede de relações humanas que se quer instituir)" (LÉVY, 1993, p.54)

Acreditamos que com a apresentação e o contato com essas três obras diferentes, pudemos iniciar o processo de re-encantamento do olhar: perceber possibilidades diversas onde não se esperava. A transcendência do ser através da literatura, pois como diz Lajolo (2001b, p.44):

A literatura é porta para variados mundos que nascem das várias leituras que dela se fazem. Os mundos que ela cria não se desfazem na última página do livro, na última frase da canção, na última fala da representação nem na última tela do hipertexto. Permanecem no leitor, incorporados como vivência, marcos da história de leitura de cada um. Tudo o que lemos nos marca. 


\subsection{Projeto "Café com Poesia"}

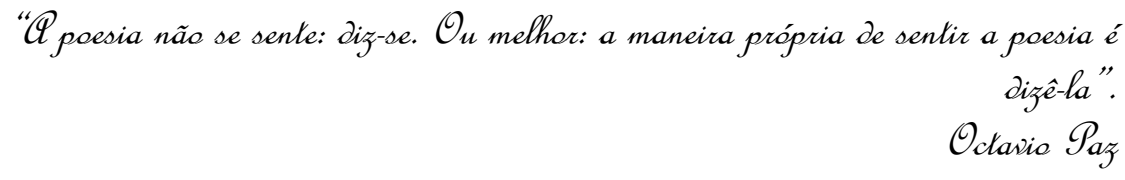

"Café com poesia" foi um projeto realizado para complementar o primeiro "Semeando Sonhos", enquanto este visava germinar sementes de leitura, aquele endereçava-se para efetivar processos de absorção, compreensão e produção de leituras feitas; a apresentação do resultado em espaço compartilhado faz com que haja o reconhecimento e a valorização, fatores essenciais na formação do ser humano, uma vez que mobilizam três aspectos fundamentais: o respeito, a colaboração e a solidariedade.

Cada bimestre foi dedicado a dois poetas brasileiros, vida e obra foram pesquisadas em livros e no Laboratório de Informática. A escolha dos autores ocorreu por meio de discussões quanto à disponibilidade e acessibilidade do material na escola, adequação da temática e elaboração lingüística aos jovens. Assim definiu-se: Tatiana Belinky e Sergio Capparelli ( $1^{\circ}$ bimestre), Carlos Drummond de Andrade e Vinícius de Moraes ( $2^{\circ}$ bimestre) , Cecília Meireles e Cora Coralina ( $3^{\circ}$ bimestre) e Adélia Prado e Thiago de Melo ( $4^{\circ}$ bimestre).

Foi proposto um cronograma, e os alunos em data marcada apresentaram os poemas de que mais gostaram ou que eles próprios construíram a partir das leituras realizadas, mostrando seu poder de intervenção e criação. A forma de apresentação mostrou como eles 
sentiam e entendiam os textos, deixando entrever processos internos que a leitura provocava. A declamação de um poema resgata a dimensão semiótica da voz, entonação, timbre, enfim, do ritmo, da música, da sonoridade tão próprios do universo poético.

Foram propostas diversas e diferentes apresentações musicais e teatrais pelos próprios alunos, nas quais os jovens revelavam competência de leitura e habilidades de compreensão, interpretação e recriação de textos lidos.

Este projeto possibilitou aos jovens vivenciar situações de colaboração para organizar o evento, de respeito para com o colega que se apresentava e de solidariedade com o nervosismo, com os pequenos deslizes que por vezes ocorreram, fazendo-os experienciar elementos básicos da formação do ser ético.

Leitura, experiência estética, pensamento e conduta ética demandam processos que são aprendidos e apreendidos com maior efetividade em situações de vivência e convivência que oportunizem tais práticas.

Uma pequena mostra deste projeto está registrada em fotos anexas a este trabalho.

\subsection{Avaliação dos projetos}

Trabalhar com os dois projetos: "Semeando Sonhos" e "Café com Poesia" levou-nos a buscar critérios de escolhas de leituras para os jovens, a buscar mediações mais competentes e mostrou-nos que ainda é 
possível sensibilizar nossos jovens e adolescentes, fazendo, inclusive, com que eles cultivem o respeito, a solidariedade, o amor ao próximo. Para os nossos propósitos, a Literatura Infantil e Juvenil teve um papel importante.

Em "Semeando Sonhos" nosso intento foi de estimular a curiosidade, a criatividade, a criticidade através da leitura.

Kleiman (2001, p.153) diz:

A leitura silenciosa $[\ldots]$ permite à criança envolver-se totalmente na busca de significados utilizando para isto seu próprio ritmo de leitura e as regressões ou releituras que se Ihe fizerem necessárias.

Nesse aspecto, respeitar o ritmo e o gosto de cada um, fez com que todos participassem ativamente do processo, já que, parafraseando Manguel (1997,p.68), permitiu "a comunicação sem testemunhas entre o livro e o leitor". Foi um encontro aberto e franco, uns com mais dificuldade, outros com menos, mas, o mais importante, sem cobrança (a princípio) e a exigência de que todos tivessem as mesmas habilidades de leitura.

A princípio, o processo se desenvolveu individualmente, pouco a pouco, alguns preferiram ler em grupos, tornando-se uma diversão, uma troca com o outro, enquanto um lia os outros prestavam atenção. Assim desenvolveram-se momentos muito profícuos de leitura compartilhada.

"Café com Poesia" foi uma forma de fazer com que os alunos tivessem contato com diferentes poetas e linguagens. Ao declamar um poema, o aluno se fazia presente, se reconhecendo como um ser 
transformador e sendo reconhecido como tal pelos outros. Portanto, mesmo aquele que antes passava despercebido ou era reconhecido somente por fatos negativos, nesse contexto, era aplaudido por fazer Arte em suas diversas modalidades: declamação, teatro ou música.

Ambos os projetos se pautaram na prerrogativa de que a Literatura Infantil e Juvenil tem um papel a cumprir, como diz Góes (1984, p.24):

Educar é preparar para a vida, portanto é importante ajudar o jovem a obter maior clareza de mente e enriquecimento da sensibilidade. Além desse aspecto essencial, o desenvolvimento da leitura entre as crianças resultará em um enriquecimento progressivo no campo dos valores morais, no campo racional, no da cultura e da linguagem.

Cabe às instituições e aos educadores proporcionar tal ambiente de contato e aprendizagem para o mundo. Ao final dos projetos, a avaliação dos alunos foi realizada com muito entusiasmo. Segundo eles, foi uma forma diferenciada de trabalho e de estudo. Tudo que não é rotineiro fisga a atenção, envolve e incentiva o jovem e a criança a participar ativamente, foi o que aconteceu em todos os processos: seja o de leitura ou de apresentação. Dessa forma, a cada investida, o ser se enriquece tanto intelectual quanto sensivelmente, além de aproximar as relações humanas: entre colegas e entre professor-aluno. 


\section{Considerações finais}

Neste trabalho, traçamos um percurso reflexivo sobre a formação do ser e as formas de linguagens (em hibridização) presentes neste terceiro milênio em que temos observado a supervalorização do Ter e o esquecimento do Ser.

Coelho (1986,p.204) coloca que:

A exageração do ideal do Ter acaba impedindo a realização do homem no plano individual (interior, íntimo, essencial), pois este necessita de outros valores que o alimentem. Os valores puramente materiais, embora decisivos, não bastam. O homem é um ser dual: ser individual e social. Esse fenômeno tão óbvio e elementar frequentemente é esquecido pelas idéias dirigentes, com muitas conseqüências perniciosas para a harmonia dos seres. Se essas duas faces de sua personalidade não tiverem oportunidade de se realizar com liberdade e em harmonia uma com a outra ele entra em crise.

Diante de um olhar apático sobre a vida e de uma rotina massacrante, consumista, o ser tem poder de transcendência, pois não cessa nunca de aprender e desenvolver.

Toda aprendizagem será significativa quando se ativa o "olhar de encantamento", pois é através dele que a curiosidade, a criatividade e a criticidade são acionadas de tal forma que cada leitura passa a exigir do leitor saberes diversos que se agreguem e se articulem ao do código escrito.

Em nosso percurso vislumbramos afinal uma forma de interrogar o texto literário na sua interação com outros textos, isto é, com a contemporaneidade, suas revoluções e os textos culturais como a 
violência, a apatia, o desencantamento que se instauram interceptando o projeto humano do homem.

Se a literatura, em especial, a poesia tem papel social a cumprir, esse papel é o de fazer com que o ser desperte para outras possibilidades de ação frente à complexidade do mundo em que vivemos e do ser humano que somos. Dessa forma, podemos tecer relações (ora solitárias, no âmbito individual; ora solidárias, no âmbito coletivo) fecundas entre leitura, que oportuniza o crescimento e o amadurecimento interior, e o mundo social, a alteridade.

Por uma sociedade mais justa, mais solidária e menos egoísta, urge conscientizar e tocar a alma e o coração de nossos jovens e crianças através de múltiplos meios de produção de linguagem, da palavra e do livro.

"Livros não mudam o mundo, quem muda o mundo são as pessoas. Os livros só mudam as pessoas". Mário Quintana 


\section{Bibliografia}

ABDALA Jr., Benjamin. Literatura, História e Política literaturas de lingual portuguesa no século XX. São Paulo: Ática, 1989.

.(org.) Margens da cultura: mestiçagem, hibridismo \& outras misturas. São Paulo: Boitempo, 2004.

BAITELLO Jr., Norval. O animal que parou os relógios. São Paulo: Annablume, 1997.

BAKHTIN, Mikhail. Estética da criação verbal. São Paulo: Livraria Martins Fontes, 1992.

BARROS, Manoel. Menino do mato.São Paulo: Texto editores, 2010.

BELINKY, Tatiana. Mandaliques (com endereço e tudo). São Paulo: Ed. 34, 2001.

BENJAMIN, Walter. Magia e técnica, arte e política: ensaios sobre literatura e história da cultura. Trad. Sérgio Paulo Rouanet. 7a Ed. São Paulo: Brasiliense, 1994.

. Reflexões: A criança, o brinquedo, a educação. São Paulo: Summus, 1984.

BOSI, Alfredo. Reflexões sobre a arte. São Paulo: Ática, 2001. O ser e o tempo da poesia. 6aed. São Paulo: Cia das Letras, 2000.

. (org.) Cultura Brasileira - temas e situações. $4^{\mathrm{a} e d .}$ São Paulo: Ática, 1999. 
CANDIDO, Antonio. Vários Escritos. $4^{\mathrm{a} e d .}$ São Paulo: Duas Cidades, 2004.

. Textos de intervenção. São Paulo: Ed.34, 2002.

. O estudo analítico do poema. São Paulo: Humanitas Publicações/ FFLCH/USP, 1996.

. Literatura e sociedade. 7aed. São Paulo: Ed. Nacional, 1985.

Cântico dos cânticos. Traduzido do grego por Antonio Medina Rodrigues. São Paulo: Labortexto Editorial, 2000.

CARVALHAL, TANIA. Literatura Comparada. $4^{\mathrm{a} e d .}$ São Paulo:1999.

CAVAlLO, G. e CHARTIER, R.(org.) História da Leitura no Mundo Ocidental 2. São Paulo: Ática, 2002.

CHALHUB, Samira. A metalinguagem. São Paulo: Ática, 1986. . Funções da linguagem. São Paulo: Ática, 1987.

CHARTIER, Roger. A aventura do livro - do leitor ao navegador. Trad. Reginaldo de Moraes. São Paulo: Editora UNESP/ Imprensa Oficial do Estado de São Paulo, 1999.

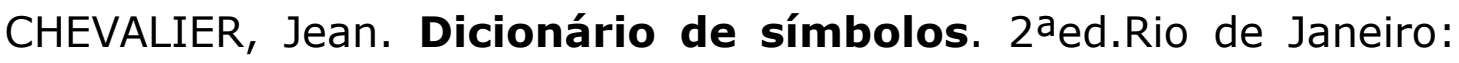
José Olympio,1989.

COELHO, Nelly Novaes. "Literatura e homem sem transcendência" in: Escolas Literárias no Brasil. Coord.de Ivan Junqueira. Rio de Janeiro: Academia Brasileira de Letras, 2004.

- Literatura: arte, conhecimento e vida. São Paulo: 
Peirópolis, 2000.

. "Leitura literária versus leitura de mundo" in:Revista

LEAD, São Paulo, ano III, nº16, 1991.

A literatura infantil: história, teoria, análise $4^{a}$ ed. São

Paulo: Quíron, 1987.

. "A poesia como ato de busca" in: O Estado de São Paulo,

Cultura, São Paulo, 21 mar.1987.

. Literatura e Linguagem: a obra literária e a expressão lingüística. 4ª Ed. Reformulada, São Paulo: Quíron, 1986.

COUCHOT, Edmond. A tecnologia na arte - da fotografia à realidade virtual. Porto Alegre: Ed. UFRGS, 2003.

COUTINHO, E.F. e CARVALHAL, T.(org.) Literatura Comparada textos fundadores. Rio de Janeiro: Rocco, 1994.

CUNHA, Maria Zilda da. Na tessitura dos signos contemporâneos. São Paulo: Paulinas, 2009.

DOMINGUES, Diana (org.) Arte e vida no século XXI: tecnologia, ciência e criatividade. São Paulo: Editora UNESP, 2003.

DONDIS, Donis A. Sintaxe da linguagem visual. São Paulo: Martins Fontes, 1991.

DURAND, Gilbert. O imaginário: ensaio acerca das ciências e da filosofia da imagem. Trad. Renée Eve Levié. $3^{a}$ ed. Rio de Janeiro: DIFEL, 2004.

As estruturas antropológicas do imaginário: introdução à arquetipologia geral. Trad. Hélder Godinho. 2aed. São 
Paulo: Martins Fontes, 2001.

ELIADE, Mircea. Imagens e símbolos. São Paulo: Martins Fontes, 1991.

FARIA, Ernesto. Dicionário Escolar Latino-Português. 6a ed. Rio de Janeiro: FAE, 1994.

FELDMAN-BIANCO, Bela e LEITE, Miriam L.Moreira (orgs.) Desafios da imagem: fotografia, iconografia e vídeo nas ciências sociais.Campinas, SP:Papirus, 1998.

FERREIRA, Aurélio Buarque de Holanda. Dicionário Aurélio Básico da Língua Portuguesa. São Paulo, Nova Fronteira, 1995.

FERRARA, Lucrécia D'Aléssio. Leitura sem palavras. São Paulo: Ática, 1986.

FISCHER, Ernst. A necessidade da arte. Trad. Leandro Konder, 3aedição, Rio de Janeiro: Zahar Editores, 1971.

GARDIN, Carlos e OLIVEIRA, Maria Rosa Duarte. "Semiótica e Educação". In: Cadernos PUC - Arte \&Linguagem. No 14, s/d.

GOES, Lucia Pimentel. Olhar de descoberta - Proposta analítica de livros que concentram várias linguagens. São Paulo: Paulinas, 2003. . Introdução à literatura infantil e juvenil. São Paulo: Livraria Pioneira Ed., 1984.

HELD, Jaqueline. O imaginário no poder - as crianças e a literatura fantástica. São Paulo: Summus, 1980.

HUIZINGA, Johan. Homo ludens. São Paulo: Perspectivas, 2004. JAUSS, Hans Robert et al. A literatura e o leitor - textos de 
estética da recepção. Coordenação e tradução Luiz Costa Lima. São Paulo: Paz e Terra, 2001.

KLEIMAN, Ângela. Leitura: ensino e pesquisa. $2^{a}$ ed. Campinas: Pontes, 2001.

Texto e Leitor. Campinas, São Paulo: Pontes, 1989.

LA TAILLE, Y.;KOHL,M. e DANTAS, H. Piaget, Vygotsky, Wallon: teorias psicogenéticas em discussão. São Paulo: Summus, 1992

LAGO, Angela. O cântico dos cânticos. $3^{a}$ ed. São Paulo: Paulinas, 2005.

LAGO, Angela. O Cântico dos Cânticos: uma leitura através das imagens. PUC-PREPES. Belo Horizonte, 16 de julho de 1992.

LAJOLO, Marisa e ZILBERMAN, Regina. A formação da leitura no Brasil. São Paulo: Ática, 1996.

. Literatura infantil brasileira - História e histórias. $4^{a}$ ed. São Paulo: Ática, 1988.

LAJOLO, Marisa. Do mundo da leitura para a leitura do mundo. 6a ed. São Paulo: Ática, 2001a.

. Literatura: leitores e leitura. São Paulo: Moderna, 2001b.

LAPLANTINE, François. O que é imaginário. São Paulo: Brasiliense, 2003.

LEÃO, Lucia. O labirinto da hipermídia. São Paulo: Iluminuras, 2005.

O chip e o caleidoscópio - reflexões sobre as novas 
mídias. São Paulo: Editora Senac, 2005.

LÉVY, Pierre. O que é o virtual? São Paulo: Editora 34, 1996.

As tecnologias da inteligência: o futuro do pensamento na era da informática. Rio de Janeiro: Editora 34, 1993.

LIMA, Luiz Costa. A literatura e o leitor - textos de estética da recepção. Rio de Janeiro: Paz e Terra, 1979.

MANGUEL, Alberto. Uma história da leitura. São Paulo: Cia das Letras, 1997.

MARTINS, Maria Helena. O que é leitura? $3^{a}$ ed. São Paulo: Brasiliense, 1984.

MELLO, Ana Maria Lisboa. Poesia e imaginário. Porto Alegre: ED. PUC-RS, 2002.

MESQUITA, Armindo (Coord.) Pedagogias do imaginário Olhares sobre a literatura infantil. Lisboa: Edições ASA, 2002.

MORAIS, José. A arte de ler. São Paulo: Ed.Universidade Paulista, 1996.

MORIN, Edgar. Amor, Poesia, Sabedoria. 7aed. Rio de Janeiro: Bertrand Brasil, 2005.

A cabeça bem-feita: repensar a reforma, reformar o pensamento. $7^{\mathrm{a} e d .}$ Rio de Janeiro: Bertrand Brasil, 2002a.

A religação dos saberes - o desafio do século XXI. $3^{a}$ ed. Rio de Janeiro: Bertrand Brasil, 2002b.

Articuler lês savoirs - l'enseigment de La poesie. (proposta de organização de Jornadas Temáticas) Paris, janeiro/1998. 
. Introdução ao pensamento complexo. Lisboa: Instituto

Piaget, 1991.

. O problema epistemológico da complexidade. Lisboa:

Publicações Europa-América,1984.

. O paradigma perdido: a natureza humana. Portugal: Publicações Europa América, 1973.

PAZ, Octavio. O arco e a lira. Rio de Janeiro: Nova Fronteira, 1982. Signos em rotação. São Paulo:Perspectivas, 1972.

PEIRCE, Charles S. Collected papers. Cambridge, Massachusetes, The Belknap Press of Havard University Press, 1966, v.7

PIGNATARI, Decio. Comunicação Poética. 2a Ed., São Paulo: Cortez, 1978.

PLAZA, Julio. Arte e interatividade:autor-obra-recepção. In: ARS, ano 1, n०2, 2003.

PLAZA, Julio e TAVARES, Monica. Processos criativos com os meios eletrônicos: Poéticas digitais. São Paulo: Hucitec, 1998.

POUND, Ezra. A arte da poesia. São Paulo: Cultrix, 1976.

PROPP, Vladimir. Comicidade e riso.trad.Aurora Fornoni Bernardini e Homero Freitas de Andrade. São Paulo: Ática, 1992.

PROUST, Marcel. Sobre a leitura. 2a ed. São Paulo:Pontes, 1991. ROVERI, Sérgio. Tatiana Belinky... e quem quiser que conte outra. São Paulo: Imprensa Oficial, 2007.

ROSA, João Guimarães. Grande sertão: Veredas. $3^{a} e d . R i o ~ d e$ Janeiro:Editora José Olympio, 1963. 
SAID, Edwar W. Humanismo e crítica democrática. Trad.Rosaura Eickenberg. São Paulo: Companhia das letras, 2007.

. Representações do intelectual. Trad. Milton Hatoum. São Paulo: Companhia das Letras, 2005.

SALLES, Cecilia Almeida. Gesto inacabado: Processo de criação artística. São Paulo: FAPESP:Annablume, 1998.

SANTAELLA, Lucia e NOTH, Winfried. Imagem: cognição, semiótica e mídia. São Paulo: Iluminuras, 1999.

SANTAELLA, Lucia. Navegar no ciberespaço: o perfil cognitivo do leitor imersivo. São Paulo: Paulus, 2007.

. Culturas e artes do pós-humano: da cultura das mídias à cibercultura. São Paulo: Paulus, 2003.

A percepção: uma teoria semiótica. São Paulo: Experimento, 1993.

A assinatura das coisas - Peirce e a literatura. Rio de Janeiro: Imago, 1992.

. Como chegar até a semiótica de Peirce. O Estado de São Paulo, São Paulo,08/10/1983, Caderno de Programas e Leituras. . Lendo o problema da leitura.Cadernos PUC,São Paulo, no.08,p.03-10

SANTOS, Laymert. O homem e a máquina. Revista Imagens, Campinas, n03, dez/1994.

SARAMAGO, José. História do cerco de Lisboa.São Paulo, Folha de S.Paulo, 2003. 
SCHILLER, Friedrich J. C. Educação Estética do homem. São Paulo: Iluminuras, 1989.

SOLE, Isabel. Estratégias de leitura. 6aed. Porto Alegre: Artmed, 1998.

TAVARES, Mônica. Por uma tipologia da imagem interativa. $11^{\circ}$ Encontro Anual da Associação Nacional dos Programas de Pós-Graduação em Comunicação - Compós 2002.

TORRINHA, Francisco. Dicionário Latino Português. 6a Ed. Porto: Graficos Reunidos LDA, [194-?]

- Endereços eletrônicos www.ciberpoesia.com.br www.w3haus.com.br http://pensador.uol.com.br/autor/clarice lispector/ www.jornaldepoesia.jor.br www.revistadacultura.com.br 


\section{Anexos}

"Semeando Sonhos"
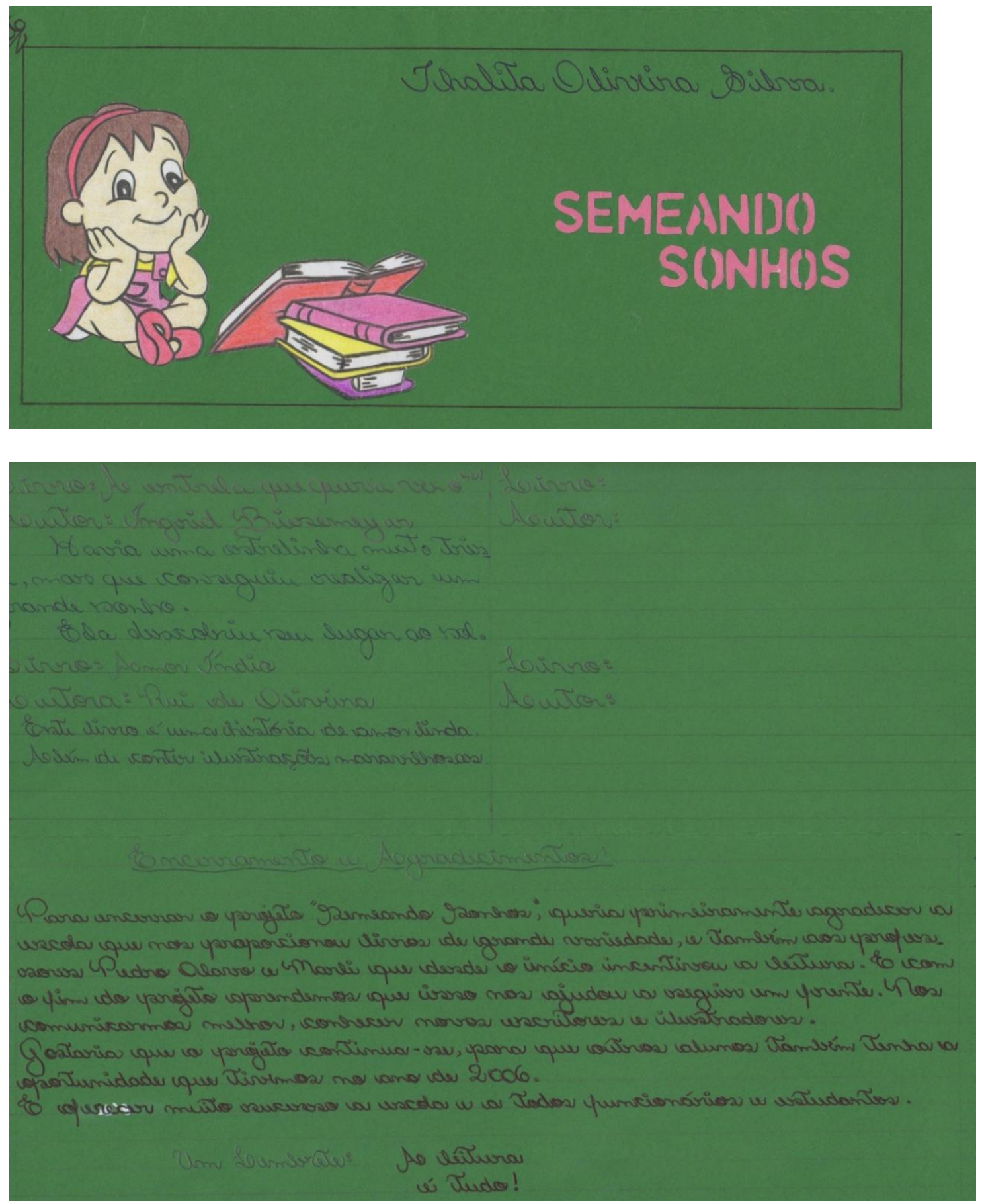


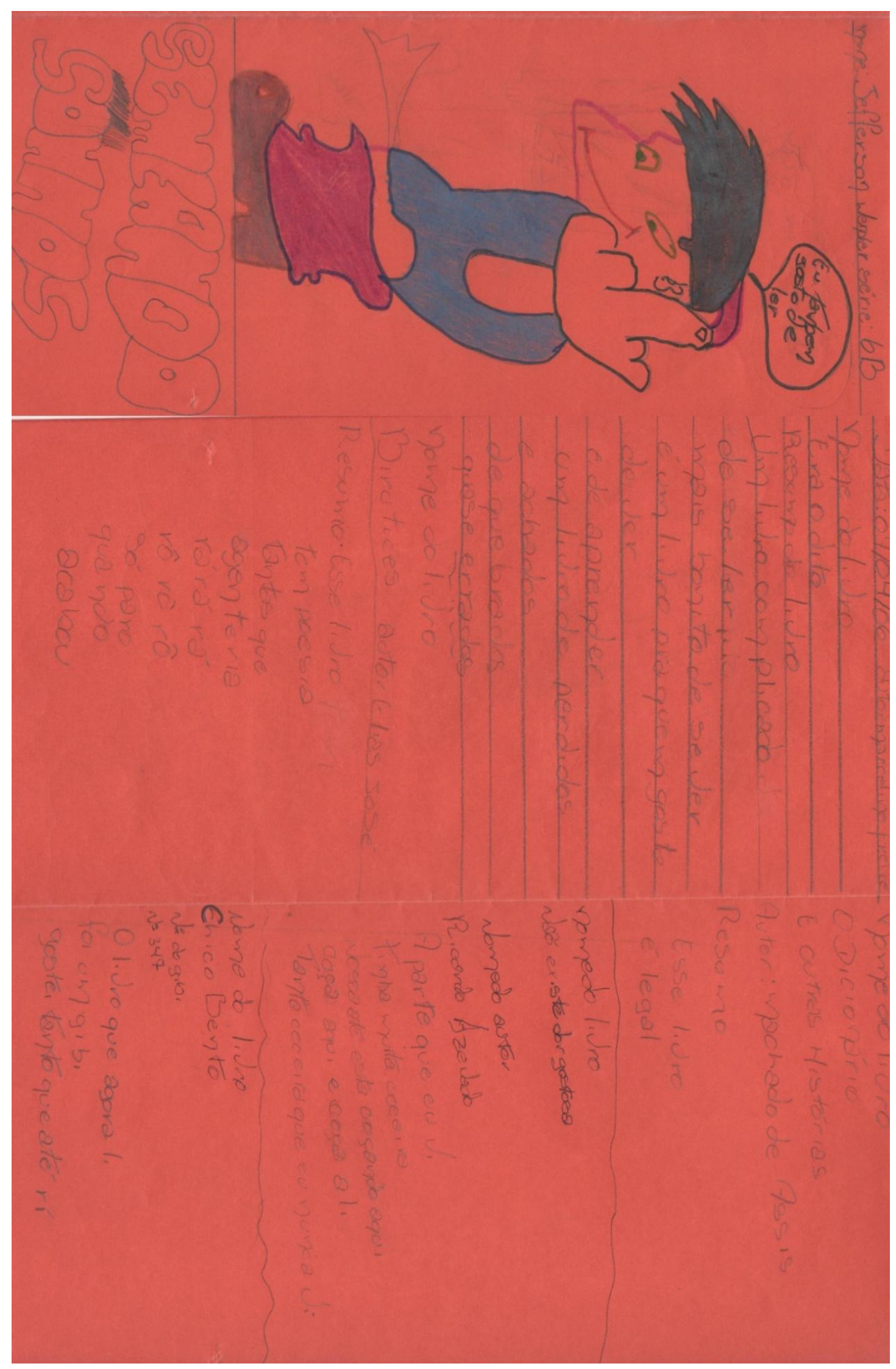


"Café com Poesia

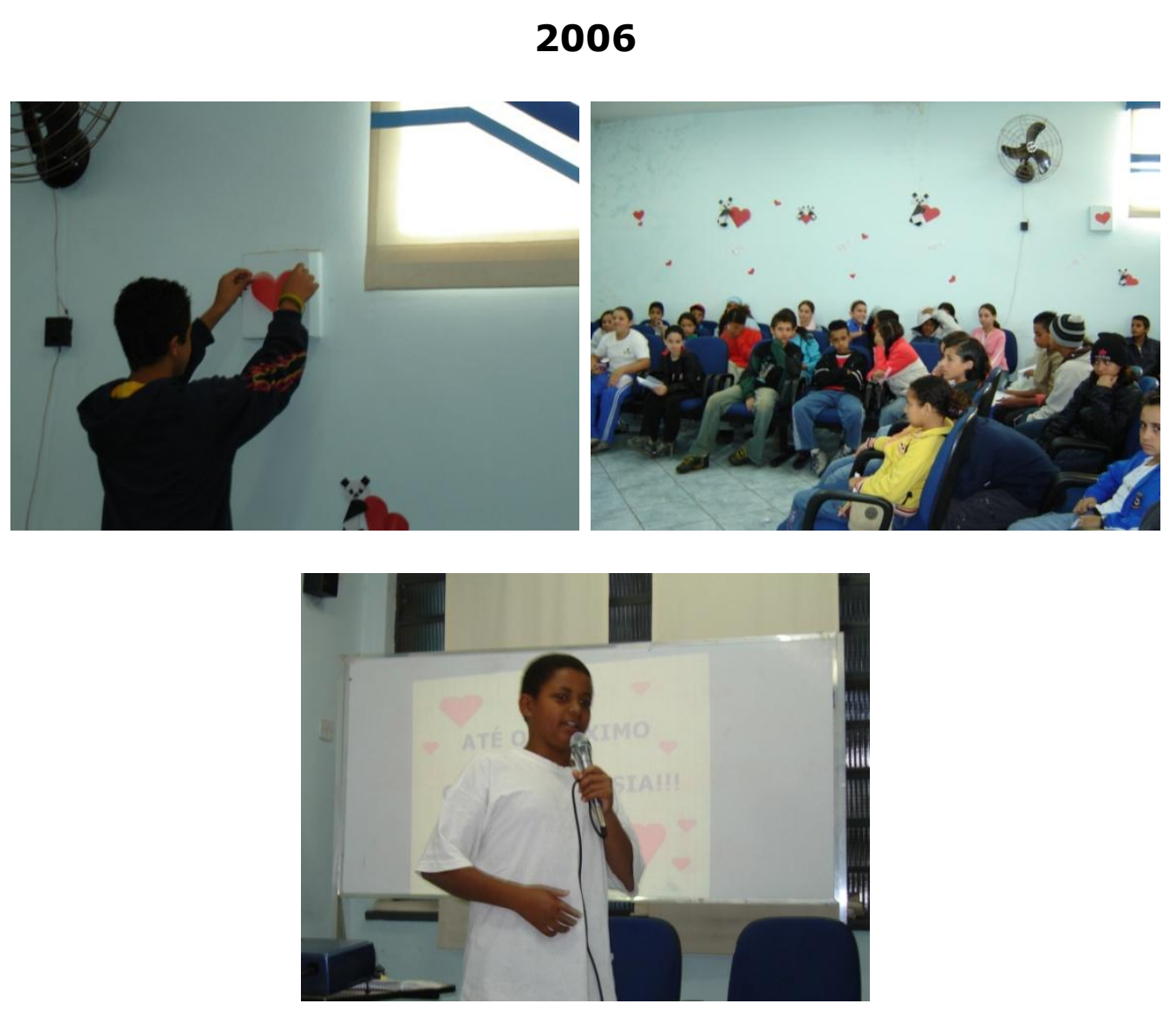

2007
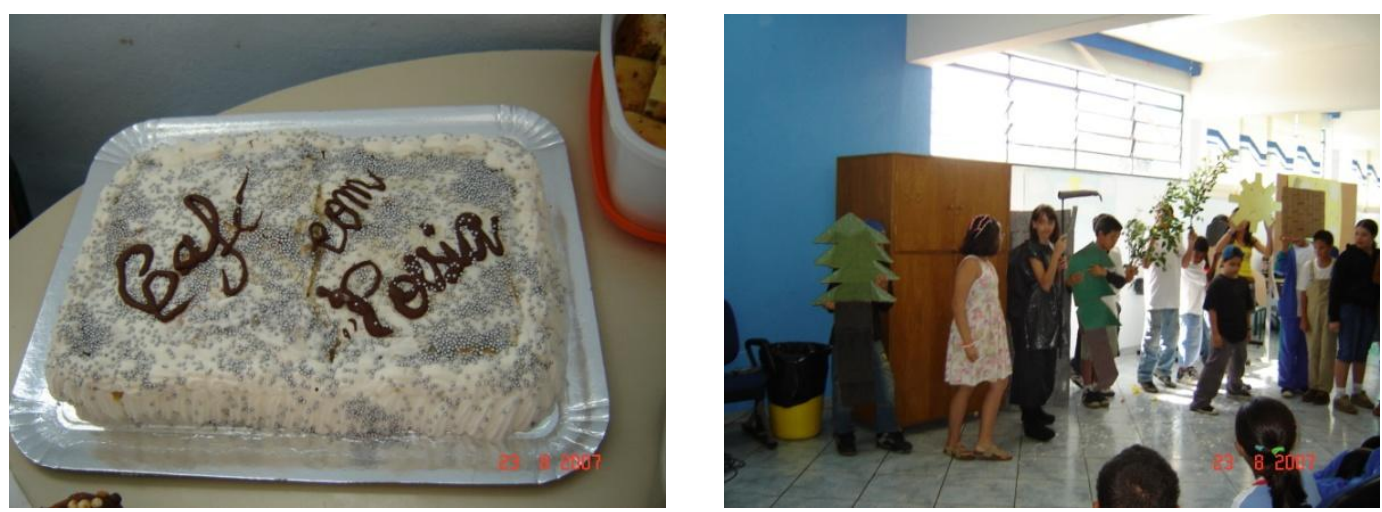

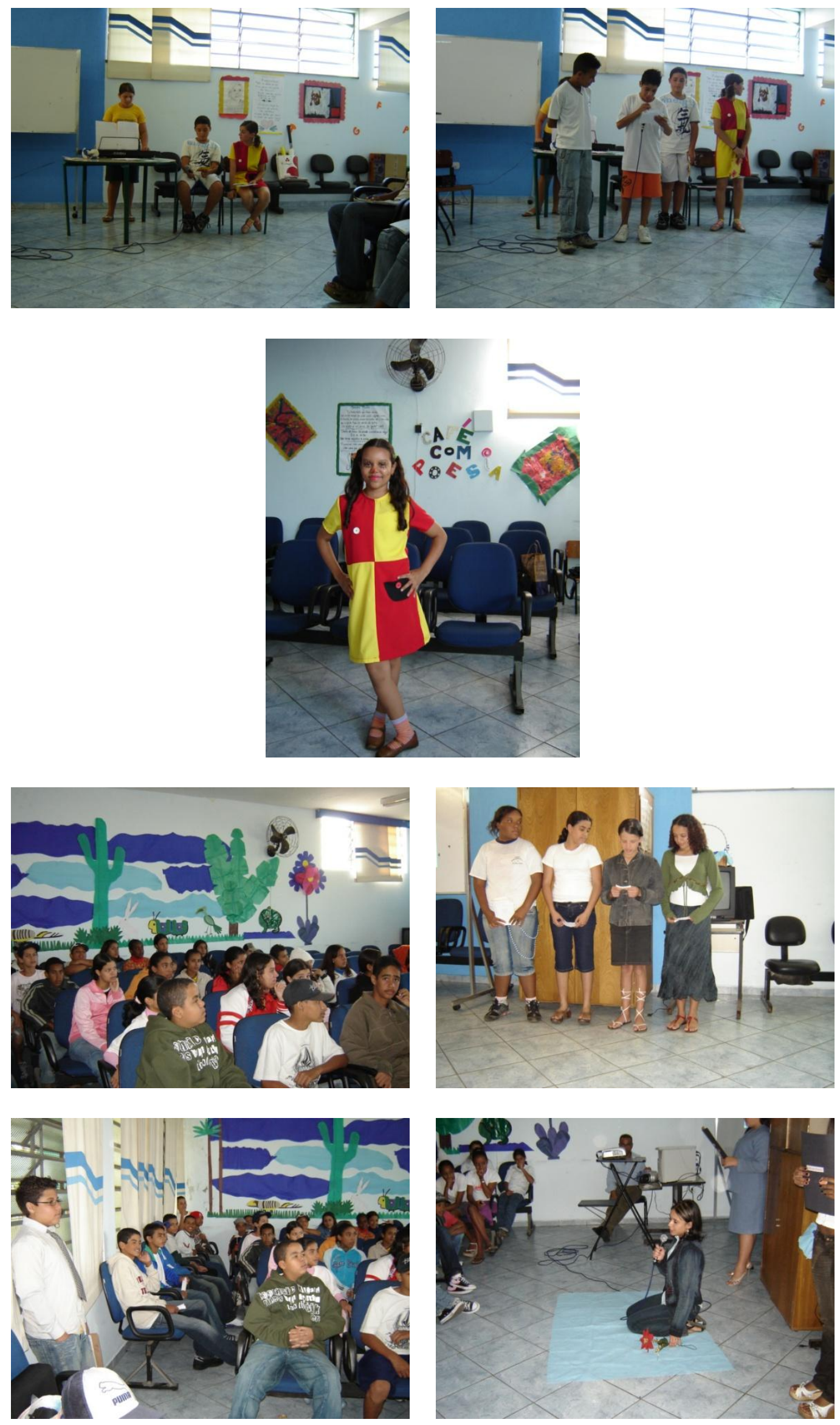
TABULAÇÃO GERAL DA PESQUISA - 6ªA,B,C,D e E / 2006

Total: 144 alunos pesquisados

1 - Você gosta de ler?

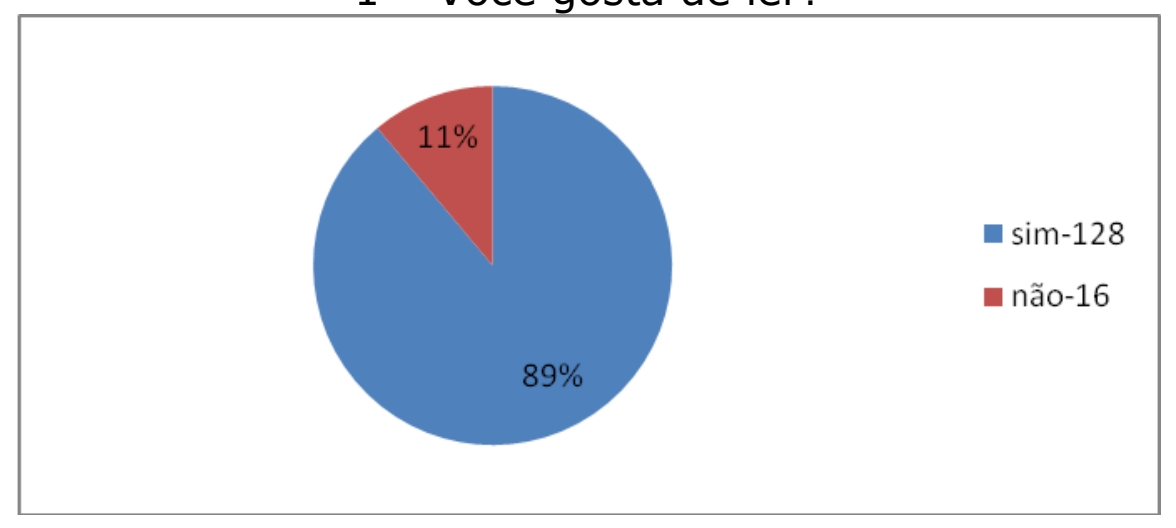

2 - Você lê em casa?

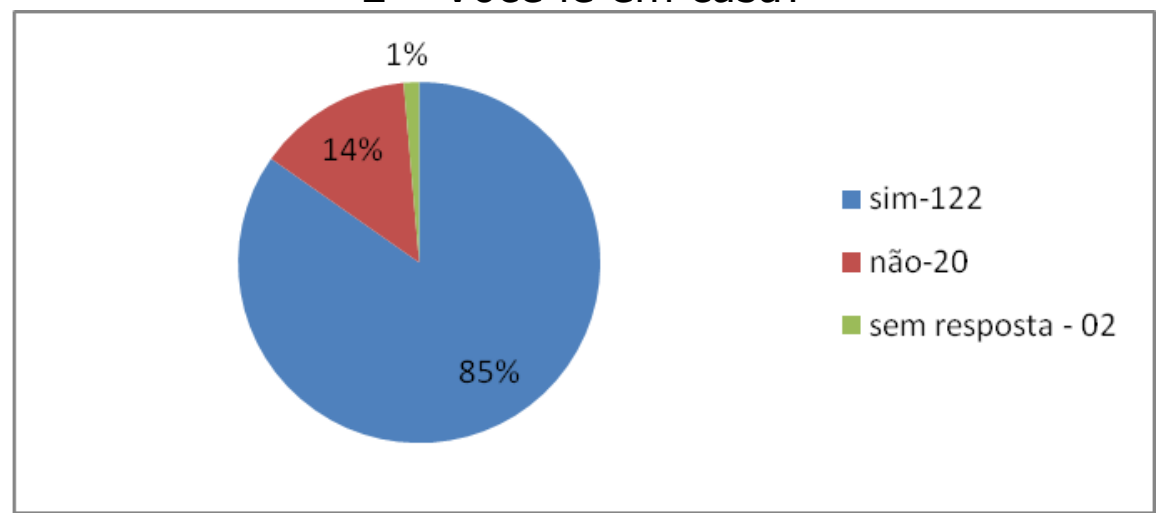

3 - Na sua casa tem:

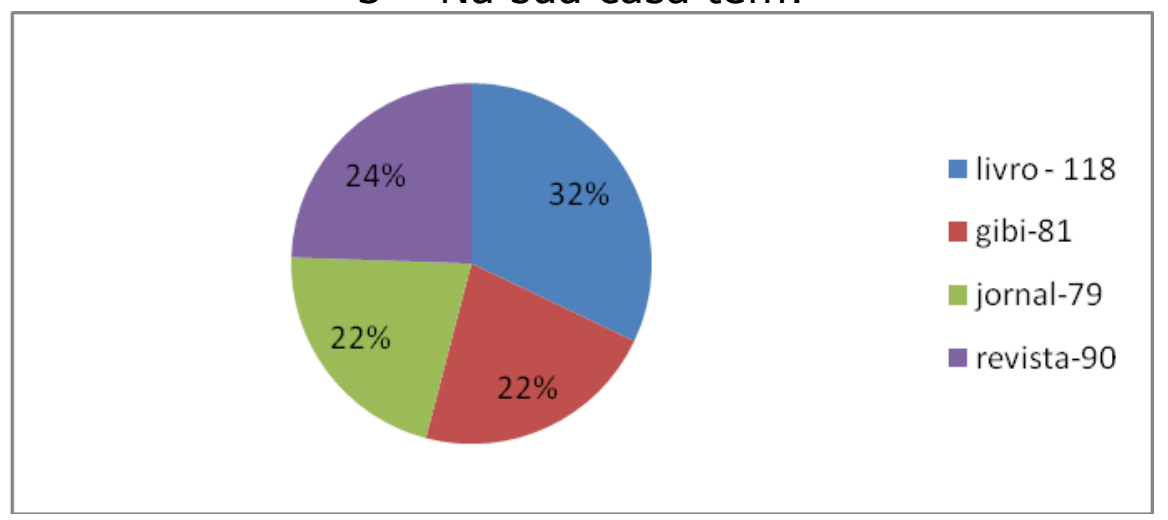




\section{4 - Que tipo de leitura você faz?}

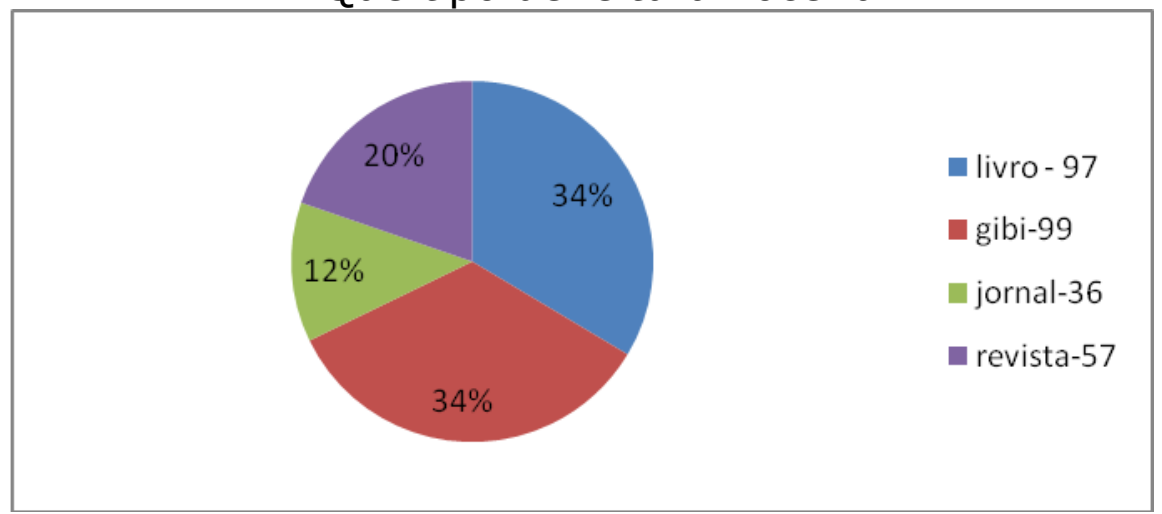

5 - Você gosta de histórias:

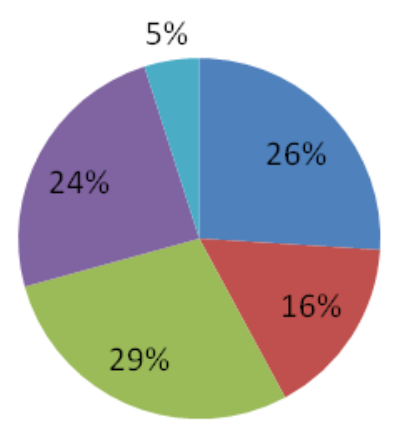

amor-79

morte-49

terror-87

humor-74

outros-15

\section{6 - Você prefere livros com:}

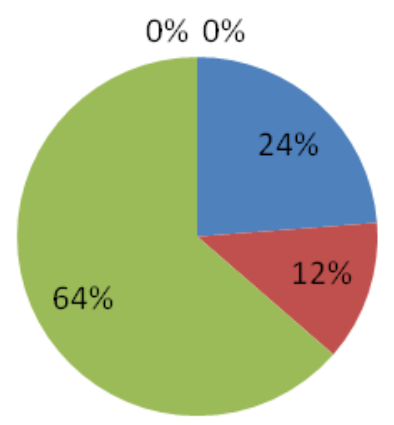

mais figuras do que palavras-34

mais palavras do que figuras-18

figuras e palavras de forma proporcional-91

7 - Você gosta de textos:

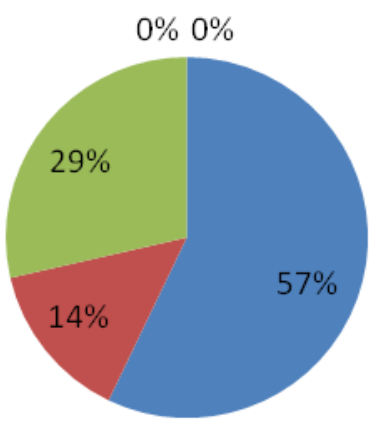

- poéticos/literários 104

a jornalísticos - 26

científicos - 52 
8 - Você acha a leitura importante na sua vida? Por quê? (resposta dissertativa)

Nessa resposta foi interessante observar como os adolescentes dão importância à leitura, de várias formas diferentes: utilitária "porque sem a leitura você pode se perder. Ex.: se você está em um ponto de ônibus e quer ir para o bairro Jardim dos Ypes mas no ônibus está escrito Mogi Mirim, você se perde" ou "sem a leitura nós não saberíamos o nome das coisas, não existiriam livros, gibis, jornais, textos, etc. e como existiria escola sem leitura?"; desenvoltura "eu fico nervoso quando leio em público e gaguejo, treinando a leitura posso melhorar" ou "quanto mais você lê, você vai melhorando cada vez mais para quando for fazer uma palestra, reunião, etc., você vai ser mais aplicado"; perspectiva "a leitura ajuda a lermos melhor, e no futuro fazermos uma faculdade boa e melhor" ou "porque a maioria dos empregos exigem os estudos e a leitura"; prazer, ascensão "é muito boa, você fica mais culta e é muito bom quando você está chateada, aquela de humor" ou "a leitura desenvolve nossa mente e refresca".

As perguntas deste questionário foram elaboradas para verificarmos qual a relação dos alunos com a leitura, se eles consideravam-na parte da vida deles ou apenas uma necessidade escolar.

Pode-se notar que tanto nas respostas de alternativa ou dissertativa, a maioria dos alunos demonstrou que além do gosto pela 
leitura, sabiam da importância dela em suas vidas. Interessante notar que mesmo os alunos com muita dificuldade de leitura, tiveram opiniões semelhantes aos que liam com maior fluência. Diante dessa constatação, nossos projetos puderam ser melhor planejados e desenvolvidos. 